NIST Special Publication 500-304

\title{
Conformance Testing Methodology Framework for ANSI/NIST-ITL 1- 2011 Update: 2013, Data Format for the Interchange of Fingerprint, Facial \& Other Biometric Information
}

Christofer J. McGinnis

Dylan J. Yaga

Fernando L. Podio

This publication is available free of charge from: http://dx.doi.org/10.6028/NIST.SP.500-304

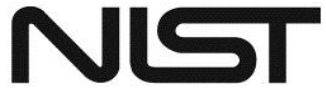

National Institute of Standards and Technology

U.S. Department of Commerce 


\section{NIST Special Publication 500-304}

\section{Conformance Testing Methodology Framework for ANSI/NIST-ITL 1- 2011 Update: 2013, Data Format for the Interchange of Fingerprint, Facial \& Other Biometric Information}

Christofer J. McGinnis

Dylan J. Yaga

Fernando L. Podio

Computer Security Division Information Technology Laboratory

This publication is available free of charge from: http://dx.doi.org/10.6028/NIST.SP.500-304

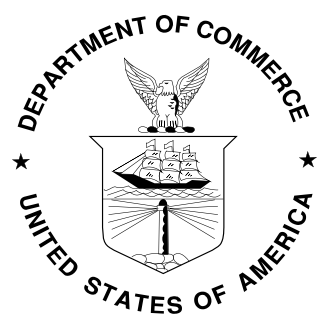

U.S. Department of Commerce Penny Pritzker, Secretary 
Certain commercial entities, equipment, or materials may be identified in this document in order to describe an experimental procedure or concept adequately. Such identification is not intended to imply recommendation or endorsement by the National Institute of Standards and Technology, nor is it intended to imply that the entities, materials, or equipment are necessarily the best available for the purpose.

National Institute of Standards and Technology Special Publication 500-304 Natl. Inst. Stand. Technol. Spec. Publ. 500-304, 75 pages (June 2015)

CODEN: NSPUE2

This publication is available free of charge from: http://dx.doi.org/10.6028/NIST.SP.500.304 


\section{Reports on Information Technology}

The Information Technology Laboratory (ITL) at the National Institute of Standards and Technology (NIST) stimulates U.S. economic growth and industrial competitiveness through technical leadership and collaborative research in critical infrastructure technology, including tests, test methods, reference data, and forward-looking standards, to advance the development and productive use of information technology. To overcome barriers to usability, scalability, interoperability, and security in information systems and networks, ITL programs focus on a broad range of networking, security, and advanced information technologies, as well as the mathematical, statistical, and computational sciences. Special Publication 500-series reports on ITL's research in tests and test methods for information technology, and its collaborative activities with industry, government and academic organizations.

This publication is a contribution of the National Institute of Standards and Technology and is not subject to copyright. Any organization interested in reproducing "Conformance Testing Framework for ANSI/NIST-ITL 1-2011 Update 2013, Data Format for the Interchange of Fingerprint, Facial \& Other Biometric Information" is free to do so. However, there shall be no alteration to any of the material information contained in the publication. NIST retains the sole right to submit this publication to any other forum for any purpose.

Certain commercial entities, equipment, or materials may be identified in this document in order to describe an experimental procedure or concept adequately. Such identification is not intended to imply recommendation or endorsement by the National Institute of Standards and Technology, nor is it intended to imply that the entities, materials, or equipment are necessarily the best available for the purpose.

National Institute of Standards and Technology

Special Publication 500-304

Natl. Inst. Stand. Technol.

75 pages 


\section{Foreword}

The existence of biometric standards alone is not enough to demonstrate that products meet the technical requirements specified in the standards. Conformance testing captures the technical description of a specification and measures whether an implementation faithfully implements the specification. Conformance testing provides developers, users, and purchasers with increased levels of confidence in product quality and increases the probability of successful interoperability. Lack of conformance to the required standard(s) can, in many cases, jeopardize the expected biometric recognition performance or prevent access to the data (as well as impact the overall operational performance) since implementers may handle non-conformant records in different ways during processing.

Although no conformance test can be comprehensive enough to test all the different combinations of mandatory requirements of a standard and all possible combinations of conditional and optional characteristics that could be included in American National Standards Institute (ANSI)/NIST-ITL 2011 Update: 2013 (AN-2013) transactions, a well-designed conformance test tool that faithfully implements a standard conformance testing methodology could raise the level of confidence on the test results. Therefore, transactions tested with such a tool (and reported to be conformant to the standard), are more likely to conform to the standard.

The Computer Security Division (CSD) of NIST/ITL supports the development of biometric conformance testing methodology standards and other conformity assessment efforts through active technical participation in the development of biometric standards and associated conformance test architectures and test suites and develops these test tools to support users who require conformance to selected biometric standards and product developers interested in conforming to biometric standards by using the same testing tools available to users. Testing laboratories can also benefit from the use of these test tools. Under the conformance test software called "BioCTS", NIST/ITL CSD develops Conformance Test Architectures (CTAs) and Conformance Test Suites (CTSs) to test implementations of national and international biometric data interchange formats. The initial version of a CTA/CTS designed to test implementations of the ANSI/NIST-ITL 1-2011 Update: 2013 was recently released. These testing tools and related documentation can be found and downloaded at: http://www.nist.gov/itl/csd/biometrics/biocta_download.cfm. 


\section{Table of Contents}

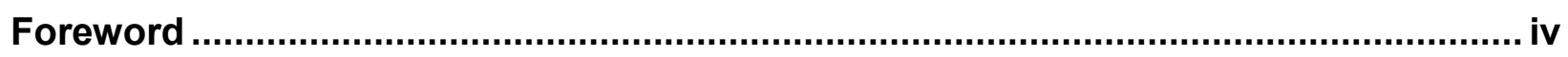

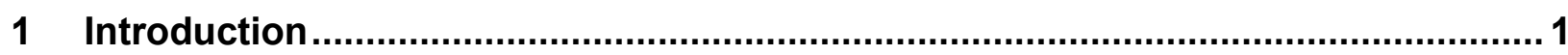

2 Conformance Test Tool Characteristics ............................................................. 2



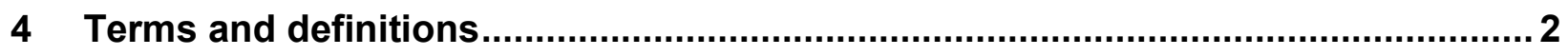

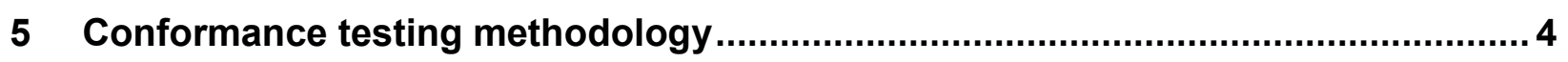

5.1 AN-2013 Requirements and Conformance Test Assertions ................................ 4



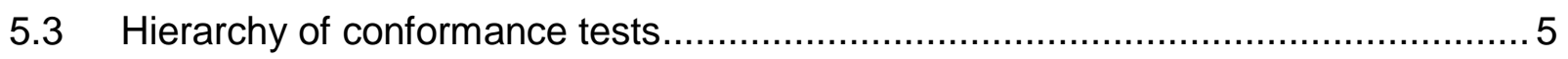

5.4 Functional Documentation of Requirements and Test Assertions ......................... 6

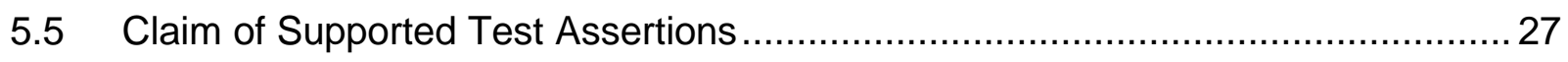

Annex A: Minimum Support for AN-2013 Record Types and Interrelated Fields ........ 29





Annex B: Sample Requirement and Assertion Table Format ..................................... 31

Annex C: Tables of Requirements and Assertions ...................................................... 32








\section{List of Tables and Figures}

Table 5.1 - Assertion Syntax: Value-Type Definitions................................................... 7

Table 5.2 - Assertion Syntax: Defined Values ............................................................. 9

Table 5.3 - Assertion Syntax: Value-based Image Metadata Tags ................................. 10

Table 5.4 - Assertion Syntax: Marker-based Image Metadata Tags.............................. 12

Table 5.5 - Assertion Syntax: Expression Definitions ............................................... 13

Table 5.6 - Assertion Syntax: Complex Expression Definitions ................................. 22

Table 5.7 - Assertion Syntax: Complex Value-Type Definitions.................................. 23

Table 5.8 - Assertion Syntax: Complex Procedure Definitions ................................... 23

Figure 5.9 - Generic AN-2013 Field Structure ........................................................ 24

Table A.1 - AN-2013 Interrelated Field Support .......................................................... 29

Figure B.1 - Sample Requirements and Assertions Table ........................................... 31

Table C.1 - Assertions for Transaction-related Requirements..................................... 33

Table C.2 - Assertions for Record Type 1: Transaction information record ............... 40 


\section{Introduction}

This publication defines a conformance testing methodology framework (CTMF) which includes elements of a conformance testing methodology (CTM), conformance test assertions, and conformance test procedures applicable to ANSI/NIST-ITL 2011 Update: 2013 (AN-2013). It discusses three levels of conformance testing (Level 1, Level 2, and Level 3) and provides a detailed Test Assertion Syntax for describing conformance test procedures. The Conformance Test Assertion Syntax formalizes a method for representing these conformance tests using Expressions, ValueTypes, Operators, and Operands.

A table-based format for documenting AN-2013 requirements and conformance test assertions is included. The table-based format indicates the association between requirements in AN-2013 and the test assertions and test procedures required to test each assertion. It includes information on the applicability of each test assertion indicating whether it only applies to the Traditional encoding as described in Annex B of AN-2013 ("T"), to the National Information Exchange Model (NIEM)conformant Extensible Markup Language (XML) encoding as described in Annex C of AN-2013 ("X"), or to both Traditional and NIEM (XML) encoding ("B").

AN-2013 specifies a data-interchange transaction format comprised of Record Types (collections of biometric and/or forensic modality data and related metadata). The test assertion tables included in Annex $\mathrm{C}$ identify requirements and assertions that are required for every transaction (regardless of its containing Record Types) according to the terms specified in AN-2013. These types of requirements are referred to as transaction-related requirements and are defined as requirements that are not related to a specific Record Type. Examples of transaction-related requirements include:

- The transaction adheres to its specified encoding (Traditional or NIEM-XML) requirements.

- The transaction includes one and only one Record Type-1.

- Record Type-1 is encoded exclusively in 7-bit ASCII (for Traditional Encoding).

- Record Type-1 is conformant to the requirements specified for its fields, subfields, and information items:

- All mandatory fields, subfields, and information items in Record Type-1 must be present (with data), and the requirements for those entities must be met.

- Optional and dependent fields, subfields, and information items that are present in Record Type-1 must be conformant to the requirements specified for those entities.

- the transaction includes at least one other record of a type other than Record Type-1

- the transaction does not include deprecated or reserved record types or fields.

The test assertions for Record Type- 1 are also documented. The requirements in Annex C are silent regarding requirements for any specific Record Type included in the transaction other than Record Type-1. Tables of AN-2013 requirements and test assertions pertaining to specific Record Types (other than Record Type-1) are not documented in this CTMF document, but plans exist to document them in separate publications (National Institute of Standards and Technology Interagency Reports/NISTIRs).

Annex D includes test notes and test exceptions that apply to requirements and assertions documented in Annex $\mathrm{C}$ as well as test notes and exceptions for those requirements which may be released in separate publications. 
Definitions of Type A and B testing are included in Section 4. Level 1, 2, and 3 testing are discussed in Section 5.3. The tables of requirements and test assertions in this publication address only Level 1 and 2 testing and Type-A testing. Assertions for Type-B testing are not included.

The CTMF does not establish tests of characteristics (i.e., performance, acceptance, security, robustness) of products that generate the AN-2013 transactions.

\section{Conformance Test Tool Characteristics}

AN-2013 conformance test tools that fully implement the CTMF for testing the AN-2013 requirements are expected to implement all the requirements of Section 5, the Conformance Testing Methodology section, including the procedures defined by Level 1 and Level 2 test assertions. Such tools are also expected to be capable of testing AN-2013 implementations against the assertions specified in Annex A for the mandatory requirements in AN-2013 and any requirements associated with Optional entities that are included in the transaction. Although many constructs (such as fields and subfields) specified in the AN-2013 standard are optional, their presence in a specific transaction indicates that the requirements specified for those constructs are mandatory (see "Implementation Required" in the table headers of the Tables of requirements and assertions format in Annex A).

\section{References}

NIST Special Publication 500-290 Version 2 (2013), ANSI/NIST-ITL 1-2011 Update:2013, December 2013, Information Technology: American National Standard for Information Systems Data Format for the Interchange of Fingerprint, Facial \& Other Biometric Information, Incorporating ANSI/NIST 1-2011 Sup:Dental \& ANSI/NIST-ITL 1-2011 Sup:Voice with additional new material Available at http://biometrics.nist.gov/cs_links/standard/ansi_2012/Update-

Final_Approved_Version.pdf

JPEG (Joint Photographic Experts Group), JPEG File Interchange Format, Version 1.02. Available at http://www.jpeg.org/public/jfif.pdf

ISO/IEC 15444-1, JPEG 2000, Information Technology - Digital Compression and Coding of Continuous-Tone Still Images Part 1: Requirements and Guidelines.

ISO/IEC 15444-2, Information technology - JPEG 2000 image coding system: Extension, available at: http://www.jpeg.org/metadata/15444-2.PDF

ISO/IEC 15948:2004 Information Technology -- Computer graphics and image processing -- Portable Network Graphics (PNG): Functional specification.

IAFIS-IC-0110 (V3.1) WSQ Gray-scale Fingerprint Image Compression Specification, October 4, 2010.

\section{Terms and definitions}

\section{AN-2013}

ANSI/NIST-ITL 2011 Update: 2013 


\section{assertion}

A test procedure that represents a specific aspect of a requirement found in the base standard. The assertion is expressed using the test assertion syntax defined by the CTMF.

\section{base standard}

ANSI/NIST-ITL 1-2011 Update: 2013, Data Format for the Interchange of Fingerprint, Facial \& Other Biometric Information, NIST Special Publication 500-290 Version 2 - Incorporating

ANSI/NIST 1-2011 Sup:Dental \& ANSI/NIST-ITL 1-2011 Sup:Voice with additional new material.

\section{conformance}

The adherence of an implementation to all specified requirements as defined in the base standard.

\section{CTA}

Conformance Testing Architecture.

\section{CTM}

Conformance Testing Methodology. A description of the procedures necessary to test an implementation for conformance to the requirements specified in the base standard.

\section{CTMF}

Conformance Testing Methodology Framework. The foundational specification of the format and procedures that must be utilized to properly document and test requirements according to the base standard, and therefore establish a Conformance Testing Methodology.

\section{CTS}

Conformance Testing Suite.

\section{implementation}

A specific AN-2013 transaction.

\section{IUT}

Implementation under test. The implementation supplied by a vendor to a laboratory for conformance testing.

\section{test}

Also known as a conformance test or assertion test, it is the execution of the testing procedure defined by an assertion or set of assertions in order to obtain a statement of conformance. The result of the test is a Boolean value that determines the implementation's conformity for the assertion. For a 
given requirement, if all tests pass for the associated assertions, then the implementation is considered to be conformant for that requirement.

\section{Type-A testing}

Type-A conformance testing checks the conformance of AN-2013 transactions to the requirements in the base standard.

\section{Type-B testing}

Type-B testing checks the ability to use an AN-2013 transaction, for example in a software application.

\section{Conformance testing methodology}

The CTMF addresses only Level 1 and 2 testing and Type-A testing. Annex A lists test assertions for Level-1 and Level-2 requirements. While Level-3 requirements may be identified in Annex A, no related test assertions are documented (see "Hierarchy of conformance tests" for information regarding the three levels of conformance testing). Type-B testing is not addressed.

\subsection{AN-2013 Requirements and Conformance Test Assertions}

Tables of AN-2013 requirements and conformance test assertions are documented in this publication and included in Annex A. AN-2103 transaction-related requirements (defined as requirements that are not related to a specific Record Type) as well as AN-2013 requirements and test assertions for Record Type 1 are included. The tables provide the information necessary to facilitate the development of conformance test assertions and testing tools. Each AN-2013 requirement identified in this publication is associated with one or more specified test assertions which collectively expect to form the complete set of procedures required to test an implementation for conformance to that requirement. More details on these types of test assertions are included below:

- Transaction-related Requirements and Associated Test Assertions Table

Includes AN-2013 requirements and associated test assertions related to all AN-2013 transactions, their data conventions, encodings, content, and other information not related to a specific Record. Examples include requirements and associated test assertions that describe (and document how to test) the structure and ordering of constructs that make up all AN-2013 transactions; nonexistence checks for deprecated Record Types 3, 5, and 6 as well as reserved Record Types 22 through 97; and requirements defined in Annex B, C, and G of AN-2013 related to AN-2013 transactions.

- Record Type-1: Transaction Information Record Requirements and Associated Test Assertions

Includes AN-2013 requirements and test assertions related to mandatory fields, subfields, information items, and XML Elements in Record Type-1 that must be met for every AN-2013 transaction; optional constructs for Record Type-1 (if any optional construct is present in a transaction, the defined requirements for those constructs become mandatory); and those related 
to testing that one and only one instance of Record Type-1 is present in every AN-2013 transaction.

\subsection{Limitations and exceptions}

Section 1 describes the AN-2013 requirements that are documented with the associated required test assertions. Complementary publications are planned to be released which will document AN-2013 requirements and test assertions for specific AN-2013 Record Types in a format that complies with the CTMF described in this publication. A comprehensive AN-2013 CTMF (for testing all Record Types specified in the AN-2013 standard) would consist of the methodology documented in this publication as well as the set of requirements and assertions for each Record Type in AN-2013.

While conformance of an implementation to all relevant requirements can be determined, no test tool is guaranteed to be comprehensive and prove that a given system generating or using AN-2013 transactions is conformant under all possible circumstances. Well-designed conformance tests can, however, test the most likely sources of problems and demonstrate non-conformity (i.e., if errors are found, non-conformance of the transaction is likely), but the absence of detected errors does not necessarily imply full conformance to the standard.

\subsection{Hierarchy of conformance tests}

Three levels of conformance testing are briefly described. For each assertion included in the tables of requirements and assertions, a level of conformance testing is indicated.

\section{Level 1 conformance testing}

Level 1 conformance testing deals with the form and structure of the internal content and verifies that data structures exist and have allowable values. Specifically, it checks for the presence, structure, and value of each field, subfield, and information item in a transaction for conformance with the specification of the standard, both in terms of ranges and cardinality. Since Level 1 testing can be performed by a simple field-by-field reading of the standard and comparison to known values and their encoding, only the AN-2013 transactions are required for conformance testing, and no hardware or software components are used to create those transactions.

\section{Level 2 conformance testing}

Level 2 conformance testing deals with explicit requirements that check for internal consistency. Specifically, morphological conformance checks the relationships between fields, subfields, or information items within a transaction, including comparisons of values, as specified in the AN-2013 standard. Level 2 tests involve interactions between multiple values from different parts of the standard and sometimes from implicit observations that are not explicitly stated in the base standard. Thus, Level 2 tests require more complex validation than Level 1. Similar to Level 1 testing, Level 2 conformance testing only requires an AN-2013 transaction(s).

\section{Level 3 conformance testing}


Level 3 conformance testing checks if the biometric transaction is a faithful representation of the parent biometric data and ensures requirements are satisfied that are not merely Level 1 and Level 2 tests. Individual fields may have explicit semantic requirements for which conformance testing is significantly difficult or even impossible to test. Unlike Level 1 and Level 2 testing, Level 3 testing may require software and hardware components used to create the AN-2013 transactions, and may also require the subject and samples from which the biometric information stored in the transaction was collected. The requirements and assertion tables indicate whether Level 1 or Level 2 conformance testing is required to address the assertion identified in the test assertion. Required Level 3 conformance tests are not performed but they may be identified in the tables to indicate that the requirement is not addressed or that it is not currently testable.

\section{XML Schemas and Conformance Testing}

This CTMF, where possible, leverages the conformance-related information contained in the XML Schemas specified within the AN-2013 standard; however, the XML Schemas are only part of the overall testing. Section C.5.1 in the ANSI/NIST-ITL 1-2011 Update: 2013 standard specifies: To the extent possible, the schema defines data types and constraints that enforce the allowable content rules of the base standard. Nevertheless, the XML schema may not strictly enforce the allowable content. The base standard defines allowable content, and its requirements shall be met by implementers regardless of encoding method.

Careful analysis of the XML Schemas, distributed on the ANSI/NIST-ITL Homepage Website, reveal discrepancies between the XML Schema requirements and the AN-2013 standard requirements:

- Level 1 conformance testing - Not all allowable values have been specified within the XML Schema files.

- Level 2 conformance testing - Many interrelationship, internal consistency, and interaction tests between multiple values from different sections of a transaction are incapable of being specified within the XML Schemas.

The XML Schema files may not strictly enforce the allowable content in two ways:

- By Being Overly Broad - Which allows for the testing of more values than the allowable values as specified in the AN-2013 standard requirements. If this is the case, there are additional Assertions specified in this CTMF to test for the actual range of values.

- By Preventing Requirements - This case is when the XML Schema explicitly prevents base requirements specified in the AN-2013 standard from being tested. If this is the case the only option is to modify the XML Schema files. This modified Schema file is not included in this CTMF, but will be documented separately and made available at: http://www.nist.gov/itl/csd/biometrics/biocta_download.cfm.

\subsection{Functional Documentation of Requirements and Test Assertions}

This section defines the syntax and format required to explicitly identify and document AN-2013 requirements and conformance test assertions in a concise manner that conveys the necessary information for conformance testing.

Test Assertion Syntax 
Test Assertions represent the set of tests performed to determine conformance for a specific Requirement specified in AN-2013. The Test Assertion Syntax described in this section formalizes a method for representing these conformance tests using Expressions, Value-Types, Operators, and Operands to describe Test Assertions.

In some instances, a Test Assertion cannot be clearly or easily represented using this syntax. These cases are referred to as Complex Assertions and English is used to express the assertion in the following format: Complex (Description), where Description is a summary of the Test Assertion. Additional syntax is described for use in complex Test Assertions only to help clarify their meaning.

\section{Test Assertions}

Test Assertions are evaluated to obtain a Test Result, which may be Pass, Fail, or Warning. Pass indicates the likelihood that the implementation conforms to that specific requirement, while Fail indicates again the likelihood that the implementation does not meet that specific requirement in the standard. Warning indicates that no errors were detected but provides additional information useful for the implementer.

Test Assertions are made up of one or more Expressions as defined in the Expression Definitions table. The outermost Expression in any Test Assertion must return a Boolean or Test Result value as defined in the Value-Type Definitions table. If the outermost Expression returns a Boolean, it is converted to a Test Result in the following manner: True becomes Pass, and False becomes Fail.

\section{Value Types}

The following table lists the Value Types that may be used in the Expressions that make up the Assertion Syntax. The actual value, represented by VALUE in the table, is contained in parentheses just after the Value Type identifier. Value Types differ from Expressions, because Value Types cannot accept any operands; they accept only the defined values specified in the Valid Values column. For example, Int(-1) is the Integer value negative one.

Due to the nature of AN-2013 transactions which may include multiple instances of each record type other than Type-1, any specified entity Value Type is not necessarily unique. For example, Fld(10.001) represents every occurrence of Field 1 in any Record Type-10.

\section{Table 5.1 - Assertion Syntax: Value-Type Definitions}

\begin{tabular}{|c|c|c|}
\hline \multicolumn{3}{|c|}{ Value-Type Definitions } \\
\hline Value Type & Valid Values & Syntax \\
\hline Boolean & True, False. & Bool(VALUE) \\
\hline Numeric & 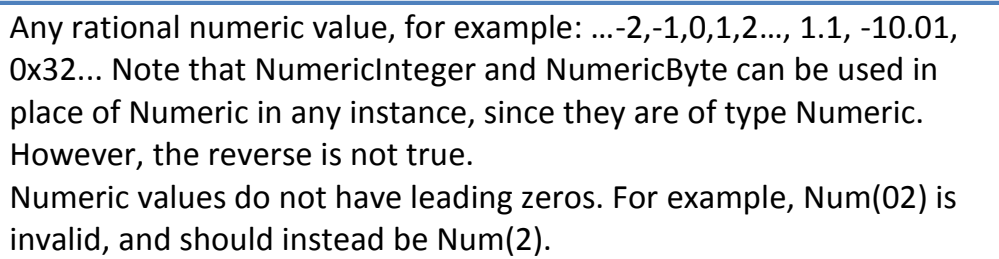 & Num(VALUE) \\
\hline
\end{tabular}




\begin{tabular}{|c|c|c|}
\hline NumericInteger & Any Integer Value: ...-2,-1,0,1,2..., & Int(VALUE) \\
\hline NumericByte & $\begin{array}{l}\text { One byte of binary data, represented in Hex. The value is represented } \\
\text { using " } 0 x \text { ". For example: } 0 \times 30\end{array}$ & Byte(VALUE) \\
\hline String & 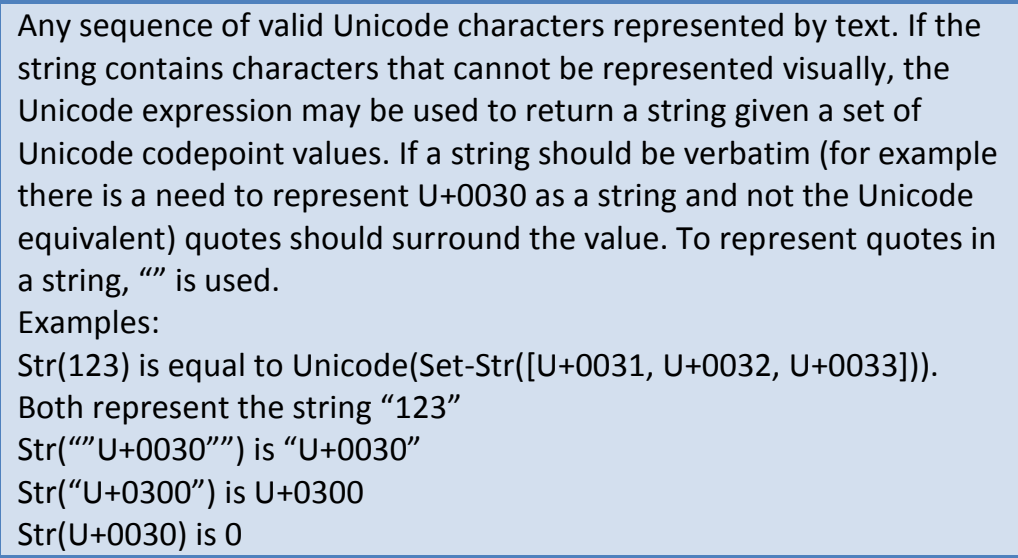 & Str(VALUE) \\
\hline StringList & $\begin{array}{l}\text { A list of valid String Value-Types separated by the | character in the } \\
\text { form: firstValue } \mid \text { secondValue } \mid . . . \\
\text { Examples: } \\
\text { StrList(This is } \mid \text { a } \mid \text { List) } \\
\text { StrList(Unicode }(U+001 C)|1| 2 \mid \text { Unicode(Set-Str([U+001E,U+001F]))) }\end{array}$ & StrList(VALUE) \\
\hline Set & $\begin{array}{l}\text { Any set of values included in the [] characters. The comma is used to } \\
\text { separate values. The "to" term is used to represent a range for } \\
\text { Integer Numeric types. For example, } \\
\text { Set-Num([0,2, } 5 \text { to } 100]) \text {, Set-Str([A, B, C, Alfa, Bravo, Charlie]), Set- } \\
\text { Fld([1.001, } 1.002 \text { to } 1.005]), \text { Set-Byte([0x00, 0xFF]) } \\
\text { Note that for sets of Strings, the comma is reserved as a separator } \\
\text { between values. To represent a comma in a Set-Str, use U+002C. }\end{array}$ & $\begin{array}{l}\text { Set-TYPE(VALUE), } \\
\text { where TYPE is any of } \\
\text { the Value-Type } \\
\text { Syntax } \\
\text { representations. }\end{array}$ \\
\hline EntityTransaction & The transaction that contains all other entities in the file. & Transaction \\
\hline EntityRecord & $\begin{array}{l}\text { A Record represented by the numeric value of the Record Type. } \\
\text { Ex: } \operatorname{Rec}(10) \text { is Record Type- } 10 .\end{array}$ & Rec(VALUE) \\
\hline EntityField & $\begin{array}{l}\text { The Field represented by the string in the form: RT.FN } \\
\text { RT is Record Type, FN is Field Number } \\
\text { Ex: } 10.998 \text { is Field } 998 \text { in Record Type-10 }\end{array}$ & Fld(VALUE) \\
\hline EntitySubField & $\begin{array}{l}\text { The Subfield represented by the string operand in the form: RT.FN.SI } \\
\text { RT is Record Type, FN is Field Number, } \mathrm{SI} \text { is the Subfield Index. } \\
\text { If no } \mathrm{SI} \text { is specified, then this refers to any Subfield in the Field. } \\
1.003 .1 \text { is Subfield } 1 \text { in Field } 1.003 \text {, } \\
1.003 \text { is each Subfield in Field } 1.003 \text {; this is useful when subfields are } \\
\text { unbounded, so that an assertion may address each subfield without } \\
\text { knowing the number of subfields that will be present. }\end{array}$ & SUbF(VALUE) \\
\hline EntityInfoItem & $\begin{array}{l}\text { The Information Item represented by the string in the form: RT.FN.IM } \\
\text { RT is Record Type, FN is Field Number, IM is Infoltem Mnemonic } \\
\text { Ex: 1.003.IDC is Info Item IDC in Field } 1.003\end{array}$ & Infol(VALUE) \\
\hline EntityElement & $\begin{array}{l}\text { XML Element with name indicated by the string in the form: RT.FN.XN } \\
\text { RT is Record Type, FN is Field Number, XN is the Xml element name } \\
\text { Ex:1.002.biom:TransactionMajorVersionValue }\end{array}$ & XEIm(VALUE) \\
\hline EntityContainerElement & $\begin{array}{l}\text { XML Container Element (has no Field Number, and is only used to } \\
\text { organize other Xml Elements) indicated by the string in the form: } \\
\text { RT.XN } \\
\text { RT is Record Type, FN is Field Number, XN is the Xml element name } \\
\text { Ex: XEImC(10.biom:Facelmage) }\end{array}$ & XCont(VALUE) \\
\hline
\end{tabular}


In order to decrease redundancy, predefined values are listed here and used multiple times throughout the tables of requirements and assertions.

Table 5.2 - Assertion Syntax: Defined Values

\begin{tabular}{|c|c|c|}
\hline \multicolumn{3}{|c|}{ Defined Values } \\
\hline Defined Value & Containing Values & Notation \\
\hline Integer Set & $\begin{array}{l}\text { Set of all Integers (positive and negative integral values, including zero) } \\
\text { represented as a Set-Int. }\end{array}$ & Integers \\
\hline $\begin{array}{l}\text { Numeric } \\
\text { Leading Zero }\end{array}$ & $\begin{array}{l}\text { The string value is a Regular Expression in the form: } \\
\text { Str(^ }(\backslash+|-|\{0,1\} 0([0-9]+\mid[0-9]+\backslash \cdot[0-9]+) \$ \text { ) } \\
\text { The expression represents any numeric value (with or without a }+ \text { or }- \text { sign) that } \\
\text { has a leading zero followed by one or more numeric digits (which optionally may } \\
\text { be followed by a decimal point and one or more numeric digits after the } \\
\text { decimal). }\end{array}$ & $\begin{array}{l}\text { LeadingZer } \\
\text { oNum }\end{array}$ \\
\hline Time Index & $\begin{array}{l}\text { The string value is a Regular Expression in the form: } \\
\text { Str }(\wedge([0,1][0-9] \mid 2[0-3]):[0-5][0-9]:[0-5][0-9] \cdot[0-9]\{3\} \$ \text { ) } \\
\text { The expression represents time in the form hh:mm:ss.nnn, where hh is the two- } \\
\text { digit hour,mm is the two-digit minute, ss is the two-digit seconds, and nnn is the } \\
\text { three-digit milliseconds. (See section 7.7.2.5 of the standard). }\end{array}$ & $\begin{array}{l}\text { ValidTimel } \\
\qquad \mathrm{dx}\end{array}$ \\
\hline $\begin{array}{l}\text { Date Range } \\
\text { Estimate }\end{array}$ & $\begin{array}{l}\text { The string expression is a Regular Expression in the form: } \\
\wedge((Y[0-9]\{1,2\})\{0,1\}(M[0-9]\{1,2\})\{0,1\}(D[0-9]\{1,2\})\{0,1\}) \$ \\
\text { The expression represents the amount of time used as an offset (plus or minus), } \\
\text { in the form YyyMmmDdd . Any of Yyy, Mmm, or Ddd may be omitted. Bold } \\
\text { letters are constants; yy is the 2-digit year offset, } \mathrm{mm} \text { is the 2-digit month offset, } \\
\text { and dd is the 2-digit day offset. The bold letters are constants. }\end{array}$ & $\begin{array}{l}\text { DateRange } \\
\text { Estimate }\end{array}$ \\
\hline $\begin{array}{l}\text { Date Time } \\
\text { Range Estimate }\end{array}$ & $\begin{array}{l}\text { The string expression is a Regular Expression in the form: } \\
\wedge((\mathrm{Y}[0-9]\{1,2\})\{0,1\}(\mathrm{M}[0-9]\{1,2\})\{0,1\}(\mathrm{D}[0-9]\{1,2\})\{0,1\}(\mathrm{h}[0-9]\{1,2\})\{0,1\}(\mathrm{m}[0- \\
9]\{1,2\})\{0,1\}) \$ \\
\text { The expression represents the amount of time used as an offset (plus or minus), } \\
\text { in the form YyMmmDddhhhmmm. Any of Yyy, Mmm, Ddd, hhh, or } \mathbf{m m m} \text { may } \\
\text { be omitted. The bold letters are constants. }\end{array}$ & $\begin{array}{l}\text { DateTimeR } \\
\text { angeEstima } \\
\text { te }\end{array}$ \\
\hline $\begin{array}{l}\text { Numeric } \\
\text { Characters }\end{array}$ & Set-Str($([0,1,2,3,4,5,6,7,8,9])$ & CharNum \\
\hline $\begin{array}{l}\text { Alphabetic } \\
\text { Characters }\end{array}$ & $\begin{array}{l}\text { Set-Str } \\
([A, B, C, D, E, F, G, H, I, J, K, L, M, N, O, P, Q, R, S, T, U, V, W, X, Y, Z, a, b, c, d, e, f, g, h, I, j, k, l, l, m, n, o, p, \\
q, r, s, t, u, v, w, x, y, z])\end{array}$ & CharAlpha \\
\hline $\begin{array}{l}\text { Alphanumeric } \\
\text { Characters }\end{array}$ & $\begin{array}{l}\text { Set-Str ([0,1,2,3,4,5,6,7,8,9,A,B,C,D,E,F,G,H,I,J,K,L,M,N,O,P,Q,R,S,T,U,V,W, X,Y,Z, } \\
\text { a,b,c,d,e,f,g,h,l,j,k,l, m, n,o,p,q,r,s,t,u,v,w, }, \mathrm{x}, \mathrm{y}, \mathrm{z}])\end{array}$ & $\begin{array}{l}\text { CharAlpha } \\
\text { Num }\end{array}$ \\
\hline $\begin{array}{l}\text { Hexadecimal } \\
\text { Characters }\end{array}$ & Set-Str $([0,1,2,3,4,5,6,7,8,9, A, B, C, D, E, F])$ & CharHex \\
\hline $\begin{array}{l}\text { Unicode } \\
\text { Characters }\end{array}$ & $\begin{array}{l}\text { Set of all Unicode characters excluding the Special Reserved Characters } \\
\text { (CharReserved) defined in this table. (Represented as a Set-Str of single- } \\
\text { character strings). }\end{array}$ & CharU \\
\hline $\begin{array}{l}\text { Base64 } \\
\text { Characters }\end{array}$ & $\begin{array}{l}\text { Set-Str([0,1,2,3,4,5,6,7,8,9,A,B,C,D,E,F,G,H,I,J,K,L,M,N,O,P,Q,R,S,T,U,V,W, X,Y,Z, } \\
\text { a,b,c,d,e,f,g,h,I,j, , k,I,m,n,o,p,q,r,s,t,u,v,w,x,y,z,/,+,=]) }\end{array}$ & $\begin{array}{c}\text { CharBase6 } \\
4\end{array}$ \\
\hline $\begin{array}{l}\text { 7-bit ASCII } \\
\text { Characters }\end{array}$ & $\begin{array}{l}\text { All characters starting with Unicode }(U+0000) \text { and ending with Unicode(U+007F) } \\
\text { excluding the Special Reserved Characters defined in this table. (Represented as } \\
\text { a Set-Str of single-character strings). }\end{array}$ & CharAscii \\
\hline ASCII-Printable & All characters starting with Unicode(U+0020) and ending with Unicode(U+007E). & CharAsciiPr \\
\hline
\end{tabular}




\begin{tabular}{|c|c|c|}
\hline Characters & & intable \\
\hline $\begin{array}{l}\text { Special } \\
\text { Reserved } \\
\text { Characters }\end{array}$ & $\begin{array}{l}\text { Set-Str([Unicode(U+0002), Unicode(U+0003), Unicode(U+001C), } \\
\text { Unicode(U+001D), Unicode(U+001E), Unicode(U+001F)]) } \\
\text { (Special characters "STX", “ETX", “FS", “GS", “RS", and “US") }\end{array}$ & $\begin{array}{l}\text { CharReserv } \\
\quad \text { ed }\end{array}$ \\
\hline $\begin{array}{l}\text { Control } \\
\text { Characters }\end{array}$ & 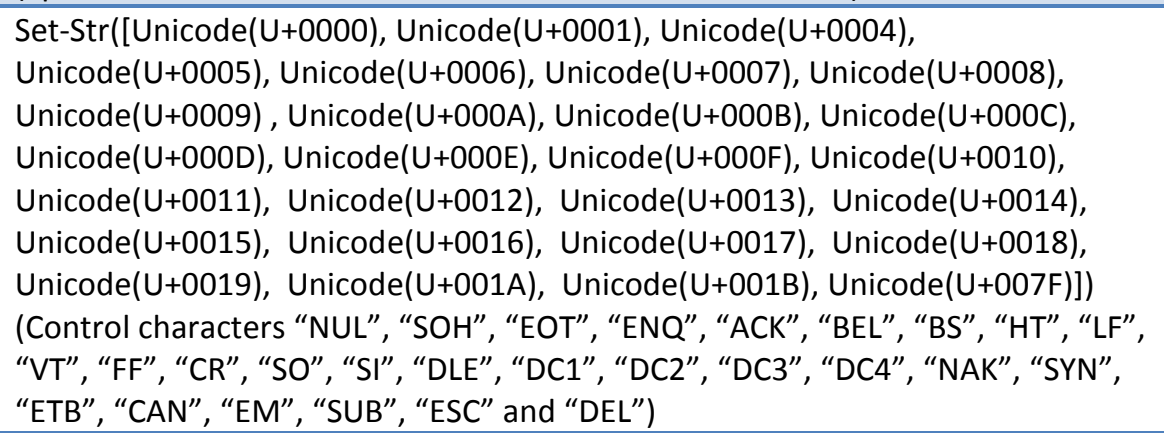 & CharCtrl \\
\hline $\begin{array}{l}\text { Resolution } \\
\text { Migration Path } \\
\text { (ppi) }\end{array}$ & $\begin{array}{l}\text { Set-Int([500,1000,2000,4000,8000, 16000, 32000, 64000]) (This represents } 500 \\
\text { ppi minimum with 100\% increase and a 5-digit maximum set by the field width } \\
\text { for THPS/TVPS) }\end{array}$ & $\begin{array}{l}\text { Resolution } \\
\text { Path-ppi }\end{array}$ \\
\hline $\begin{array}{l}\text { Resolution } \\
\text { Migration Path } \\
\text { (ppcm) }\end{array}$ & $\begin{array}{l}\text { Set-Int([197, 394, 787, 1575, 3150, 6299, 12598, 25197, 50394]) (This represents } \\
197 \text { ppcm minimum with } 100 \% \text { increase and a 5-digit maximum set by the field } \\
\text { width for THPS/TVPS) }\end{array}$ & $\begin{array}{l}\text { Resolution } \\
\text { Path-ppcm }\end{array}$ \\
\hline $\begin{array}{l}\text { ISO-3166-1 } \\
\text { Codes }\end{array}$ & Set-Str representing all values in the ISO Country Code Standard ISO-3166-1. & ISO-3166-1 \\
\hline $\begin{array}{l}\text { ISO-3166-1 } \\
\text { Alpha } 2 \text { Codes }\end{array}$ & $\begin{array}{l}\text { Set-Str of all 2-character alphabetic codes in the ISO Country Code Standard ISO- } \\
3166-1 .\end{array}$ & $\begin{array}{l}\text { ISO-3166- } \\
\text { 1-Alpha2 }\end{array}$ \\
\hline $\begin{array}{l}\text { ISO-3166-1 } \\
\text { Alpha } 3 \text { Codes }\end{array}$ & $\begin{array}{l}\text { Set-Str of all 3-character alphabetic codes in the ISO Country Code Standard ISO- } \\
3166-1 .\end{array}$ & $\begin{array}{l}\text { ISO-3166- } \\
\text { 1-Alpha3 }\end{array}$ \\
\hline $\begin{array}{l}\text { ISO-3166-1 } \\
\text { Numeric Codes }\end{array}$ & Set-Str of all numeric codes in the ISO Country Code Standard ISO-3166-1. & $\begin{array}{l}\text { ISO-3166- } \\
\text { 1-Numeric }\end{array}$ \\
\hline GENC Codes & $\begin{array}{l}\text { Set-Str representing all values in the GENC Country Code Standard, Edition } 2.0 \\
\text { (NGA.STND.0033_2.0). }\end{array}$ & GENC \\
\hline $\begin{array}{l}\text { GENC Alpha } 2 \\
\text { Codes }\end{array}$ & $\begin{array}{l}\text { Set-Str of all 2-character alphabetic codes in the GENC Country Code Standard, } \\
\text { Edition } 2.0 \text { (NGA.STND.0033_2.0). }\end{array}$ & $\begin{array}{l}\text { GENC- } \\
\text { Alpha2 }\end{array}$ \\
\hline $\begin{array}{l}\text { GENC Alpha } 3 \\
\text { Codes }\end{array}$ & $\begin{array}{l}\text { Set-Str of all 3-character alphabetic codes in the GENC Country Code Standard, } \\
\text { Edition 2.0 (NGA.STND.0033_2.0). }\end{array}$ & $\begin{array}{l}\text { GENC- } \\
\text { Alpha3 }\end{array}$ \\
\hline $\begin{array}{l}\text { GENC Numeric } \\
\text { Codes }\end{array}$ & $\begin{array}{l}\text { Set-Str of all numeric codes in the GENC Country Code Standard, Edition } 2.0 \\
\text { (NGA.STND.0033_2.0). }\end{array}$ & $\begin{array}{l}\text { GENC- } \\
\text { Numeric }\end{array}$ \\
\hline
\end{tabular}

The following String values represent image metadata tags that are defined for use in the syntax. Their positions within an image are based upon the compression algorithm of the image, indicated by the Image Type(s) column. Table 5.3 indicates tags that contain data, while Table 5.4 indicates tags that are used as positioning or identification markers in the image. For both tables, the Image Types may also be represented by the associated numeric code from Table 15 in AN-2013. Note: for PNG values in this table, values are converted from ppm to ppi or ppcm as indicated. This syntax follows the recommendation for rounding indicated in 7.7.8.5 of AN-2013 (round up).

Table 5.3 - Assertion Syntax: Value-based Image Metadata Tags 


\begin{tabular}{|c|c|c|}
\hline & & Image Metadata \\
\hline Term & $\begin{array}{l}\text { Image } \\
\text { Type(s) }\end{array}$ & Implementation \\
\hline \multirow{4}{*}{ Width } & JPEG & $4^{\text {th }}$ parameter of the Frame Header not counting the SOF marker \\
\hline & JP2 & $2^{\text {nd }}$ parameter of Image Header box \\
\hline & PNG & $1^{\text {st }}$ parameter of IHDR chunk \\
\hline & WSQ & $5^{\text {th }}$ parameter of SOF not counting the SOF marker \\
\hline \multirow{4}{*}{ Height } & JPEG & $3^{\text {rd }}$ parameter of the Frame Header not counting the SOF marker \\
\hline & JP2 & $1^{\text {st }}$ parameter of Image Header box \\
\hline & PNG & $2^{\text {nd }}$ parameter of IHDR chunk \\
\hline & WSQ & $4^{\text {th }}$ parameter of SOF not counting the SOF marker \\
\hline \multirow{4}{*}{ SamplingUnits } & JPEG & $4^{\text {th }}$ parameter in JFIF Header not counting the APPO Marker \\
\hline & JP2 & Undefined \\
\hline & PNG & $3^{\text {rd }}$ parameter of PHYS chunk (optional) \\
\hline & WSQ & Undefined \\
\hline \multirow{4}{*}{ HorzDensity-ppi } & JPEG & $5^{\text {th }}$ parameter in JFIF Header not counting the APPO Marker \\
\hline & JP2 & Undefined \\
\hline & PNG & 0.0254 (meters/inch) x $1^{\text {st }}$ parameter in PHYS Chunk (optional) \\
\hline & WSQ & Undefined \\
\hline \multirow{4}{*}{ HorzDensity-ppcm } & JPEG & $5^{\text {th }}$ parameter in JFIF Header not counting the APPO Marker \\
\hline & $\mathrm{JP2}$ & Undefined \\
\hline & PNG & 0.01 (meters $/ \mathrm{cm}$ ) $\times 1^{\text {st }}$ parameter in PHYS Chunk (optional) \\
\hline & WSQ & Undefined \\
\hline \multirow[t]{4}{*}{ VertDensity-ppi } & JPEG & $6^{\text {th }}$ parameter in JFIF Header not counting the APPO Marker \\
\hline & JP2 & Undefined \\
\hline & PNG & 0.0254 (meters/inch) $\times 2^{\text {nd }}$ parameter in PHYS Chunk (optional) \\
\hline & WSQ & Undefined \\
\hline \multirow{4}{*}{ VertDensity-ppcm } & JPEG & $6^{\text {th }}$ parameter in JFIF Header not counting the APPO Marker \\
\hline & JP2 & Undefined \\
\hline & PNG & 0.01 (meters $/ \mathrm{cm}) \times 2^{\text {nd }}$ parameter in PHYS Chunk (optional) \\
\hline & WSQ & Undefined \\
\hline \multirow{4}{*}{ AspectRatio } & JPEG & $\begin{array}{l}5^{\text {th }} \text { parameter in JFIF Header } / 6^{\text {th }} \text { parameter in JFIF Header (not } \\
\text { counting the APPO Marker) }\end{array}$ \\
\hline & JP2 & Undefined \\
\hline & PNG & $\begin{array}{l}1^{\text {st }} \text { parameter in PHYS Chunk } / 2^{\text {nd }} \text { parameter in PHYS Chunk } \\
\text { (optional) }\end{array}$ \\
\hline & WSQ & Undefined \\
\hline \multirow[t]{4}{*}{ BPX } & JPEG & 2nd parameter of the Frame Header not counting the SOF marker \\
\hline & JP2 & $\begin{array}{l}7 \mathrm{LSB} \text { of } 4^{\text {th }} \text { parameter of ImgBox }+1 \text { if } 4^{\text {th }} \text { parameter of ImgBox is not } \\
255\end{array}$ \\
\hline & PNG & $3^{\text {rd }}$ parameter of IHDR chunk \\
\hline & WSQ & Undefined \\
\hline \multirow{4}{*}{ CSP } & JPEG & Undefined \\
\hline & JP2 & $4^{\text {th }}$ parameter of Colour Specification box \\
\hline & PNG & $4^{\text {th }}$ parameter of IHDR chunk \\
\hline & WSQ & Undefined \\
\hline
\end{tabular}


Table 5.4 - Assertion Syntax: Marker-based Image Metadata Tags

\begin{tabular}{|c|c|c|}
\hline \multicolumn{3}{|r|}{ Image Metadata } \\
\hline Image Type & $\begin{array}{l}\text { Valid Image } \\
\text { Markers }\end{array}$ & Implementation \\
\hline \multirow[t]{4}{*}{ JPEG } & SOI & Start of JPEG type image. \\
\hline & SOF & Start of frame in a JPEG type image. \\
\hline & EOI & End of a JPEG image. \\
\hline & JFIF Header & $\begin{array}{l}\text { Frame for specifying JPEG type image metadata. Its inclusion is } \\
\text { required by the standard. }\end{array}$ \\
\hline \multirow[t]{4}{*}{ JP2 } & SigBox & Signature Box that marks the start of a JP2 type image. \\
\hline & HeadBox & Header Box in a JP2 type image. \\
\hline & ImgBox & Image Header Box in a JP2 type image. \\
\hline & EOI & End of JP2 image. \\
\hline \multirow[t]{4}{*}{ PNG } & PNGSig & Signature of a PNG image. \\
\hline & IHDR & Image Header Chunk in a PNG image. \\
\hline & IDAT & Image Data Chunk in a PNG image. \\
\hline & IEND & Image End Chunk in a PNG image. \\
\hline \multirow[t]{3}{*}{ WSQ } & SOI & Start of WSQ type image. \\
\hline & SOF & Start of frame in a WSQ type image. \\
\hline & EOI & End of a WSQ image. \\
\hline
\end{tabular}

\section{Expressions}

Test Assertions are composed of one or more Expressions, which are statements that return a Value Type as defined in the Value-Type Definitions table. Each Expression has a single Operator, a set of valid Operands, and Return Type. Expressions may serve as Operands of other Expressions as long as their Return Type is a valid Operand for that Expression.

The tables below include a complete description of the Expressions and their required Operators and Operands used throughout the requirements and assertion tables. The Operators are categorized according to the type of Expression in which they are used and the Return Type they produce. Return Types must be a valid Value Type. The tables indicate the following information for each Expression:

- Expression Name: the name of the Expression

- Description: an explanation of how the Expression is used to return the specified Value Type

- Return Type: the Return Type that is returned from the Expression. The Return Type must be a valid Value Type.

- Operands Types: the number and type of operands accepted by the Expression. In addition to the Value Type indicated, any Expression that returns that type can be used as an Operand. Underlined Operands are optional. If operands are not formatted properly, the test assertion that contains the expression has a failing TestResult.

- Operator Syntax: the Operator used to represent the Expression in the assertion tables 


\section{Boolean Expressions-}

These Expressions return Boolean Values. There are several types of Boolean Expressions including Relational (comparison between values), Logical (Boolean logic statements), and Conditional (if/then) Boolean expressions.

\section{Result Expressions-}

These Expressions return a Test Result, meaning that the value may be Pass, Fail, or Warning. This is the only expression type capable of generating a Warning.

Numeric Expressions-

These Expressions return a Numeric value or any of its sub-types: NumericInteger or NumericByte.

String Expressions-

These Expressions return a String value.

Generic Expressions-

These Expressions return values that depend upon the Operand Type used with the expression. Each Generic Expression is intended to be used with various Value-Types.

Table 5.5 - Assertion Syntax: Expression Definitions

\begin{tabular}{|c|c|c|c|c|c|}
\hline \multicolumn{6}{|c|}{ Expression Definitions } \\
\hline & Expression Name & Description & Return Type & Operand Types & Operator Syntax \\
\hline \multirow{7}{*}{$\begin{array}{l}\frac{5}{0} \\
\frac{0}{0} \\
0 \\
\infty\end{array}$} & Equal To & $\begin{array}{l}\text { Relational Test for equality between } \\
\text { two operands Op1 and Op2. For } \\
\text { comparisons between String and } \\
\text { Numeric types, the String value is } \\
\text { converted to Numeric first (if it cannot } \\
\text { be converted, the result is FALSE). } \\
\text { Ex. EQ(Str(4.0), Num(4)) is TRUE } \\
\text { Ex. EQ(Str(4.0), Str(4)) is FALSE }\end{array}$ & Boolean & $\begin{array}{l}\text { Op1: Numeric or } \\
\text { String } \\
\text { Op2: Numeric or } \\
\text { String }\end{array}$ & $\mathrm{EQ}(\mathrm{Op} 1, \mathrm{Op} 2)$ \\
\hline & Not Equal To & $\begin{array}{l}\text { Relational Test for non-equality } \\
\text { between two operands Op1 and Op2. } \\
\text { For comparisons between String and } \\
\text { Numeric types, the String value is } \\
\text { converted to Numeric first (if it cannot } \\
\text { be converted, the result is TRUE). }\end{array}$ & Boolean & $\begin{array}{l}\text { Op1: Numeric or } \\
\text { String } \\
\text { Op2: Numeric or } \\
\text { String }\end{array}$ & NEQ(Op1, Op2) \\
\hline & Greater Than & $\begin{array}{l}\text { Relational Test for if Op1 is greater } \\
\text { than Op2. }\end{array}$ & Boolean & $\begin{array}{l}\text { Op1: Numeric } \\
\text { Op2: Numeric }\end{array}$ & GT(Op1, Op2) \\
\hline & $\begin{array}{l}\text { Greater Than or } \\
\text { Equal To }\end{array}$ & $\begin{array}{l}\text { Relational Test for if Op1 is greater } \\
\text { than or equal to Op2. }\end{array}$ & Boolean & $\begin{array}{l}\text { Op1: Numeric } \\
\text { Op2: Numeric }\end{array}$ & GTE(Op1, Op2) \\
\hline & Less Than & $\begin{array}{l}\text { Relational Test for if Op1 is less than } \\
\text { Op2. }\end{array}$ & Boolean & $\begin{array}{l}\text { Op1: Numeric } \\
\text { Op2: Numeric }\end{array}$ & LT(Op1, Op2) \\
\hline & Less Than or Equal To & $\begin{array}{l}\text { Relational Test for if Op1 is less than or } \\
\text { equal to Op2. }\end{array}$ & Boolean & $\begin{array}{l}\text { Op1: Numeric } \\
\text { Op2: Numeric }\end{array}$ & LTE(Op1, Op2) \\
\hline & Range (Inclusive) & $\begin{array}{l}\text { Relational Test for if Op1 is in the range } \\
\text { of values specified Op2 and Op3, where } \\
\text { Op2 is the minimum numeric value and } \\
\text { Op3 is the maximum numeric value. } \\
\text { Ex: InRange(Num(10.1), Num(10.0), } \\
\text { Num(10.3)) returns TRUE. }\end{array}$ & Boolean & $\begin{array}{l}\text { Op1: Numeric } \\
\text { Op2: Numeric } \\
\text { Op3: Numeric }\end{array}$ & $\begin{array}{l}\text { InRange(Op1, Op2, } \\
\text { Op3) }\end{array}$ \\
\hline
\end{tabular}




\begin{tabular}{|c|c|c|c|c|}
\hline \multicolumn{5}{|c|}{ Expression Definitions } \\
\hline Expression Name & Description & Return Type & Operand Types & Operator Syntax \\
\hline Member Of & $\begin{array}{l}\text { Relational Test for if the value Op1 is a } \\
\text { contained within the set Op2. }\end{array}$ & Boolean & $\begin{array}{l}\text { Op1: Numeric or } \\
\text { String } \\
\text { Op2: Set-Numeric or } \\
\text { Set or Set-String } \\
\text { Op2 Set Type must } \\
\text { match Op1 Value } \\
\text { Type. }\end{array}$ & $\mathrm{MO}(\mathrm{Op} 1, \mathrm{Op} 2)$ \\
\hline Any Member Of & $\begin{array}{l}\text { Relational Test for if any values in the } \\
\text { Set Op1 are a member of the Set Op2. }\end{array}$ & Boolean & $\begin{array}{l}\text { Op1: Set (any type) } \\
\text { Op2: Set (any type) } \\
\text { The Set type of Op1 } \\
\text { and Op2 must be the } \\
\text { same. }\end{array}$ & AnyMO(Op1, Op2) \\
\hline Is Subset Of & $\begin{array}{l}\text { Relational Test for if the Set Op1 is a } \\
\text { subset of the Set Op2, represented } \\
\text { mathematically as Op1 } \subseteq \text { Op2. This } \\
\text { means that every value in Set Op1 must } \\
\text { exist in Set Op2. If a value repeats in } \\
\text { set Op1, only one instance is required } \\
\text { in Set Op2. Note that this does not } \\
\text { have to be a proper subset. One use of } \\
\text { this Expression is to test for character } \\
\text { types, for example: } \\
\text { SubSet(Chars(\{Fld(1.002)\}), CharNum) }\end{array}$ & Boolean & $\begin{array}{l}\text { Op1: Set (any type) } \\
\text { Op2: Set (any type) } \\
\text { The Set type of Op1 } \\
\text { and Op2 must be the } \\
\text { same. }\end{array}$ & SubSet(Op1, Op2) \\
\hline Logical And & $\begin{array}{l}\text { Logical Test returns the result of the } \\
\text { logical AND of two Boolean operands, } \\
\text { Op1 and Op2. Returns TRUE only if } \\
\text { both Op1 and Op2 are TRUE. }\end{array}$ & Boolean & $\begin{array}{l}\text { Op1: Boolean } \\
\text { Op2: Boolean }\end{array}$ & AND(Op1, Op2) \\
\hline Logical Or & $\begin{array}{l}\text { Logical Test returns the result of the } \\
\text { logical OR of two Boolean operands, } \\
\text { Op1 and Op2. Returns TRUE if either } \\
\text { Op1 or Op2 is TRUE. }\end{array}$ & Boolean & $\begin{array}{l}\text { Op1: Boolean } \\
\text { Op2: Boolean }\end{array}$ & OR(Op1, Op2) \\
\hline Logical Exclusive Or & $\begin{array}{l}\text { Logical Test returns the result of the } \\
\text { logical XOR of two Boolean operands, } \\
\text { Op1 and Op2. Returns TRUE if only one } \\
\text { of the operands is TRUE and the other } \\
\text { operand is FALSE. }\end{array}$ & Boolean & $\begin{array}{l}\text { Op1: Boolean } \\
\text { Op2: Boolean }\end{array}$ & XOR(Op1, Op2) \\
\hline Logical Negate & $\begin{array}{l}\text { Logical Test returns a value that is the } \\
\text { logical opposite of the operand, Op1. } \\
\text { Returns TRUE only if Op1 is FALSE. }\end{array}$ & Boolean & Op1: Boolean & NOT(Op1) \\
\hline Conditional If/Then & $\begin{array}{l}\text { Conditional Test evaluates the } \\
\text { conditional statement of IF Op1, THEN } \\
\text { Op2, where Op1 and Op2 are of } \\
\text { Boolean Value-Type. The expression } \\
\text { returns Op2 if Op1 is TRUE and TRUE } \\
\text { otherwise. }\end{array}$ & Boolean & $\begin{array}{l}\text { Op1: Boolean } \\
\text { Op2: Boolean }\end{array}$ & IfThen(Op1, Op2) \\
\hline $\begin{array}{l}\text { Conditional } \\
\text { If/Then/Else }\end{array}$ & $\begin{array}{l}\text { Conditinal Test evaluates the } \\
\text { conditional statement of IF Op1, THEN } \\
\text { Op2, ELSE Op3, where Op1, Op2, and } \\
\text { Op3 are of Boolean Value-Type. The }\end{array}$ & Boolean & $\begin{array}{l}\text { Op1: Boolean } \\
\text { Op2: Boolean } \\
\text { Op3: Boolean }\end{array}$ & $\begin{array}{l}\text { IfThenElse(Op1, Op2, } \\
\text { Op3) }\end{array}$ \\
\hline
\end{tabular}




\begin{tabular}{|c|c|c|c|c|}
\hline \multicolumn{5}{|c|}{ Expression Definitions } \\
\hline Expression Name & Description & Return Type & Operand Types & Operator Syntax \\
\hline & $\begin{array}{l}\text { expression returns Op2 if Op1 is TRUE } \\
\text { and Op3 otherwise. }\end{array}$ & & & \\
\hline $\begin{array}{l}\text { Conditional If and } \\
\text { Only If }\end{array}$ & $\begin{array}{l}\text { Conditional Test evaluates the } \\
\text { conditional statement of Op1 IF AND } \\
\text { ONLY IF Op2. The expression is } \\
\text { equivalent to IF Op1, THEN Op2 AND IF } \\
\text { Op2, THEN Op1. }\end{array}$ & Boolean & $\begin{array}{l}\text { Op1: Boolean } \\
\text { Op2: Boolean }\end{array}$ & Iff(Op1, Op2) \\
\hline Entity Present & $\begin{array}{l}\text { General Boolean Test returns a result } \\
\text { indicating whether the entity or set of } \\
\text { entities represented by the operand } \\
\text { Op1 is present. AnyPresent indicates if } \\
\text { any of the entities in the set Op2 are } \\
\text { present. AllPresent indicates if all of the } \\
\text { entities are present. Note: presence of } \\
\text { Information Items is indicated by both } \\
\text { the information separator tag and data } \\
\text { being present. } \\
\text { Ex: } \\
\text { Present(Fld(1.001)) checks if Field } \\
1.001 \text { is present. } \\
\text { Present(Set-Rec([10 to } 15])) \text { checks if } \\
\text { Record Types } 10 \text { to } 15 \text { are present. }\end{array}$ & Boolean & $\begin{array}{l}\text { Op1: Entity or Set- } \\
\text { Entity } \\
\text { Op2: Set-Entity }\end{array}$ & $\begin{array}{l}\text { Present(Op1) } \\
\text { Or } \\
\text { AnyPresent(Op2) } \\
\text { Or } \\
\text { AllPresent(Op2) }\end{array}$ \\
\hline $\begin{array}{l}\text { Information Item } \\
\text { Structure }\end{array}$ & $\begin{array}{l}\text { General Boolean Test that returns a } \\
\text { result indicating whether or not the } \\
\text { Information Items indicated by the 1- } \\
\text { based indexes in Op2 are present (with } \\
\text { data) in the Field or Subfield } \\
\text { represented by Op1. If Op2 is not } \\
\text { specified, then all Information Items } \\
\text { must have data. Note that Op1 is } \\
\text { permitted to be more than one } \\
\text { subfield, for example: } \\
\text { InfoltemsHaveData(SubFld(1.003), Set- } \\
\text { Int([1,2])) indicates that the first and } \\
\text { second information item in every } \\
\text { subfield of Field } 1.003 \text { must have data. }\end{array}$ & Boolean & $\begin{array}{l}\text { Op1: EntityField or } \\
\text { EntitySubField } \\
\text { Op2: Set-Integer }\end{array}$ & \\
\hline $\begin{array}{l}\text { Image Tags Match } \\
\text { Compression } \\
\text { Algorithm }\end{array}$ & $\begin{array}{l}\text { A General Boolean Test that returns a } \\
\text { result indicating whether the Image in } \\
\text { the field Op2 contains the valid } \\
\text { metadata tags (indicated in Table 5.4) } \\
\text { for the compression type specified in } \\
\text { the field Op1. For uncompressed } \\
\text { images, this test always returns TRUE. }\end{array}$ & Boolean & $\begin{array}{l}\text { Op1: EntityField or } \\
\text { EntityElement } \\
\text { Op2: EntityField or } \\
\text { EntityElement }\end{array}$ & \\
\hline Image Tags Valid & $\begin{array}{l}\text { A General Boolean Test that returns a } \\
\text { result indicating whether the Image in } \\
\text { field Op1 contains valid image } \\
\text { metadata tags for any of the Image } \\
\text { Types specified in Table } 5.4 \text {. For } \\
\text { uncompressed images, this test always }\end{array}$ & Boolean & $\begin{array}{l}\text { Op1: EntityField or } \\
\text { EntityElement }\end{array}$ & \\
\hline
\end{tabular}




\begin{tabular}{|c|c|c|c|c|c|}
\hline \multicolumn{6}{|c|}{ Expression Definitions } \\
\hline & Expression Name & Description & Return Type & Operand Types & Operator Syntax \\
\hline & & returns TRUE. & & & \\
\hline & $\begin{array}{l}\text { Image Tag Value } \\
\text { Compare }\end{array}$ & $\begin{array}{l}\text { A General Boolean Test that returns a } \\
\text { result indicating whether the Image Tag } \\
\text { Op2 in the Image in field Op3 matches } \\
\text { the value in field Op1. For } \\
\text { uncompressed images, this test always } \\
\text { returns TRUE (with a message } \\
\text { indicating that these tests are not } \\
\text { performed on uncompressed images). } \\
\text { Op2 is a Term value from Table 5.3. }\end{array}$ & Boolean & $\begin{array}{l}\text { Op1: EntityField or } \\
\text { EntityElement } \\
\text { Op2: String } \\
\text { Op3: EntityField or } \\
\text { EntityElement }\end{array}$ & \\
\hline & $\begin{array}{l}\text { Image Tag Value } \\
\text { Compare Aspect } \\
\text { Ratio }\end{array}$ & $\begin{array}{l}\text { A General Boolean Test that returns a } \\
\text { result indicating whether the Aspect } \\
\text { Ratio (Table 5.3) in the Image in field } \\
\text { Op3 matches the ratio of the values in } \\
\text { Op1 to Op2. For uncompressed images, } \\
\text { this test always returns TRUE (with a } \\
\text { message indicating that these tests are } \\
\text { not performed on uncompressed } \\
\text { images). For divide by zero, this test } \\
\text { returns FALSE. }\end{array}$ & Boolean & $\begin{array}{l}\text { Op1: EntityField or } \\
\text { EntityElement } \\
\text { Op2: EntityField or } \\
\text { EntityElement } \\
\text { Op3: EntityField or } \\
\text { EntityElement }\end{array}$ & \\
\hline \multirow{3}{*}{$\frac{ \pm}{\bar{y}}$} & If/Then Result & $\begin{array}{l}\text { Conditional Test evaluates the } \\
\text { conditional statement of IF Op1, THEN } \\
\text { Op2. The expression returns Op2 if Op1 } \\
\text { is TRUE and PASS otherwise. }\end{array}$ & Test Result & $\begin{array}{l}\text { Op1: Boolean } \\
\text { Op2: TestResult }\end{array}$ & IfThenResult(Op1, Op2) \\
\hline & If/Then/Else Result & $\begin{array}{l}\text { Conditional Test evaluates the } \\
\text { conditional statement of IF Op1, THEN } \\
\text { Op2, ELSE Op3. The expression returns } \\
\text { Op2 if Op1 is TRUE and Op3 otherwise. } \\
\text { If Op2 or Op3 is of type Boolean, the } \\
\text { Expression returns PASS for TRUE and } \\
\text { FAIL for FALSE values. }\end{array}$ & Test Result & $\begin{array}{l}\text { Op1: Boolean } \\
\text { Op2: TestResult or } \\
\text { Boolean } \\
\text { Op3: TestResult or } \\
\text { Boolean } \\
\text { At least one of Op2 } \\
\text { and Op3 must be a } \\
\text { Test Result }\end{array}$ & $\begin{array}{l}\text { IfThenElseResult(Op1, } \\
\text { Op2, Op3) }\end{array}$ \\
\hline & Generate Test Result & $\begin{array}{l}\text { Returns a TestResult that is provided as } \\
\text { the operand Op1. If Op } 1 \text { is Boolean, } \\
\text { then True is converted to Pass and } \\
\text { False is Converted to Fail. }\end{array}$ & Test Result & $\begin{array}{l}\text { Op1: Boolean or } \\
\text { TestResult }\end{array}$ & ReturnResult(Op1) \\
\hline \multirow[t]{2}{*}{ 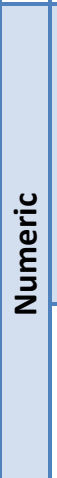 } & Numeric Value & $\begin{array}{l}\text { Returns the Numeric Value } \\
\text { represented by the operand Op1. If } \\
\text { Op1 is a String, it must be a properly } \\
\text { formatted number with no leading } \\
\text { zeros. If Op1 is a Byte Set, the entire } \\
\text { set of bytes is interpreted as a value. } \\
\text { Ex: NV(Set-Byte([0x01, 0x00])) is } 256\end{array}$ & Numeric & $\begin{array}{l}\text { Op1: String or Byte } \\
\text { Set }\end{array}$ & $N V(O p 1)$ \\
\hline & Count & $\begin{array}{l}\text { Returns the number of values found in } \\
\text { the Set operand Op1. } \\
\text { This is frequently used with Entity Sets } \\
\text { to find the occurrence of an entity, for }\end{array}$ & $\begin{array}{l}\text { Numericlntege } \\
r\end{array}$ & Op1: Set (Any Type) & Count(Op1) \\
\hline
\end{tabular}









\begin{tabular}{|c|c|c|c|c|c|}
\hline \multicolumn{6}{|c|}{ Expression Definitions } \\
\hline & Expression Name & Description & Return Type & Operand Types & Operator Syntax \\
\hline \multirow{5}{*}{ 胥 } & String Value & $\begin{array}{l}\text { Returns the String Value generated by } \\
\text { decoding the binary data of the Entity } \\
\text { Operand Op1 according to the } \\
\text { specified character encoding for that } \\
\text { Entity. For EntityElements, leading and } \\
\text { trailing whitespace is ignored. Use } \\
\text { WS\{Op1\} to force leading and trailing } \\
\text { whitespace to be included for } \\
\text { EntityElements. This is important } \\
\text { because XML Elements frequently } \\
\text { contain leading and trailing whitespace } \\
\text { e that is not part of the data, but rather } \\
\text { for formatting. }\end{array}$ & String & $\begin{array}{l}\text { Op1: EntityField, } \\
\text { EntityInfoltem, or } \\
\text { EntityElement }\end{array}$ & $\{0 p 1\}$ \\
\hline & $\begin{array}{l}\text { String Value (With } \\
\text { Leading and Trailing } \\
\text { Whitespace) }\end{array}$ & $\begin{array}{l}\text { Returns the String Value (including } \\
\text { leading and trailing whitespace) } \\
\text { generated by decoding the binary data } \\
\text { of the EntityElement Operand Op } 1 \\
\text { according to the specified character } \\
\text { encoding for that Entity. }\end{array}$ & String & Op1: EntityElement & WS $\{0 p 1\}$ \\
\hline & Element Name & $\begin{array}{l}\text { Returns the String Value that } \\
\text { represents the XML Element name. }\end{array}$ & String & $\begin{array}{l}\text { Op1: EntityElement or } \\
\text { EntityContainerEleme } \\
\text { nt }\end{array}$ & ElmName(Op1) \\
\hline & String from ASCII & $\begin{array}{l}\text { Returns the String Value of the ASCII } \\
\text { code operand Op1. If any value in the } \\
\text { operand is outside the range of 7-bit } \\
\text { ASCII values, this expression returns an } \\
\text { empty String. For Set-Numeric } \\
\text { operands, each number in the set } \\
\text { represents one ASCII character. Ex. } \\
\text { ASCII(Set-Num([0x30, } 0 \times 31])) \text { is } 01 \text { and } \\
\text { ASCII(Num(33)) is! }\end{array}$ & String & $\begin{array}{l}\text { Op1: Numeric or Set- } \\
\text { Numeric }\end{array}$ & ASCII(Op1) \\
\hline & String from Unicode & $\begin{array}{l}\text { Returns the String Value of the Unicode } \\
\text { Codepoint operand Op1. If any } \\
\text { codepoint in the operand is invalid, it } \\
\text { returns an empty String. For String sets, } \\
\text { each string represents one Unicode } \\
\text { codepoint (and thus one character) Ex. } \\
\text { Unicode(Set-Str([U+0030, U+0033])) is } \\
03\end{array}$ & String & $\begin{array}{l}\text { Op1: String or String } \\
\text { Set }\end{array}$ & Unicode(Op1) \\
\hline 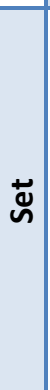 & Byte Values & $\begin{array}{l}\text { Returns a Set of Byte Values } \\
\text { representing the exact binary data } \\
\text { contained in the Entity Operand Op1 in } \\
\text { Big-Endian format. Note: this includes } \\
\text { any separator characters. } \\
\text { If Op1 is an EntityField, the field } \\
\text { number FN (e.g. "1.001:") is not part of } \\
\text { the byte data. However, if Op1 is an } \\
\text { EntityRecord, all data in the record, }\end{array}$ & $\begin{array}{l}\text { Set- } \\
\text { NumericByte }\end{array}$ & $\begin{array}{l}\text { Op1: EntityField, } \\
\text { EntityInfoltem, } \\
\text { EntitySubField, } \\
\text { EntityRecord }\end{array}$ & Bytes(Op1) \\
\hline
\end{tabular}




\begin{tabular}{|c|c|c|c|c|}
\hline \multicolumn{5}{|c|}{ Expression Definitions } \\
\hline Expression Name & Description & Return Type & Operand Types & Operator Syntax \\
\hline & $\begin{array}{l}\text { including field numbers, is part of the } \\
\text { data. }\end{array}$ & & & \\
\hline Character Values & $\begin{array}{l}\text { Returns a Set of String Values, with } \\
\text { each string representing one character } \\
\text { in the operand Op1. } \\
\text { Ex: Chars(Str(value)) is Set- } \\
\text { Str([v,a,l,u,e]) }\end{array}$ & Set-String & Op1: String & Chars(Op1) \\
\hline List Values & $\begin{array}{l}\text { Returns the Set of String Values found } \\
\text { in the StringList Op1. } \\
\text { Ex: ListValues(StrList }(A|B| C)) \text { is Set- } \\
\text { Str }([A, B, C])\end{array}$ & Set-String & Op1: StringList & ListValues(Op1) \\
\hline String Values & $\begin{array}{l}\text { Returns the set of String Values } \\
\text { generated by decoding the binary data } \\
\text { of each of the Entities in the Entity-Set } \\
\text { Operand Op1 according to the } \\
\text { specified character encoding for that } \\
\text { Entity. For EntityElements, leading and } \\
\text { trailing whitespace is ignored. Use } \\
\text { WS\{Op1\} to force leading and trailing } \\
\text { whitespace to be included for } \\
\text { EntityElements. This is important } \\
\text { because XML Elements frequently } \\
\text { contain leading and trailing whitespace } \\
\text { e that is not part of the data, but rather } \\
\text { for formatting. }\end{array}$ & Set-String & Op1: Set-Entity & Set-\{Op1\} \\
\hline Numeric Values & $\begin{array}{l}\text { Returns the set of Numeric Values } \\
\text { represented by the set of Strings in } \\
\text { Op1, which must be properly formatted } \\
\text { numbers with no leading zeros. }\end{array}$ & Set-Numeric & Op1: Set-String & Set-NV(Op1) \\
\hline Binary from Base64 & $\begin{array}{l}\text { Returns a set of bytes that represents } \\
\text { the decoded Base- } 64 \text { value found in } \\
\text { Op1. If Op1 is not a valid Base- } 64 \\
\text { encoded string, this expression returns } \\
\text { an empty set. }\end{array}$ & $\begin{array}{l}\text { Set- } \\
\text { NumericByte }\end{array}$ & $\begin{array}{l}\text { Op1: String } \\
\text { Op1 must be a valid } \\
\text { Base- } 64 \text { string }\end{array}$ & B64toBytes(Op1) \\
\hline Record Set & $\begin{array}{l}\text { Returns the Set of Records present in } \\
\text { the transaction. If Op1 is specified, it } \\
\text { represents the record type desired. An } \\
\text { Integer value represents the Record } \\
\text { Type. A Set-Numericlnteger represents } \\
\text { any number of Record Types, and a } \\
\text { string represents the XML Element } \\
\text { name of the record types desired. For } \\
\text { example: Recs(Int(10)) returns the Set } \\
\text { of Type-10 Records present in the } \\
\text { transaction. Recs(Set-Int([13,14])) is the } \\
\text { Set of Type-13 and Type-14 Records. }\end{array}$ & $\begin{array}{l}\text { Set- } \\
\text { EntityRecord }\end{array}$ & $\begin{array}{l}\text { Op1: Numericlnteger, } \\
\text { Set-Numericlnteger, } \\
\text { or String }\end{array}$ & $\operatorname{Recs}(\underline{0 p 1})$ \\
\hline
\end{tabular}




\begin{tabular}{|c|c|c|c|c|}
\hline \multicolumn{5}{|c|}{ Expression Definitions } \\
\hline Expression Name & Description & Return Type & Operand Types & Operator Syntax \\
\hline & $\begin{array}{l}\text { Recs represents all records in the } \\
\text { transaction. }\end{array}$ & & & \\
\hline $\begin{array}{l}\text { Field Set In } \\
\text { Transaction }\end{array}$ & $\begin{array}{l}\text { Returns the Set of Fields in the } \\
\text { Transaction with the specified Field } \\
\text { Number, that match the EntityField, or } \\
\text { that exist in the EntityRecord indicated } \\
\text { by operand Op1. For example: } \\
\text { FldsInTx(Int(999)) is the Set of Fields } \\
999 \text { in any Record Type in the } \\
\text { Transaction. FldsInTx(Fld(13.002)) is the } \\
\text { set of Field } 002 \text { in any Type-13 Record. } \\
\text { FldsInTx(Rec(10)) is the set of Fields in } \\
\text { every Record Type-10. FldsInTx is the } \\
\text { Set of all Fields in the Transaction. } \\
\text { Note: This is the set of Fields among } \\
\text { separate Records in the Transaction. } \\
\text { For Fields in a single Record instance } \\
\text { use FIdsInRec. }\end{array}$ & Set-EntityField & $\begin{array}{l}\text { Op1: Numericlnteger, } \\
\text { EntityField, or } \\
\text { EntityRecord }\end{array}$ & FldsInTx(ㅁ1) \\
\hline Field Set In Record & $\begin{array}{l}\text { Returns the Set of Fields in a given } \\
\text { Record operand Op1. If Op2 is specified } \\
\text { it is the Field Number desired. For } \\
\text { example: FldsInRec(Rec(1)) is the Set of } \\
\text { Fields in } \operatorname{Record} \operatorname{Type-1.} \\
\text { FldsInRec(Rec(10),Int }(1)) \text { is the set of } \\
\text { Fields } 001 \text { in a single Record Type-10. } \\
\text { Note: This is the set of Fields in one } \\
\text { instance of a record. For Fields among } \\
\text { several separate Records, use FldsInTx. }\end{array}$ & Set-EntityField & $\begin{array}{l}\text { Op1: EntityRecord } \\
\text { Op2: Numericlnteger }\end{array}$ & FldsInRec(Op1, Op2) \\
\hline Subfield Set & $\begin{array}{l}\text { Returns the Set of SubFields found in } \\
\text { the Field operand Op1. }\end{array}$ & $\begin{array}{l}\text { Set- } \\
\text { EntitySubfield }\end{array}$ & Op1: EntityField & SubFIdsIn(Op1) \\
\hline $\begin{array}{l}\text { Information Item Set } \\
\text { In Transaction }\end{array}$ & $\begin{array}{l}\text { Returns the Set of Information Items in } \\
\text { the Transaction. If Op1 is specified, it } \\
\text { represents the Information Item } \\
\text { mnemonic desired. For example: } \\
\text { InfoltemsInTx(Str(IDC)) is the Set of } \\
\text { Information Items with mnemonic } \\
\text { "IDC". InfoltemsInTx is the Set of all } \\
\text { information items in the transaction. } \\
\text { This expression identifies information } \\
\text { items using their information separator } \\
\text { tags, so even empty information items } \\
\text { are returned by this expression. } \\
\text { Note: This is the set of Information } \\
\text { Items among separate Records in the } \\
\text { Transaction. For Information Items in }\end{array}$ & $\begin{array}{l}\text { Set- } \\
\text { Entitylnfoltem }\end{array}$ & $\begin{array}{l}\text { Op1: EntityField or } \\
\text { EntitySubField }\end{array}$ & InfoltemsInTx(ㅁ1) \\
\hline
\end{tabular}




\begin{tabular}{|c|c|c|c|c|c|}
\hline \multicolumn{6}{|c|}{ Expression Definitions } \\
\hline & Expression Name & Description & Return Type & Operand Types & Operator Syntax \\
\hline & & $\begin{array}{l}\text { a single Record instance use } \\
\text { Infoltemsin. }\end{array}$ & & & \\
\hline & $\begin{array}{l}\text { Information Item Set } \\
\text { In Record }\end{array}$ & $\begin{array}{l}\text { Returns the Set of Information Items } \\
\text { found in the Field or Subfield operand } \\
\text { Op1. If Op2 is specified, it represents } \\
\text { the Information Item mnemonic } \\
\text { desired. For example: } \\
\text { InfoltemsIn(Fld(1.003), Str(IDC)) is the } \\
\text { Set of Information Items with } \\
\text { mnemonic "IDC" in field 1.003. This } \\
\text { expression identifies information items } \\
\text { using their information separator tags, } \\
\text { so even empty information items are } \\
\text { returned by this expression. Note: This } \\
\text { is the set of Information Items in one } \\
\text { instance of a record. For Information } \\
\text { Items among several separate } \\
\text { Records, use InfoltemsInTx. }\end{array}$ & $\begin{array}{l}\text { Set- } \\
\text { EntityInfoltem }\end{array}$ & $\begin{array}{l}\text { Op1: EntityField or } \\
\text { EntitySubField } \\
\text { Op2: String }\end{array}$ & InfoltemsIn(Op1, Op2) \\
\hline & $\begin{array}{l}\text { Element Set in } \\
\text { Transaction }\end{array}$ & $\begin{array}{l}\text { Returns the Set of XML elements in } \\
\text { every Op1 in the transaction. If Op2 is } \\
\text { used, it provides the name of the } \\
\text { desired elements. If ChEImsInTx is } \\
\text { used, only direct child elements are } \\
\text { considered. ElmsInTx with no operands } \\
\text { returns the set of all elements in the } \\
\text { transaction. Note: This is the set of } \\
\text { elements among all Op1 instances in } \\
\text { the Transaction. For elements in a } \\
\text { single Op1 instance use ElmsIn. }\end{array}$ & $\begin{array}{l}\text { Set- } \\
\text { EntityElement } \\
\text { or } \\
\text { SetEntityConta } \\
\text { inerElement }\end{array}$ & $\begin{array}{l}\text { Op1: EntityElement or } \\
\text { EntityContainerEleme } \\
\text { nt } \\
\text { Op2: EntityElement or } \\
\text { EntityContainerEleme } \\
\text { nt }\end{array}$ & $\begin{array}{l}\text { ElmsInTx(ㅁ1, Op2 }) \\
\text { Or } \\
\text { ChElmsInTx(p1, Op2 })\end{array}$ \\
\hline & Element Set & $\begin{array}{l}\text { Returns the Set of XML elements in a } \\
\text { specific Op1. If Op2 is used, it provides } \\
\text { the name of the desired elements. If } \\
\text { ChElmsIn is used, only direct child } \\
\text { elements are considered. Note: This is } \\
\text { the set of elements in one instance of } \\
\text { an Op1. For elements among several } \\
\text { instances of Op1, use ElmsInTx. }\end{array}$ & $\begin{array}{l}\text { Set- } \\
\text { EntityElement } \\
\text { or } \\
\text { SetEntityConta } \\
\text { inerElement }\end{array}$ & $\begin{array}{l}\text { Op1: EntityElement or } \\
\text { EntityContainerEleme } \\
\text { nt } \\
\text { Op2: EntityElement or } \\
\text { EntityContainerEleme } \\
\text { nt }\end{array}$ & $\begin{array}{l}\text { ElmsIn(Op1, Op2) } \\
\text { Or } \\
\text { ChElmsIn(Op1,Op2)Op1 } \\
\text {,Op2) }\end{array}$ \\
\hline : & Select From Set & $\begin{array}{l}\text { Returns the Value found at the } \\
\text { specified 1-based index in the Set Op1. } \\
\text { Example: Select(Int(2),Set- } \\
\text { Str([A,B,C,D])) will return Str(B), the } \\
\text { second String in the set. }\end{array}$ & Any & $\begin{array}{l}\text { Op1: Numericlnteger } \\
\text { Op2: Set (Any Type) }\end{array}$ & Select(Op1, Op2) \\
\hline S & Select SubSet & $\begin{array}{l}\text { Returns the subset of Set Op2 indicated } \\
\text { by the 1-based index values } \\
\text { represented by Set-Int Op1. Invalid } \\
\text { indices are ingored. } \\
\text { Example: }\end{array}$ & Set-Any & $\begin{array}{l}\text { Op1: Set-Int } \\
\text { Op2: Set (Any Type) }\end{array}$ & SelectSubSet(Op1, Op2) \\
\hline
\end{tabular}




\begin{tabular}{|c|c|c|c|c|}
\hline \multicolumn{5}{|c|}{ Expression Definitions } \\
\hline Expression Name & Description & Return Type & Operand Types & Operator Syntax \\
\hline & $\begin{array}{l}\text { SelectSubSet(Set-Int[1,3,4], Set- } \\
\text { Str([A,B,C])) will return Set-Str([A,C]) } \\
\text { (index } 4 \text { is ignored) }\end{array}$ & & & \\
\hline First Occurrence & Returns the First Value in the Set Op1. & Any & Op1: Set (Any Type) & Firstln(Op1) \\
\hline Last Occurrence & Returns the Last Value in the SetOp2. & Any & Op1: Set (Any Type) & Lastln(Op1) \\
\hline Set Union & $\begin{array}{l}\text { Returns the Set Union of the two Set } \\
\text { operands Op1 and Op2 that contains all } \\
\text { of the members of both. } \\
\text { Ex: Union(Set-Num([1.0,2.2]),Set- } \\
\text { Num([2.2, 10, 200.1])) is Set-Num([1.0, } \\
2.2,10,200.1])\end{array}$ & Set (Any Type) & $\begin{array}{l}\text { Op1: Set (Any Type) } \\
\text { Op2: Set (Any Type) } \\
\text { Op1 and Op2 must be } \\
\text { of same set type. }\end{array}$ & Union(Op1, Op2) \\
\hline
\end{tabular}

\section{Complex Test Assertions}

Some Test Assertions cannot be represented using the well-defined Test Assertion Syntax, or require specific instances of entities to be identified rather than every occurrence as defined by the Entity Value-Types. Such Assertions require a textual description of the test that must be performed. To assist in streamlining most of these textual descriptions, a Complex Assertion Syntax is included in this section. This Complex Assertion Syntax does not represent a complete syntax, nor is it necessarily well-defined; its purpose is only to provide a toolset to assist in explaining Complex Test Assertions. The Complex Assertion Syntax is composed of Complex Expressions, Complex ValueTypes, and Complex Procedures. Complex Procedures are operations that are repeated for several Assertions, but do not return a value. The format is: Complex(Description), where Description is composed of Complex Expressions, Complex Value-Types, Complex Procedures, and plain English. Description may also be a message such as "See Note" when the test assertion is too large to be contained in the table, and must be explained in a note or other location.

\section{Complex Expressions and Value-Types}

The Expressions found in this section are used to help clarify Complex Assertions that cannot easily be represented in the Assertion Syntax.

\section{Table 5.6 - Assertion Syntax: Complex Expression Definitions}

\begin{tabular}{|c|c|c|c|c|}
\hline \multicolumn{5}{|c|}{ Complex Expression Definitions } \\
\hline $\begin{array}{c}\text { Expression } \\
\text { Name }\end{array}$ & Description & Return Type & Operand Types & Operator Syntax \\
\hline Parent & $\begin{array}{l}\text { Returns the Parent of the Entity (the } \\
\text { Entity that contains the specified } \\
\text { Entity). }\end{array}$ & GenericEntity & Op1: GenericEntity & Parent(Op1) \\
\hline
\end{tabular}




\begin{tabular}{|l|l|l|l|l|}
\hline Pair & $\begin{array}{l}\text { Returns a set of Entity Pairs that } \\
\text { satisfy the Entity Query. The pair is } \\
\text { represented in the rest of the } \\
\text { Assertion by A,B. }\end{array}$ & $\begin{array}{l}\text { Set } \\
\text { (GenericEntity) }\end{array}$ & Op1: EntityQuery & Pair(Op1) \\
\hline
\end{tabular}

Table 5.7 - Assertion Syntax: Complex Value-Type Definitions

\begin{tabular}{|c|c|c|}
\hline \multicolumn{3}{|c|}{ Complex Value-Type Definitions } \\
\hline Value Type & Valid Values & Syntax \\
\hline GenericEntity & $\begin{array}{l}\text { Any generic entity defined for either encoding: Transaction, } \\
\text { Record, Field, Subfield, Infoltem, or Element. This is a generic } \\
\text { representation that does not indicate a specific entity. }\end{array}$ & GenEntity(VALUE) \\
\hline EntityQuery & $\begin{array}{l}\text { A search query for a specific instance of an Entity. The general } \\
\text { structure of the query is: } \\
\text { P:N in Q ST(condition) } \\
\text { For example, Infoltem: } 2 \text { in Subfield ST(EQ(\{Infoltem\}, Str(1)) } \\
\text { Note that any of the elements of the query are optional, for } \\
\text { example: P:N or P in Q or P ST(condition) or simply P }\end{array}$ & Query(VALUE) \\
\hline
\end{tabular}

\section{Complex Procedures}

The procedures described in this section list common tasks that are repeated for several Complex Assertions. They are not Expressions because they do not return a value.

\section{Table 5.8 - Assertion Syntax: Complex Procedure Definitions}

\begin{tabular}{|c|c|c|c|c|}
\hline \multicolumn{5}{|c|}{ Complex Procedure Definitions } \\
\hline Name & Description & Return Type & Operand Types & Operator Syntax \\
\hline Variable & $\begin{array}{l}\text { Uses the String value as a variable to } \\
\text { represent the containing expression } \\
\text { for the remainder of the Assertion } \\
\text { Text. This is used to avoid repetitions } \\
\text { in the assertion text. }\end{array}$ & None & Op1: String & $\operatorname{Var}(0 p 1)($ Expression) \\
\hline For Loop & $\begin{array}{l}\text { Evaluates the containing expressions } \\
\text { for each value in the specified range } \\
\text { of the operator values (Op1 to Op2). X } \\
\text { represents the current value in the } \\
\text { loop. }\end{array}$ & None & $\begin{array}{l}\text { Op1: Numericlnteger } \\
\text { Op2: NumericInteger }\end{array}$ & $\begin{array}{l}\text { ForX(Op1, Op2) } \\
\text { (Expressions) }\end{array}$ \\
\hline For Each Loop & $\begin{array}{l}\text { The For Each Loop evaluates the } \\
\text { containing expressions for each value } \\
\text { in the set Operator. } X \text { represents the } \\
\text { current value in the loop. For nested } \\
\text { loops, } X N \text { represents the current value } \\
\text { of the loop, where } N \text { is the level of } \\
\text { nesting. }\end{array}$ & None & Op1: Set (Any Type) & $\begin{array}{l}\text { ForEachX(Op1) } \\
\text { (Expressions) }\end{array}$ \\
\hline Next Iteration & $\begin{array}{l}\text { Only for use in For Each Loop: } \\
\text { references the next occurrence of } X \text {. }\end{array}$ & None & None & $\operatorname{Next}(X)$ \\
\hline Previous Iteration & $\begin{array}{l}\text { Only for use in For Each Loop: } \\
\text { references the previous occurrence of } \\
X \text {. }\end{array}$ & None & None & Previous(X) \\
\hline
\end{tabular}




\section{Field Definitions and Structures (Traditional Encoding)}

The test assertion syntax represents all field types as a field that contains a list of one or more subfields, each of which contains a list of one or more information items. Fig. 5.9 is a representation of how each field type is represented by the test assertion syntax:

- Single Information Item: Field with one subfield containing one information item.

- Multiple Information Items: Field with one subfield containing multiple information items.

- Subfields Repeating Sets of Information Items: Field with one or more subfields, each containing sets of one or more information items.

- Subfields Repeating Values: Field with one or more subfields, each containing one information item.

Figure 5.9 - Generic AN-2013 Field Structure



Unless otherwise stated, the Test Assertion Syntax expresses all field structures using the Traditional notation of record type and field number (e.g., 1.001) as well as subfield and information item indices when appropriate. However, the NIEM-XML encoding has no concept of subfields or information items. Instead, the XML encoding uses sub elements. Annex G of the AN-2013 standard - NIEM-conformant Encoding Rules - can be used to translate the listed values for Traditional structures to the XML equivalent. In some cases the tables of requirements and assertions list the XML element names when necessary for clarifying an assertion.

\section{Tables of requirements and assertions format}

\section{Table Layout}

A Requirement is related to one or more Test Assertions. Therefore, a single Requirement may require more than one test assertion row of a table. To represent this association (from left to right), a Requirement is listed first, followed by the related assertion(s). Test notes may be included for any specific assertion to help clarify its meaning when necessary. Information contained in the table is described by the table column headers later in this section.

The AN-2013 contains requirements for several biometric record types, data conventions, and data encodings contained in various clauses, tables, figures, and annexes throughout the standard. The complex and detailed nature of the AN-2013 standard, including the variety of ways that requirements are specified, increases the chance that certain requirements may be stated in more than one section of the standard. In such cases, the table of requirements and assertions would indicate that the requirement is a duplicate requirement. The AN-2013 section numbers where the requirement is specified would be indicated. If there are too many to list, the requirement would be labeled a generic requirement, where other sections define it with more clarity and detail. For all duplicate or generic requirements, no assertions would be defined. The columns of the table 
dedicated to assertion information may be merged and filled with a notification of the duplicate requirement. The format would be as follows, where Optional Message is any text that helps describe why the requirement is a duplicate or generic:

- Duplicate Requirement. Optional Message. See AN-2013 Section:

- Generic Requirement. Optional Message. Specific instances are defined more precisely in several sections of AN-2013.

For an example of the table layout specified by the CTMF, see Annex B.

Table Headers

The following describe the headings for the tables of requirements and assertions format:

- Requirement \# and ID: Includes a unique AN-2013 requirement number and a unique identifier for the requirement and associated assertion or set of assertions. For Record Type requirements, the Requirement \# is in the form RTN.M, where N is the Record Type and M is the sequential number of the requirement (for requirements in the annexes the form is AN followed the Annex letter). For sections not associated with a record type and annexes, the prefix is SEC followed by the section number. If additional requirements must be entered in the future, the number M may change. The Requirement ID provides reference to the type of requirement (e.g., transaction, record, or field), and is in the form of "Type: Description" where type may be "Transaction", "Record", or "Field". For requirements found in Annex B of the AN-2013 standard, the Requirement ID is preceded by "Traditional-". For requirements found in Annexes C and G of the AN-2013 standard, the Requirement ID is preceded by "NIEM-".

- Ref. in Base Std. (Reference in Base Standard): Identifies the clause (or section) where the requirement is included in the $\mathrm{AN}-2013$ standard. In some cases the reference includes additional information such as a Table number.

- Requirement Summary: Provides a summary of the requirement detailed as textual information or an interpretation of the requirement in the standard. It provides the essentials of the requirement but may not provide all the text necessary to understand it.

- Level: Indicates whether Level 1 or Level 2 conformance testing is required to address the assertion identified in the Assertion ID column of the same row. Level 3 conformance tests are indicated only when necessary to show that the requirement is not currently testable or addressed.

- Assertion ID: Provides an identifier of a specific test assertion within the set of test assertions associated with a requirement.

- Test Assertion: Provides, whenever possible, a mathematical equation or a procedure using the language specified by the Assertion Syntax.

- Notes: Contains the ID of the test note, in the form $\mathrm{t} \#$ \#. Test notes provide additional information related to the assertion and are included below the tables.

- Imp. Required (Implementation Required): The Imp. Required column indicates whether or not the assertion must be supported in the Imp. Support column. The format is CondCodeEntity, where:

\section{Entity:}


This indicates the entity (Field, Subfield, etc.) that is the primary subject of the assertion. The assertion must be tested for every instance of this entity in the transaction. This is particularly useful for assertions that contain more than one entity (generally Level-2 assertions). The syntax is any Entity type in Table 5.1 (Assertion Syntax: Value-Type Definitions Value-Types) defined in the Assertion Syntax.

\section{Cond Code:}

This indicates the Cond Code (as specified in AN-2013) of the Entity that is the subject of the assertion. The Cond Code indicates whether or not the entity must be present. For XML Elements that do not relate exactly one-to-one with Traditional constructs, the Cond Code is $\mathrm{M}$ (Mandatory) if the Cardinality is greater than 0 and $\mathrm{O}$ (Optional) otherwise. All assertions associated with entities that have Mandatory Cond Codes must be claimed under Implementation Support. Note that the Cond Code of an entity is dependent upon the inclusion of the parent record or field in the IUT. For example, Field 10.001 with Cond Code $\mathrm{M}$ is required to be present (and therefore its related assertions are required to be claimed) only if a Type-10 Record is included. As another example, 1.013-DNM is mandatory only if the optional field 1.013 is included. It should also be noted that the Cond Code only applies if the assertion is related to the transaction's encoding as indicated by the Enc. (Encoding) column. The Cond Code values are:

- M: Mandatory - entity must be present, assertion must be claimed

○ O: Optional - entity not required to be present, assertion not required to be claimed

- D: Dependent - presence of entity is dependent upon certain conditions specified in the AN-2013 standard. If the entity is required to be present, the assertion must be claimed.

- M介: Mandatory within the optional field/subfield - entity must be present if the containing field/subfield is present, and the assertion must then be claimed.

○ O介: Optional within the optional field/subfield - entity is not required to be present, even if the containing field/subfield is present. The assertion is not required to be claimed.

Note: For Optional or Dependent Cond Codes, if the entity is present in the IUT (although it is not required to be), the related assertion must be claimed.

\section{Example:}

M-Fld(10.001). The subject of the assertion is Field 10.001 with Cond Code M, meaning that the assertion must be tested for every instance of Field 10.001. This is a Mandatory field (M), indicating that this assertion must be claimed given that Record Type-10 is present in the IUT.

- Imp. Support (Implementation Support): Denotes a supplier's implementation support of a particular assertion ("Y"/"N"). A note can follow the table when providing more details of implementation support (or the lack of it) is required. For assertions with Mandatory Imp. Required values, the Imp. Support should be Y given that the parent Record or Field is also supported.

- Supported Range: Indicates a range of values supported, especially when it is different than the full range of values specified in the standard. When an information item is specified as a single value, or does not address a range of values, a N/A should be used.

- Test Result: This column is used to denote the test results. The result is one of "Pass", "Fail", or "Warning". Explanatory notes can be added below the table, for example when a 
Warning is given. The result is the value provided by evaluating the test described in the Test Assertion column.

- Enc. - (Encoding): This table header indicates which assertions differ (in values required or conditions) between Traditional and NIEM encoding. This table header does not indicate which assertions are addressed by the XML Schema and which will need to be addressed in code. Valid values are:

- T: The assertion only applies to the Traditional encoding as described in Annex B of AN-2013.

○ X: The assertion only applies to the NIEM-conformant (XML) encoding as described in Annex C of AN-2013.

- B: The assertion is applicable to both Traditional and NIEM (XML) encoding.

- Following the conventions in the AN-2013 standard, test Assertions are expressed using constructs (fields, records, etc.) found in Traditional encoding (such as 1.002). The same assertion applies for the XML elements that correspond to the Traditional constructs. For example, 10.006 in Traditional Encoding corresponds to XML Element < biom:ImageHorizontalLineLengthPixelQuantity>. Annex G of the AN-2013 provides a mapping between Traditional and XML encodings.

\subsection{Claim of Supported Test Assertions}

The table format for requirements and assertions provides the means for the developers of implementations under test (IUT) to claim in the tables the list of all the assertions supported.

This information is useful to the IUT supplier as a checklist on the content of their implementations and also useful to testing laboratories that would evaluate conformance of these IUTs against the supplier's claims. Two columns in the tables are included to provide this information: Implementation Support column (YES/NO/Partial) and Supported Range column (if Implementation Support is "Partial", the supported range should be provided).

The minimum implementation requirements are documented in Annex A. The Implementation Required (Imp. Required) column indicates the entity related to each assertion, and the Cond Code for that entity. A Mandatory Cond Code indicates that the entity must be present, and therefore the assertion must be claimed. Such Cond Codes only apply if the containing Record or Field is also present - for example, 10.001 is Mandatory, but only if the IUT contains a Record Type-10. Regardless of the supplier claims, if an entity (Field, Subfield, etc.) is included in the IUT, the test assertions related to that entity will be tested and should be reported by a conformance test tool.

It is recommended that if the IUTs are sent to a testing laboratory, the IUT provider submit the information below to the laboratory:

- Provider name

- Provider address

- Transaction identifier

- Transaction version number

- Additional implementation information (optional)

- Submission date 
- For each claimed Record Type, provide the Record Type number and whether or not (Yes or No) there are any known deviations from (or exceptions to) the requirements found in the base standard and identified in the Conformance Testing Methodology for the associated Record Types in the IUT. For specific exceptions, the Implementation Support column of the tables of requirements and assertions can be used to indicate the difference on a per-assertion basis. In addition, if the deviation is general and applies to the entire Record Type, a description should be provided. This option is useful for cases where there have been modifications to the base standard that are not reflected in the conformance testing methodology, where the IUT provider believes there is a defect in the base standard or conformance testing methodology, and other instances where the implementation does not fully conform to the AN-2013 standard requirements.

The testing laboratory may use testing tools that implement this CTMF and any the test assertions included in any derivative conformant publications (such as those which document additional requirements) to provide a determination of the level of conformance of the IUT to the AN-2013 standard. 


\section{Annex A: Minimum Support for AN-2013 Record Types and Interrelated Fields}

\section{A.1 Minimum Conformance}

This document includes conformance test assertions for all the transaction-related requirements specified in AN-2013. This document does not include test assertions for Record Types other than Record Type 1.

This section identifies the AN-2013 requirements and the conformance test assertions that are required for every transaction according to the terms specified in the AN-2013 standard. At a minimum, AN-2013 requires that:

- the transaction adheres to its specified encoding (Traditional or NIEM-XML) requirements

- the transaction includes one and only one Record Type-1

- Record Type-1 is encoded exclusively in 7-bit ASCII (for Traditional Encoding)

- Record Type-1 is conformant to the requirements specified for its fields, subfields, and information items.

- All mandatory fields, subfields, and information items in Record Type-1 must be present (with data), and the requirements for those entities must be met.

- Optional and dependent fields, subfields, and information items that are present in Record Type-1 must be conformant to the requirements specified for those entities.

- the transaction includes at least one other record of a type other than Record Type-1

- the transaction does not include deprecated or reserved record types or fields

The AN-2013 requirements listed above constitute what is indicated in this document as the minimal conformance for any AN-2013 transaction, according to the requirements specified by AN-2013. Note, however, that minimal conformance is silent regarding the requirements for individual Records other than Record Type-1. For example, a minimally conformant AN-2013 transaction may include a non-conformant Record Type-10.

\section{A.2 Interrelated Field Support}

Section 7: Information Common to Several Record Types in the AN-2013 standard includes requirements for fields that are common among various record types. These requirements are contained in Annex C, in the table of requirements and assertions associated with Section 7 of the AN-2013 standard. Below is a list of the common fields with requirements specified in Annex C of this CTMF.

Table A.1 - AN-2013 Interrelated Field Support 


\begin{tabular}{|c|l|l|}
\hline \multicolumn{2}{|l|}{ Support for AN-2013 Interrelated Fields } \\
\hline Number & Field Contents & Support \\
\hline xx.001 & Record header & All Record Types. See Field: xx.001-Record Header \\
\hline xx.002 & Information designation character / IDC & All Record Types except Record Type-1. See Field: xx.002-IDC \\
\hline xx.995 & Associated Context / ASC & $\begin{array}{l}\text { Record Types } 10 \text { and above, not including 21 and 98. See Field: xx.995-ASC through Field: } \\
\text { xx.995-ASC-ASP }\end{array}$ \\
\hline xx.997 & Source Representation / SOR & $\begin{array}{l}\text { Record Types } 10 \text { and above, not including 18, 21, and 98. See Field: xx.997-SOR through } \\
\text { Field: xx.997-SOR-RSP }\end{array}$ \\
\hline xx.016 & Segments / SEG & Record Types 20 and 21. See Field: xx.997-SOR-RSP and Field: xx.995-ASC-ASP \\
\hline xx.021 & SRN, ACN & Record Types 20 and 21. See Field: xx.997-SOR-SRN and Field: xx.995-ASC-ACN \\
\hline
\end{tabular}




\section{Annex B: Sample Requirement and Assertion Table Format}

This section describes the layout of the table-based requirements and assertions format required by the CTMF.

Figure B.1 - Sample Requirements and Assertions Table

\begin{tabular}{|c|c|c|c|c|c|c|c|c|c|c|c|}
\hline Req. \# - ID & $\begin{array}{c}\text { Red. In } \\
\text { Base } \\
\text { Std. }\end{array}$ & $\begin{array}{l}\text { Requirement } \\
\text { Summary }\end{array}$ & $\begin{array}{l}\text { L } \\
\text { e } \\
\text { v } \\
\text { e } \\
\text { I }\end{array}$ & $\begin{array}{l}\text { Assertion } \\
\text { ID }\end{array}$ & $\begin{array}{c}\text { Test } \\
\text { Assertion }\end{array}$ & $\begin{array}{l}\mathbf{N} \\
\mathbf{0} \\
\mathrm{t} \\
\mathrm{e} \\
\mathrm{s}\end{array}$ & $\begin{array}{l}\text { Imp. } \\
\text { Required }\end{array}$ & $\begin{array}{l}\text { Imp. } \\
\text { Support }\end{array}$ & $\begin{array}{l}\text { Supported } \\
\text { Range }\end{array}$ & $\begin{array}{c}\text { Test } \\
\text { Result }\end{array}$ & $\begin{array}{l}\mathrm{E} \\
\mathrm{n} \\
\mathrm{c} \\
\text {. }\end{array}$ \\
\hline \multirow[t]{3}{*}{$\begin{array}{c}\text { RTX.1 - } \\
\text { Requirement } \\
\text { ID }\end{array}$} & \multirow[t]{3}{*}{$\begin{array}{l}\text { N.N, } \\
\text { Table Z }\end{array}$} & \multirow[t]{3}{*}{$\begin{array}{l}\text { Requirement text: verbatim from the base } \\
\text { standard or a summary. }\end{array}$} & 1 & $\begin{array}{l}\text { Assertion ID } \\
\quad 1\end{array}$ & $\begin{array}{l}\text { Assertion summary written using the Test } \\
\text { Assertion Syntax - this one is for Traditional } \\
\text { encoding }\end{array}$ & & M-Fld(1.001) & & & Warning & $\mathrm{T}$ \\
\hline & & & 1 & $\begin{array}{l}\text { Assertion ID } \\
\quad 2\end{array}$ & $\begin{array}{l}\text { Assertion summary written using the Test } \\
\text { Assertion Syntax - this one is for XML encoding }\end{array}$ & $\mathrm{t} \# \#$ & O- & & & & $x$ \\
\hline & & & 2 & $\begin{array}{l}\text { Assertion ID } \\
\mathrm{N}\end{array}$ & $\begin{array}{l}\text { Assertion summary written using the Test } \\
\text { Assertion Syntax - one or more assertions are } \\
\text { listed per Requirement }\end{array}$ & & & & & & B \\
\hline $\begin{array}{l}\text { RTX.2- } \\
\text { Requirement } \\
\text { ID2 }\end{array}$ & M.M & $\begin{array}{l}\text { Requirement text: verbatim from the base } \\
\text { standard or a summary. }\end{array}$ & 1 & $\begin{array}{l}\text { Assertion ID } \\
\quad 1\end{array}$ & $\begin{array}{l}\text { Assertion summary written using the Test } \\
\text { Assertion Syntax - this one is for both encodings }\end{array}$ & & & & & & B \\
\hline
\end{tabular}




\section{Annex C: Tables of Requirements and Assertions}

The CTMF allows for all requirements and assertions to be documented for AN-2013. The full range of requirements and assertions are not included in this publication. The requirements necessary for minimum conformance as indicated in Annex A are included as are requirements for data formats, encodings, and those related to several record types. This Annex lists the tables of requirements and assertions common to most AN-2013 transactions; the AN-2013 requirement types and the reason for their inclusion are provided below:

\section{AN-2013 Section 5: Data Conventions}

Requirements for data conventions describe the structure and ordering of constructs that make up all AN-2013 transactions. Requirements for deprecated Record Types 3, 5, and 6 are also included to check for nonexistence of these Record Types. Additionally an assertion is specified that checks for the nonexistence of reserved Record Types 22 through 97.

\section{AN-2013 Section 7: Information Common to Several Record Types}

Information common to several record types refers to fields and other constructs that are defined once in the AN-2013 standard, and repeated for several record types. While these requirements may not be relevant to every transaction, a portion of these requirements are relevant to a large number of transactions.

AN-2013 Section 8.1 Record Type-1: Transaction information record

One and only one instance of Record Type-1 is required to be included in every AN-2013 transaction. The requirements associated with mandatory fields, subfields, information items, and XML Elements in Record Type-1 must be met for every AN-2013 transaction. Note that if any optional construct is present in any transaction, the defined requirements for those constructs are mandatory for conformance. An optional construct does not indicate an optional requirement.

\section{AN-2013 Annex B: Traditional Encoding}

Traditional encoding specifies requirements that describe the general makeup of any traditionally-encoded AN-2013 transaction.

\section{AN-2013 Annex C: NIEM Conformant encoding}

NIEM conformant encoding specifies requirements that describe the general makeup of any XML-encoded AN-2013 transaction.

\section{AN-2013 Annex G: Mapping to the NIEM IEPD}

Mapping to the NIEM IEPD provides the information necessary to interpret requirements represented in Traditional Encoding notation for XML-encoded transactions. The mapping indicates instances where the relationship between Traditional constructs (fields, subfields, etc.) is not one-to-one with XML elements. 
Table C.1 - Assertions for Transaction-related Requirements

\begin{tabular}{|c|c|c|c|c|c|c|c|c|c|c|c|}
\hline Req. \# - ID & $\begin{array}{l}\text { Ref.in } \\
\text { Base } \\
\text { Std. }\end{array}$ & $\begin{array}{l}\text { Requirement } \\
\text { Summary }\end{array}$ & $\begin{array}{l}\text { L } \\
\text { e } \\
\mathbf{v} \\
\text { e } \\
\text { l }\end{array}$ & $\begin{array}{l}\text { Assertion } \\
\text { ID }\end{array}$ & $\begin{array}{c}\text { Test } \\
\text { Assertion }\end{array}$ & $\begin{array}{l}\mathbf{N} \\
\mathbf{o} \\
\mathbf{t} \\
\mathrm{e} \\
\mathrm{S}\end{array}$ & $\begin{array}{l}\text { Imp. } \\
\text { Required }\end{array}$ & $\begin{array}{l}\text { Imp. } \\
\text { Support }\end{array}$ & $\begin{array}{l}\text { Supporte } \\
\text { d Range }\end{array}$ & $\begin{array}{c}\text { Test } \\
\text { Result }\end{array}$ & $\begin{array}{l}\mathbf{E} \\
\mathbf{n} \\
\mathbf{c}\end{array}$ \\
\hline \multicolumn{12}{|c|}{ Transaction-related Requirements } \\
\hline \multirow[t]{3}{*}{$\begin{array}{l}\text { TX.1 - Tran } \\
\text { saction: } \\
\text { Required } \\
\text { Record } \\
\text { Types }\end{array}$} & \multirow[t]{3}{*}{$\begin{array}{l}\text { 5.1, } \\
\text { 5.3.1, } \\
\text { Annex G }\end{array}$} & \multirow{3}{*}{$\begin{array}{l}\text { There may be multiple records in a } \\
\text { transaction of each record type other than } \\
\text { Type- } 1 \text {. The only required record Type is } \\
\text { Type-1, which is used to describe the } \\
\text { transaction. There shall be at least one } \\
\text { other record type from Table } 3 \\
\text { accompanying a Record Type-1. } \\
\text { Transmissions to be exchanged are } \\
\text { required to contain one and only one Type- } \\
1 \text { record per transaction. } \\
\text { Itl:PackageInformationRecord Cardinality } \\
1 . .1\end{array}$} & 1 & $\begin{array}{l}\text { Transaction } \\
\text {-Type-1- } \\
\text { Required }\end{array}$ & $\begin{array}{l}\text { EQ } \\
( \\
\operatorname{Count}(\operatorname{Recs}(\operatorname{Int}(1))), \\
\operatorname{Int}(1)\end{array}$ & & $\begin{array}{c}\text { M- } \\
\text { Transaction }\end{array}$ & & & & $\mathrm{T}$ \\
\hline & & & 1 & $\begin{array}{l}\text { NIEM- } \\
\text { Transaction } \\
- \\
\text { PackageInf } \\
\text { ormationRe } \\
\text { cord- } \\
\text { Required }\end{array}$ & $\begin{array}{l}\text { EQ } \\
\text { Count(Recs(Str(itl:PackageInformationRecord))), } \\
\text { Int(1) } \\
)\end{array}$ & & $\begin{array}{c}\text { M- } \\
\text { Transaction }\end{array}$ & & & & $\mathrm{X}$ \\
\hline & & & 1 & $\begin{array}{l}\text { Transaction } \\
\text {-Required- } \\
\text { Additional- } \\
\text { Record }\end{array}$ & $\begin{array}{l}\text { GT } \\
( \\
\text { Count(Recs), } \\
\text { Int(1) } \\
)^{(1)}\end{array}$ & & $\begin{array}{c}\text { M- } \\
\text { Transaction }\end{array}$ & & & & B \\
\hline $\begin{array}{l}\text { TX.2 - Tran } \\
\text { saction: } \\
\text { Single } \\
\text { Subject }\end{array}$ & 5.1 & $\begin{array}{l}\text { All records in a transaction shall pertain to } \\
\text { a single subject. Biometric data used to } \\
\text { identify another individual requires a } \\
\text { separate transaction. }\end{array}$ & 3 & $\begin{array}{l}\text { Transaction } \\
\text {-Single } \\
\text { Subject }\end{array}$ & $\begin{array}{l}\text { ReturnResult } \\
\text { ( } \\
\text { Result } \\
\text { ( } \\
\text { Warning(Unchecked Level } 3 \text { - All records shall } \\
\text { pertain to a single subject.) } \\
\text { ) }\end{array}$ & & $\begin{array}{c}\text { M- } \\
\text { Transaction }\end{array}$ & & & & B \\
\hline $\begin{array}{l}\text { TX.3 - Tran } \\
\text { saction: } \\
\text { Records } \\
\text { Transmitted } \\
\text { Together }\end{array}$ & 5.1 & $\begin{array}{l}\text { All of the records belonging to a single } \\
\text { transaction shall be transmitted together. }\end{array}$ & 3 & $\begin{array}{l}\text { Transaction } \\
\text {-Records } \\
\text { Together }\end{array}$ & $\begin{array}{l}\text { ReturnResult } \\
\text { ( } \\
\text { Result } \\
\text { ( } \\
\text { Warning(Unchecked Level } 3 \text { - All records } \\
\text { belonging to a single transaction shall be } \\
\text { transmitted together.) } \\
\text { ) }\end{array}$ & & $\begin{array}{c}\text { M- } \\
\text { Transaction }\end{array}$ & & & & B \\
\hline $\begin{array}{l}\text { TX.4 - Tran } \\
\text { saction: Size }\end{array}$ & 5.2 & $\begin{array}{l}\text { The upper limit of } 1000 \text { records is } \\
\text { maintained in this version of the standard } \\
\text { to ensure backward compatibility with the }\end{array}$ & 1 & $\begin{array}{l}\text { Transaction } \\
\quad-\text { Size }\end{array}$ & $\begin{array}{l}\text { LTE } \\
\text { ( Count(Recs), }\end{array}$ & & $\begin{array}{c}\text { M- } \\
\text { Transaction }\end{array}$ & & & & B \\
\hline
\end{tabular}




\begin{tabular}{|c|c|c|c|c|c|c|c|c|c|c|c|}
\hline Req. \# - ID & $\begin{array}{l}\text { Ref.in } \\
\text { Base } \\
\text { Std. }\end{array}$ & $\begin{array}{l}\text { Requirement } \\
\text { Summary }\end{array}$ & $\begin{array}{l}\text { L } \\
\text { e } \\
\text { v } \\
\text { e } \\
\text { l }\end{array}$ & $\begin{array}{l}\text { Assertion } \\
\text { ID }\end{array}$ & $\begin{array}{c}\text { Test } \\
\text { Assertion }\end{array}$ & $\begin{array}{l}\mathbf{N} \\
\mathbf{o} \\
\mathbf{t} \\
\mathbf{e} \\
\mathbf{S}\end{array}$ & $\begin{array}{c}\text { Imp. } \\
\text { Required }\end{array}$ & $\begin{array}{c}\text { Imp. } \\
\text { Support }\end{array}$ & $\begin{array}{l}\text { Supporte } \\
\text { d Range }\end{array}$ & $\begin{array}{c}\text { Test } \\
\text { Result }\end{array}$ & $\begin{array}{l}\mathbf{E} \\
\mathbf{n} \\
\mathbf{c} \\
.\end{array}$ \\
\hline \multicolumn{12}{|c|}{ Transaction-related Requirements } \\
\hline & & 2007 version. & & & $\operatorname{Int}^{\operatorname{Int}(1000)}$ & & & & & & \\
\hline \multirow[t]{2}{*}{$\begin{array}{l}\text { TX.5 - Tran } \\
\text { saction: } \\
\text { Reserved } \\
\text { Records }\end{array}$} & \multirow[t]{2}{*}{$\begin{array}{c}5.3 \\
\text { Table } 3\end{array}$} & \multirow[t]{2}{*}{ 22-97 reserved for future use. } & 1 & $\begin{array}{l}\text { Transaction } \\
\text {-Records } \\
\text { Reserved }\end{array}$ & $\begin{array}{l}\text { EQ } \\
( \\
\operatorname{Count}(\operatorname{Recs}(\operatorname{Set}-\operatorname{Int}(22 \text { to } 97))) \text {, } \\
\operatorname{Int}(0)\end{array}$ & & $\begin{array}{c}\text { M- } \\
\text { Transaction }\end{array}$ & & & & $\mathrm{T}$ \\
\hline & & & 1 & $\begin{array}{l}\text { NIEM- } \\
\text { Transaction } \\
\text {-Records } \\
\text { Reserved }\end{array}$ & $\begin{array}{l}\text { ReturnResult } \\
\text { ( } \\
\text { Result } \\
\text { Pass(Element names are not defined for reserved } \\
\text { records. Invalid records will fail schema } \\
\text { validation.) } \\
\text { ) }\end{array}$ & & $\begin{array}{c}\text { M- } \\
\text { Transaction }\end{array}$ & & & & $\mathrm{X}$ \\
\hline \multirow[t]{2}{*}{$\begin{array}{l}\text { TX.6 - Tran } \\
\text { saction: } \\
\text { Type1- } \\
\text { Record_Firs } \\
\text { t }\end{array}$} & \multirow[t]{2}{*}{5.3 .1} & \multirow[t]{2}{*}{$\begin{array}{l}\text { The Type- } 1 \text { record shall always be the first } \\
\text { record within the transaction. }\end{array}$} & 1 & $\begin{array}{l}\text { Transaction } \\
\text {-Type1- } \\
\text { First }\end{array}$ & $\begin{array}{l}\text { EQ } \\
( \\
\operatorname{RecType}(\text { FirstIn(Recs) }) \\
\text { Int(1) } \\
)\end{array}$ & & $\begin{array}{c}\text { M- } \\
\text { Transaction }\end{array}$ & & & & $\mathrm{T}$ \\
\hline & & & 1 & $\begin{array}{l}\text { NIEM- } \\
\text { Transaction } \\
\text {-Type1- } \\
\text { First }\end{array}$ & $\begin{array}{l}\text { EQ } \\
\text { ( } \\
\text { ElmName(FirstIn(Recs)), } \\
\text { Str(itl:PackageInformationRecord) } \\
\text { ) }\end{array}$ & & $\begin{array}{l}\text { M- } \\
\text { Transaction }\end{array}$ & & & & $\mathrm{X}$ \\
\hline \multirow[t]{2}{*}{$\begin{array}{l}\text { TX.7 - Tran } \\
\text { saction: } \\
\text { Type3- } \\
\text { Deprecated }\end{array}$} & \multirow[t]{2}{*}{$\begin{array}{c}5.3 .3 \\
5.4 \\
\text { Table } 3 . \\
8.3\end{array}$} & \multirow{2}{*}{$\begin{array}{l}\text { Record Type- } 3 \text { shall not be contained in } \\
\text { transactions conforming to this version of } \\
\text { the standard. } \\
\text { No instances of Record Type- } 3 \text { shall be } \\
\text { included in a transaction conformant with } \\
\text { this version of the standard. } \\
\text { Deprecated records for this version are } \\
\text { Record Types } 3,5 \text { and } 6 \text {. }\end{array}$} & 1 & $\begin{array}{l}\text { Transaction } \\
\text {-Type3- } \\
\text { Zero } \\
\text { Occurrence } \\
\text { s }\end{array}$ & EQ(Count $(\operatorname{Recs}(\operatorname{Int}(3)), \operatorname{Int}(0))$ & & $\begin{array}{c}\text { M- } \\
\text { Transaction }\end{array}$ & & & & $\mathrm{T}$ \\
\hline & & & 1 & $\begin{array}{l}\text { NIEM- } \\
\text { Transaction } \\
\text {-Type3- } \\
\text { Zero } \\
\text { Occurrence } \\
\text { s }\end{array}$ & $\begin{array}{l}\text { ReturnResult } \\
\text { ( } \\
\text { Result } \\
\text { ( } \\
\text { Pass(Deprecated Records are not defined for } \\
\text { NIEM-XML; invalid Records will fail Schema } \\
\text { validation) } \\
\text { ) }\end{array}$ & & $\begin{array}{c}\text { M- } \\
\text { Transaction }\end{array}$ & & & & $\mathrm{X}$ \\
\hline
\end{tabular}




\begin{tabular}{|c|c|c|c|c|c|c|c|c|c|c|c|}
\hline Req. \# - ID & $\begin{array}{l}\text { Ref.in } \\
\text { Base } \\
\text { Std. }\end{array}$ & $\begin{array}{c}\text { Requirement } \\
\text { Summary }\end{array}$ & $\begin{array}{l}\text { L } \\
\text { e } \\
\text { v } \\
\text { e } \\
\text { l }\end{array}$ & $\begin{array}{l}\text { Assertion } \\
\text { ID }\end{array}$ & $\begin{array}{c}\text { Test } \\
\text { Assertion }\end{array}$ & $\begin{array}{l}\mathbf{N} \\
\mathbf{o} \\
\mathbf{t} \\
\mathbf{e} \\
\mathbf{S}\end{array}$ & $\begin{array}{c}\text { Imp. } \\
\text { Required }\end{array}$ & $\begin{array}{c}\text { Imp. } \\
\text { Support }\end{array}$ & $\begin{array}{l}\text { Supporte } \\
\text { d Range }\end{array}$ & $\begin{array}{c}\text { Test } \\
\text { Result }\end{array}$ & $\begin{array}{l}\mathbf{E} \\
\mathbf{n} \\
\mathbf{c} \\
\text {. }\end{array}$ \\
\hline \multicolumn{12}{|c|}{ Transaction-related Requirements } \\
\hline \multirow[t]{2}{*}{$\begin{array}{l}\text { TX.8 - Tran } \\
\text { saction: } \\
\text { Type5- } \\
\text { Deprecated }\end{array}$} & \multirow[t]{2}{*}{$\begin{array}{c}\text { 5.3.5, } \\
5.4 \\
\text { Table } 3 \\
8.5\end{array}$} & \multirow{2}{*}{$\begin{array}{l}\text { Record Type- } 5 \text { shall not be contained in } \\
\text { transactions conforming to this version of } \\
\text { the standard. } \\
\text { No instances of Record Type- } 5 \text { shall be } \\
\text { included in a transaction conformant with } \\
\text { this version of the standard. } \\
\text { Deprecated records for this version are } \\
\text { Record Types } 3,5 \text { and } 6 \text {. }\end{array}$} & 1 & $\begin{array}{c}\text { Transaction } \\
\text {-Type5- } \\
\text { Zero } \\
\text { Occurrence } \\
\text { s }\end{array}$ & $\begin{array}{l}\text { EQ } \\
( \\
\operatorname{Count}(\operatorname{Recs}(\operatorname{Int}(5))) \text {, } \\
\operatorname{Int}(0) \\
)\end{array}$ & & $\begin{array}{c}\text { M- } \\
\text { Transaction }\end{array}$ & & & & $\mathrm{T}$ \\
\hline & & & 1 & $\begin{array}{c}\text { NIEM- } \\
\text { Transaction } \\
\text {-Type5- } \\
\text { Zero } \\
\text { Occurrence } \\
\text { s }\end{array}$ & $\begin{array}{l}\text { ReturnResult } \\
\text { ( } \\
\text { Result } \\
\text { ( } \\
\text { Pass (Deprecated Records are not defined for } \\
\text { NIEM-XML, but invalid Records will fail Schema } \\
\text { validation) } \\
\text { ) }\end{array}$ & & $\begin{array}{c}\text { M- } \\
\text { Transaction }\end{array}$ & & & & $\mathrm{X}$ \\
\hline \multirow[t]{2}{*}{$\begin{array}{l}\text { TX.9 - Tran } \\
\text { saction: } \\
\text { Type6- } \\
\text { Deprecated }\end{array}$} & \multirow[t]{2}{*}{$\begin{array}{c}\text { 5.3.6, } \\
5.4, \\
\text { Table } 3 \\
8.6\end{array}$} & \multirow{2}{*}{$\begin{array}{l}\text { Record Type- } 6 \text { shall not be contained in } \\
\text { transactions conforming to this version of } \\
\text { the standard. } \\
\text { No instances of Record Type- } 6 \text { shall be } \\
\text { included in a transaction conformant with } \\
\text { this version of the standard. } \\
\text { Deprecated records for this version are } \\
\text { Record Types } 3,5 \text { and } 6 \text {. }\end{array}$} & 1 & $\begin{array}{c}\text { Transaction } \\
\text {-Type6- } \\
\text { Zero } \\
\text { Occurrence } \\
\text { s }\end{array}$ & $\begin{array}{l}\text { EQ } \\
( \\
\operatorname{Count}(\operatorname{Recs}(\operatorname{Int}(6)), \\
\operatorname{Int}(0) \\
)\end{array}$ & & $\begin{array}{c}\text { M- } \\
\text { Transaction }\end{array}$ & & & & $\mathrm{T}$ \\
\hline & & & 1 & $\begin{array}{l}\text { NIEM- } \\
\text { Transaction } \\
\text {-Type6- } \\
\text { Zero } \\
\text { Occurrence } \\
\text { s }\end{array}$ & $\begin{array}{l}\text { ReturnResult } \\
( \\
\text { Result } \\
\text { ( } \\
\text { Pass (Deprecated Records are not defined for } \\
\text { NIEM-XML, but invalid Records will fail Schema } \\
\text { validation) } \\
\text { ) } \\
\text { ) }\end{array}$ & & $\begin{array}{c}\text { M- } \\
\text { Transaction }\end{array}$ & & & & $\mathrm{X}$ \\
\hline $\begin{array}{c}\text { TX.10 - Tra } \\
\text { nsaction: } \\
\text { Reserved } \\
\text { Character } \\
\text { Types }\end{array}$ & 5.5 & $\begin{array}{l}\text { The special characters "STX", "ETX", } \\
\text { "FS", "GS", "RS", and "US" are reserved } \\
\text { and shall not be included in any data } \\
\text { (except data marked as character type B). }\end{array}$ & 1 & $\begin{array}{l}\text { Transaction } \\
\text {-Reserved } \\
\text { Character } \\
\text { Types }\end{array}$ & $\begin{array}{l}\text { ReturnResult } \\
\text { ( } \\
\text { Result } \\
\text { ( } \\
\text { Pass(Character Type assertions are performed on } \\
\text { all data. These assertions test for the presence of } \\
\text { reserved characters. Refer to the individual tests } \\
\text { on data to determine the results.) } \\
\text { ) }\end{array}$ & & $\begin{array}{c}\text { M- } \\
\text { Transaction }\end{array}$ & & & & $\mathrm{T}$ \\
\hline
\end{tabular}




\begin{tabular}{|c|c|c|c|c|c|c|c|c|c|c|c|}
\hline Req. \# - ID & $\begin{array}{l}\text { Ref.in } \\
\text { Base } \\
\text { Std. }\end{array}$ & $\begin{array}{c}\text { Requirement } \\
\text { Summary }\end{array}$ & $\begin{array}{l}\text { L } \\
\text { e } \\
\text { v } \\
\text { e } \\
\text { l }\end{array}$ & $\begin{array}{l}\text { Assertion } \\
\text { ID }\end{array}$ & $\begin{array}{c}\text { Test } \\
\text { Assertion }\end{array}$ & $\begin{array}{l}\mathbf{N} \\
\mathbf{o} \\
\mathbf{t} \\
\mathrm{e} \\
\mathrm{S}\end{array}$ & $\begin{array}{c}\text { Imp. } \\
\text { Required }\end{array}$ & $\begin{array}{c}\text { Imp. } \\
\text { Support }\end{array}$ & $\begin{array}{l}\text { Supporte } \\
\text { d Range }\end{array}$ & $\begin{array}{c}\text { Test } \\
\text { Result }\end{array}$ & $\begin{array}{l}\mathbf{E} \\
\mathbf{n} \\
\mathbf{c} \\
\text {. }\end{array}$ \\
\hline \multicolumn{12}{|c|}{ Transaction-related Requirements } \\
\hline & & & & & ) & & & & & & \\
\hline $\begin{array}{l}\text { TX.11 - Tra } \\
\text { nsaction: } \\
\text { IDC } \\
\text { Sequential }\end{array}$ & 7.3.1 & $\begin{array}{l}\text { The value of the IDC shall be a } \\
\text { sequentially assigned positive integer } \\
\text { starting from zero and incremented by one } \\
\text { up to a maximum of } 99 \text {. IDC references are } \\
\text { stated in Type-1 Field } 1.003 \text { Transaction } \\
\text { content / CNT and shall be used to relate } \\
\text { information items in the CNT field of the } \\
\text { Type- } 1 \text { record to the other records in the } \\
\text { transaction. }\end{array}$ & 2 & $\begin{array}{c}\text { Transaction } \\
- \\
\text { IDCSequen } \\
\text { tialValues }\end{array}$ & $\begin{array}{l}\text { Complex } \\
\text { When arranged in numeric order, the set of all } \\
\text { IDC values in the transaction must begin with } 0 \text {, } \\
\text { increment by } 1 \text {, and the greatest value in the set } \\
\text { must be equal to or less than } 99 \\
\text { ) }\end{array}$ & t9 & $\begin{array}{c}\text { M- } \\
\text { Transaction }\end{array}$ & & & & $\mathrm{T}$ \\
\hline \multirow[t]{3}{*}{$\begin{array}{l}\text { TX.12 - Tra } \\
\text { nsaction: } \\
\text { IDC } \\
\text { Matching } \\
\text { Values }\end{array}$} & \multirow[t]{3}{*}{ 7.3.1 } & \multirow{3}{*}{$\begin{array}{l}\text { Two or more records may share a single } \\
\text { IDC solely to identify and link together } \\
\text { records that pertain to different } \\
\text { representations of the same biometric trait. } \\
\text { Two or more image records may share a } \\
\text { single IDC only when they are } \\
\text { enhancements of a single image; such } \\
\text { transformations shall have identical } \\
\text { dimensions. }\end{array}$} & 2 & $\begin{array}{c}\text { Transaction } \\
- \\
\text { MatchingID } \\
\text { CValues- } \\
\text { Comparable } \\
\text { BiometricT } \\
\text { ypes }\end{array}$ & Complex(See Note) & $\mathrm{t} 2$ & $\begin{array}{c}\text { M- } \\
\text { Transaction }\end{array}$ & & & & B \\
\hline & & & 2 & $\begin{array}{c}\text { Transaction } \\
- \\
\text { MatchingID } \\
\text { CSameImag } \\
\text { eDimension }\end{array}$ & $\begin{array}{l}\text { Complex } \\
\text { ForEach(Pair(A,B) of Records with matching IDC } \\
\text { fields }) \\
\{ \\
\{\text { A.006 }\} \text { EQ }\{\text { B. } 006\} \\
\text { AND }\{\text { E. }\{07\} \text { EQ }\{\text { B.007\} } \\
\{ \\
\}\end{array}$ & & $\begin{array}{c}\text { M- } \\
\text { Transaction }\end{array}$ & & & & B \\
\hline & & & 3 & $\begin{array}{c}\text { Transaction } \\
- \\
\text { IDCsFromS } \\
\text { ameImage }\end{array}$ & $\begin{array}{l}\text { ReturnResult } \\
\text { ( } \\
\text { Result } \\
\text { ( } \\
\text { Pass(Not feasible to test if the samples are from } \\
\text { the same image, only that the samples come from } \\
\text { the same type of biometric trait) } \\
\text { ) }\end{array}$ & & $\begin{array}{c}\text { M- } \\
\text { Transaction }\end{array}$ & & & & B \\
\hline $\begin{array}{l}\text { TX.13 - Fiel } \\
\text { d: } 1.003-\end{array}$ & $\begin{array}{l}\text { 8.1.3, } \\
\text { Table 22, }\end{array}$ & $\begin{array}{l}\text { IDC references are stated in Type- } 1 \text { Field } \\
1.003 \text { Transaction content / CNT and shall }\end{array}$ & 2 & $\begin{array}{l}\text { Transaction } \\
\text {-CNT- }\end{array}$ & Complex & & $\begin{array}{c}\text { M- } \\
\text { Transaction }\end{array}$ & & & & $\mathrm{T}$ \\
\hline
\end{tabular}




\begin{tabular}{|c|c|c|c|c|c|c|c|c|c|c|c|}
\hline Req. \# - ID & $\begin{array}{c}\text { Ref.in } \\
\text { Base } \\
\text { Std. }\end{array}$ & $\begin{array}{l}\text { Requirement } \\
\text { Summary }\end{array}$ & $\begin{array}{l}\text { L } \\
\text { e } \\
\text { v } \\
\text { e } \\
\text { l }\end{array}$ & $\begin{array}{l}\text { Assertion } \\
\text { ID }\end{array}$ & $\begin{array}{c}\text { Test } \\
\text { Assertion }\end{array}$ & $\begin{array}{l}\mathbf{N} \\
\mathbf{o} \\
\mathrm{t} \\
\mathrm{e} \\
\mathrm{S}\end{array}$ & $\begin{array}{c}\text { Imp. } \\
\text { Required }\end{array}$ & $\begin{array}{c}\text { Imp. } \\
\text { Support }\end{array}$ & $\begin{array}{l}\text { Supporte } \\
\text { d Range }\end{array}$ & $\begin{array}{c}\text { Test } \\
\text { Result }\end{array}$ & $\begin{array}{l}\mathbf{E} \\
\mathbf{n} \\
\mathbf{c} \\
\text {. }\end{array}$ \\
\hline \multicolumn{12}{|c|}{ Transaction-related Requirements } \\
\hline \multirow[t]{2}{*}{$\begin{array}{l}\text { Transaction } \\
\text { Content } \\
\text { Subfield } 2 \\
\text { IDC } \\
\text { Matches }\end{array}$} & 7.3.1 & $\begin{array}{l}\text { be used to relate information items in the } \\
\text { CNT field of the Type- } 1 \text { record to the other } \\
\text { records in the transaction. It also specifies } \\
\text { the order in which the remaining records } \\
\text { shall appear in the file. }\end{array}$ & & $\begin{array}{l}\text { REC-IDC- } \\
\text { Matches } \\
\text { Records }\end{array}$ & $\begin{array}{l}\text { ForEach (Record in Recs) } \\
\text { ( } \\
\text { Present(Subfield in } 1.003 \text { ST } \\
\text { AND } \\
( \\
\text { EQ(\{InfoI(1.003.REC) in Subfield }\}, \\
\text { RecType(Record)), } \\
\text { EQ( }\{\text { InfoI(1.003.IDC) in Subfield }\}, \\
\{\text { Record.002 }\}) \\
\text { ) } \\
\text { Note: The record types must appear in the same } \\
\text { order that they are listed in Fld }(1.003) \\
\text { ) }\end{array}$ & & & & & & \\
\hline & & & 2 & $\begin{array}{l}\text { NIEM- } \\
\text { Transaction } \\
\text { REC-CNT- } \\
\text { IDC- } \\
\text { Matches } \\
\text { Records }\end{array}$ & $\begin{array}{l}\text { Complex } \\
\text { ForEach (Record in Recs) } \\
\text { ( } \\
\text { Present(XElm(1.003.biom:ContentRecordSummar } \\
\text { y) ST } \\
\text { AND } \\
\text { ( } \\
\text { EQ(\{XElm(1.003.biomRecordCategoryCode) in } \\
\text { XElm(1.003.biom:ContentRecordSummary)\}, } \\
\text { RecType(Record)), } \\
\text { EQ(\{XElm(1.003.ImageReferenceIdentification) } \\
\text { in XElm(1.003.biom:ContentRecordSummary)\}, } \\
\{\text { Record.002\}) } \\
) \\
\text { ) } \\
\text { Note: The record types must appear in the same } \\
\text { order that they are listed in Fld(1.003) } \\
\text { ) }\end{array}$ & & $\begin{array}{c}\text { M- } \\
\text { Transaction }\end{array}$ & & & & $\mathrm{B}$ \\
\hline $\begin{array}{l}\text { TX.14 - Tra } \\
\text { nsaction: } \\
\text { SRN } \\
\text { Sequential }\end{array}$ & 7.3.2.1 & $\begin{array}{l}\text { The value of the } \\
\text { SRN shall be a sequentially assigned } \\
\text { positive integer starting from one and } \\
\text { incremented by } \\
\text { one, not to exceed } 255 \text {. }\end{array}$ & 2 & $\begin{array}{c}\text { Transaction } \\
\text {-SRN- } \\
\text { SequentialV } \\
\text { alues }\end{array}$ & $\begin{array}{l}\text { Complex } \\
\text { When arranged in numeric order, the set of all } \\
\text { SRN values in the transaction must begin with } 1 \text {, } \\
\text { increment by } 1 \text {, and the greatest value in the set } \\
\text { must be equal to or less than } 255 \\
\text { ) }\end{array}$ & t9 & $\begin{array}{c}\text { M- } \\
\text { Transaction }\end{array}$ & & & & B \\
\hline
\end{tabular}




\begin{tabular}{|c|c|c|c|c|c|c|c|c|c|c|c|}
\hline Req. \# - ID & $\begin{array}{l}\text { Ref.in } \\
\text { Base } \\
\text { Std. }\end{array}$ & $\begin{array}{l}\text { Requirement } \\
\text { Summary }\end{array}$ & $\begin{array}{l}\text { L } \\
\text { e } \\
\text { v } \\
\text { e } \\
\text { l }\end{array}$ & $\begin{array}{l}\text { Assertion } \\
\text { ID }\end{array}$ & $\begin{array}{c}\text { Test } \\
\text { Assertion }\end{array}$ & $\begin{array}{l}\mathbf{N} \\
\mathbf{o} \\
\mathbf{t} \\
\mathrm{e} \\
\mathrm{S}\end{array}$ & $\begin{array}{c}\text { Imp. } \\
\text { Required }\end{array}$ & $\begin{array}{c}\text { Imp. } \\
\text { Support }\end{array}$ & $\begin{array}{l}\text { Supporte } \\
\text { d Range }\end{array}$ & $\begin{array}{c}\text { Test } \\
\text { Result }\end{array}$ & $\begin{array}{l}\mathbf{E} \\
\mathbf{n} \\
\mathbf{c}\end{array}$ \\
\hline \multicolumn{12}{|c|}{ Transaction-related Requirements } \\
\hline $\begin{array}{l}\text { TX.15 - Tra } \\
\text { nsaction: } \\
\text { ACN } \\
\text { Sequential }\end{array}$ & $\begin{array}{l}7.3 \\
7.3 .3 .1\end{array}$ & $\begin{array}{l}\text { The value of the ACN shall be a } \\
\text { sequentially assigned a positive integer } \\
\text { starting from one and incremented by one, } \\
\text { not to exceed } 255 \text {. }\end{array}$ & 2 & $\begin{array}{l}\text { Transaction } \\
\text {-ACN- } \\
\text { SequentialV } \\
\quad \text { alues }\end{array}$ & $\begin{array}{l}\text { Complex } \\
\text { When arranged in numeric order, the set of all } \\
\text { ACN values in the transaction must begin with } 1 \text {, } \\
\text { increment by } 1 \text {, and the greatest value in the set } \\
\text { must be equal to or less than } 255 \\
\text { ) }\end{array}$ & t9 & $\begin{array}{c}\text { M- } \\
\text { Transaction }\end{array}$ & & & & B \\
\hline \multirow[t]{2}{*}{$\begin{array}{l}\text { TX.16 - Tra } \\
\text { nsaction: } \\
\text { T10 } \\
\text { Matching }\end{array}$} & $\begin{array}{l}7.3 \\
7.3 .4\end{array}$ & $\begin{array}{l}\text { There may be several Type- } 10 \text { images of a } \\
\text { particular part of the body. For instance, a } \\
\text { photograph of a tattoo may cover the entire } \\
\text { tattoo. Another may be a zoom-in shot of a } \\
\text { portion of the tattoo. In order to link these } \\
\text { two images, the same index number is } \\
\text { assigned to Field } 10.039 \text { : Type- } 10 \\
\text { reference number / T10, which is new to } \\
\text { this version of the standard. Note that these } \\
\text { images would have different IDC values. }\end{array}$ & 2 & $\begin{array}{l}\text { Transaction } \\
\text {-SameT10- } \\
\text { DiffIDC }\end{array}$ & $\begin{array}{l}\text { Complex } \\
\text { ForEach(Pair (A,B) of Records ST } \\
\text { RecType(Records) EQ 10) } \\
\{ \\
\text { IF }\{\text { A.039\} EQ }\{\text { B.039\} } \\
\text { THEN } \\
\{\text { A.002\} NEQ }\{\text { B. } 002\} \\
\} \\
\{\end{array}$ & & $\begin{array}{c}\text { M- } \\
\text { Transaction }\end{array}$ & & & & $\mathrm{T}$ \\
\hline & & & 2 & $\begin{array}{l}\text { NIEM- } \\
\text { Transaction } \\
\text {-SameT10- } \\
\text { DiffIDC }\end{array}$ & $\begin{array}{l}\text { Complex } \\
\text { ForEach(Pair (A,B) of } \\
\text { XElm(itl:PackageFacialAndSMTImageRecord) } \\
\text { IF \{XElm(nc:IdentificationID) in } \\
\text { XElm(biom:PhysicalFeatureReferenceIdentificati } \\
\text { on) in A\} EQ \{ XElm(nc:IdentificationID) in } \\
\text { XElm(biom:PhysicalFeatureReferenceIdentificati } \\
\text { on) in B }\} \\
\text { THEN } \\
\{\text { XElm(nc:IdentificationID) in } \\
\text { XElm(biom:ImageReferenceIdentification) in A\} } \\
\text { NEQ \{ XElm(nc:IdentificationID) in } \\
\text { XElm(biom:ImageReferenceIdentification) in B }\} \\
\} \\
\text { ) }\end{array}$ & & $\begin{array}{c}\text { M- } \\
\text { Transaction }\end{array}$ & & & & $\mathrm{X}$ \\
\hline $\begin{array}{l}\text { TX.17 - Tra } \\
\text { nsaction: } \\
\text { Schema } \\
\text { Validation }\end{array}$ & $\begin{array}{c}\text { C.2, C. } 4 \text {, } \\
\text { C.5.1 }\end{array}$ & $\begin{array}{l}\text { The ordering of elements is strict. The } \\
\text { schemas referenced by this annex define } \\
\text { the order and nesting structure of elements. } \\
\text { The schemas also provide a W3C } \\
\text { representation of the order and hierarchical }\end{array}$ & 2 & $\begin{array}{l}\text { NIEM- } \\
\text { Schema } \\
\text { Validation }\end{array}$ & $\begin{array}{l}\text { Complex } \\
\text { Perform and report Schema validation. Provide } \\
\text { warning that the schema does not strictly enforce } \\
\text { the standard, so the conformance of a }\end{array}$ & $\mathrm{t} 10$ & $\begin{array}{c}\text { M- } \\
\text { Transaction }\end{array}$ & & & & $\mathrm{X}$ \\
\hline
\end{tabular}




\begin{tabular}{|c|c|c|c|c|c|c|c|c|c|c|c|}
\hline Req. \# - ID & $\begin{array}{c}\text { Ref.in } \\
\text { Base } \\
\text { Std. }\end{array}$ & $\begin{array}{l}\text { Requirement } \\
\text { Summary }\end{array}$ & $\begin{array}{l}\text { L } \\
\text { e } \\
\text { v } \\
\text { e } \\
\text { l }\end{array}$ & $\begin{array}{l}\text { Assertion } \\
\text { ID }\end{array}$ & $\begin{array}{c}\text { Test } \\
\text { Assertion }\end{array}$ & $\begin{array}{l}\mathbf{N} \\
\mathbf{o} \\
\mathbf{t} \\
\mathrm{e} \\
\mathbf{S}\end{array}$ & $\begin{array}{c}\text { Imp. } \\
\text { Required }\end{array}$ & $\begin{array}{c}\text { Imp. } \\
\text { Support }\end{array}$ & $\begin{array}{l}\text { Supporte } \\
\text { d Range }\end{array}$ & $\begin{array}{c}\text { Test } \\
\text { Result }\end{array}$ & \\
\hline \multicolumn{12}{|c|}{ Transaction-related Requirements } \\
\hline & & $\begin{array}{l}\text { structure of the XML content. } \\
\text { The XML schema referenced for this } \\
\text { encoding define the structure and order of } \\
\text { the elements in the information exchange } \\
\text { package. To the extent possible, the } \\
\text { schema define data types and constraints } \\
\text { that enforce the allowable content rules of } \\
\text { the base standard. } \\
\text { Nevertheless, the XML schema may not } \\
\text { strictly enforce the allowable content. The } \\
\text { base standard defines allowable content, } \\
\text { and its requirements shall be met by } \\
\text { implementers regardless of encoding } \\
\text { method. } \\
\text { All of this standard's required elements } \\
\text { shall be present in a conforming instance } \\
\text { document even if the schema referenced by } \\
\text { this annex do not strictly enforce the } \\
\text { requirement. } \\
\text { The base standard defines allowable } \\
\text { content, and its requirements shall be met } \\
\text { by implementers regardless of encoding } \\
\text { method. }\end{array}$ & & & $\begin{array}{l}\text { transaction cannot be claimed from the result of } \\
\text { schema validation. However, the Schema } \\
\text { validation does indicate that structural } \\
\text { requirements have been met, including } \\
\text { appropriate ordering of the elements. } \\
\text { ) }\end{array}$ & & & & & & \\
\hline $\begin{array}{l}\text { TX.18 - Tra } \\
\text { nsaction } \\
\text { Valid } \\
\text { Encoding }\end{array}$ & C. 4.1 & $\begin{array}{l}\text { Each XML information element, tags and } \\
\text { data content, shall be represented by a } \\
\text { character set that is a subset of Unicode } \\
\text { and that is allowable by W3C XML. } \\
\text { Characters shall be transmitted using a } \\
\text { Unicode encoding. }\end{array}$ & 1 & $\begin{array}{c}\text { NIEM- } \\
\text { XML } \\
\text { Encoding }\end{array}$ & $\begin{array}{l}\text { MO } \\
( \\
\{\text { Firstln(EImsInTx)\}, } \\
\text { Set-Str( [UTF-8, UTF-16, UTF-32]) } \\
\text { ) }\end{array}$ & & $\begin{array}{c}\text { M- } \\
\text { Transaction }\end{array}$ & & & & $\mathrm{X}$ \\
\hline $\begin{array}{l}\text { TX.19 - Tra } \\
\text { nsaction } \\
\text { Encoding } \\
\text { Declaration }\end{array}$ & C. 4.1 & $\begin{array}{l}\text { XML packages shall include an XML } \\
\text { declaration that specifies the encoding. }\end{array}$ & 1 & $\begin{array}{c}\text { NIEM- } \\
\text { XML } \\
\text { Declaration }\end{array}$ & $\begin{array}{l}\text { EQ } \\
\text { (ElmName(First } \ln (E \operatorname{lm} \ln T x)) \\
\text { Str(?xml) } \\
\text { ) }\end{array}$ & & $\begin{array}{c}\text { M- } \\
\text { Transaction }\end{array}$ & & & & $\mathrm{X}$ \\
\hline
\end{tabular}




\begin{tabular}{|c|c|c|c|c|c|c|c|c|c|c|}
\hline Req. \# - ID & $\begin{array}{l}\text { Ref.in } \\
\text { Base } \\
\text { Std. }\end{array}$ & $\begin{array}{c}\text { Requirement } \\
\text { Summary }\end{array}$ & $\begin{array}{l}\mathbf{L} \\
\mathbf{e} \\
\mathbf{v} \\
\mathrm{e} \\
\mathbf{l}\end{array}$ & $\begin{array}{l}\text { Assertion } \\
\text { ID }\end{array}$ & $\begin{array}{c}\text { Test } \\
\text { Assertion }\end{array}$ & $\begin{array}{l}\mathbf{N} \\
\mathbf{o} \\
\mathbf{t} \\
\mathbf{e} \\
\mathbf{S}\end{array}$ & $\begin{array}{c}\text { Imp. } \\
\text { Required }\end{array}$ & $\begin{array}{c}\text { Imp. } \\
\text { Support }\end{array}$ & $\begin{array}{l}\text { Supporte } \\
\text { d Range }\end{array}$ & $\begin{array}{c}\text { Test } \\
\text { Result }\end{array}$ \\
\hline \multicolumn{11}{|c|}{ Transaction-related Requirements } \\
\hline XML & & $\begin{array}{l}\text { an end tag of format }\langle/ \text { Name }>\text {. For all } \\
\text { logical records - including Types } 4,7 \text {, and } \\
8 \text { that do not have field tags in the } \\
\text { Traditional encoding -- data elements are } \\
\text { tagged according to XML rules. The } \\
\text { format for each element shall consist of a } \\
\text { start tag enclosed in angle brackets } \\
\text { followed by data followed by an end tag. }\end{array}$ & & & 1 & & & & & \\
\hline
\end{tabular}

Table C.2 - Assertions for Record Type 1: Transaction information record

\begin{tabular}{|c|c|c|c|c|c|c|c|c|c|c|c|}
\hline Req. \# - ID & $\begin{array}{l}\text { Ref. in } \\
\text { Base } \\
\text { Std. }\end{array}$ & $\begin{array}{l}\text { Requirement } \\
\text { Summary }\end{array}$ & $\begin{array}{l}\text { L } \\
\text { e } \\
\mathrm{v} \\
\mathrm{e} \\
\mathrm{l}\end{array}$ & $\begin{array}{l}\text { Assertion } \\
\text { ID }\end{array}$ & $\begin{array}{c}\text { Test } \\
\text { Assertion }\end{array}$ & $\begin{array}{l}\mathbf{N} \\
\mathbf{o} \\
\mathbf{t} \\
\mathbf{e} \\
\mathbf{S}\end{array}$ & $\begin{array}{c}\text { Imp. } \\
\text { Required }\end{array}$ & $\begin{array}{c}\text { Imp. } \\
\text { Support }\end{array}$ & $\begin{array}{l}\text { Supporte } \\
\text { d Range }\end{array}$ & $\begin{array}{l}\text { Test } \\
\text { Result }\end{array}$ & $\begin{array}{l}\mathbf{E} \\
\mathbf{n} \\
\mathbf{c} \\
\text {. }\end{array}$ \\
\hline \multicolumn{12}{|c|}{ Record Type-1: Transaction information record } \\
\hline \multirow[t]{2}{*}{$\begin{array}{l}\text { RT1.1 - Rec } \\
\text { ord: } \\
\text { RecordHead } \\
\text { erFirst }\end{array}$} & 7.1 & $\begin{array}{l}\text { The record header appears as the first field } \\
\text { (xx.001) in each Record Type. } \\
\text { The record header exists only in } \\
\text { Traditional Encoding. }\end{array}$ & 1 & $\begin{array}{l}\text { Type1- } \\
\text { Field001Firs } \\
\mathrm{t}\end{array}$ & $\begin{array}{l}\text { EQ } \\
\text { FieldNum(FirstIn(FldsInRec(Rec(1)))), } \\
\text { Int(1) }\end{array}$ & & $M-\operatorname{Rec}(1)$ & & & & $\mathrm{T}$ \\
\hline & & & 1 & $\begin{array}{c}\text { NIEM- } \\
\text { Type1- } \\
\text { Field001Firs } \\
\mathrm{t}\end{array}$ & $\begin{array}{l}\text { EQ } \\
\text { ElmName(FirstIn(ElmsIn(itl:PackageInformation } \\
\text { Record))), } \\
\text { Str(biom:RecordCategoryCode) } \\
)\end{array}$ & & $M-\operatorname{Rec}(1)$ & & & & $\mathrm{X}$ \\
\hline $\begin{array}{l}\text { RT1.2 - Rec } \\
\text { ord: Type1- } \\
\text { 7-bitASCII }\end{array}$ & $\begin{array}{c}8.1 \\
5.6 \\
\text { Table } 93\end{array}$ & $\begin{array}{l}\text { Note that since the alternate character } \\
\text { encoding is specified in this record, there } \\
\text { must be specified characters agreed upon } \\
\text { in order to read this Record Type, } \\
\text { particularly with Traditional encoding, and } \\
\text { the characters that can be represented by } \\
\text { the } 7 \text {-bit ASCII code are those characters } \\
\text { (see Table } 93 \text { for these characters). }\end{array}$ & 1 & $\begin{array}{l}\text { Type1- } \\
\text { ASCII }\end{array}$ & $\begin{array}{l}\text { ReturnResult } \\
\text { Result } \\
\text { ( } \\
\text { Pass(Character Type assertions are performed on } \\
\text { all data in Record Type-1. These assertions are } \\
\text { more restrictive because they test for character } \\
\text { ranges that are a subset of 7-bit ASCII. Refer to } \\
\text { the individual tests on data to determine the }\end{array}$ & & $M-\operatorname{Rec}(1)$ & & & & $\mathrm{T}$ \\
\hline
\end{tabular}




\begin{tabular}{|c|c|c|c|c|c|c|c|c|c|c|c|}
\hline Req. \# - ID & $\begin{array}{l}\text { Ref. in } \\
\text { Base } \\
\text { Std. }\end{array}$ & $\begin{array}{l}\text { Requirement } \\
\text { Summary }\end{array}$ & $\begin{array}{l}\text { L } \\
\text { e } \\
\text { v } \\
\text { e } \\
\text { l }\end{array}$ & $\begin{array}{l}\text { Assertion } \\
\text { ID }\end{array}$ & $\begin{array}{c}\text { Test } \\
\text { Assertion }\end{array}$ & $\begin{array}{l}\mathbf{N} \\
\mathbf{o} \\
\mathbf{t} \\
\mathbf{e} \\
\mathbf{S}\end{array}$ & $\begin{array}{l}\text { Imp. } \\
\text { Required }\end{array}$ & $\begin{array}{l}\text { Imp. } \\
\text { Support }\end{array}$ & $\begin{array}{l}\text { Supporte } \\
\text { d Range }\end{array}$ & $\begin{array}{c}\text { Test } \\
\text { Result }\end{array}$ & $\begin{array}{l}\mathbf{E} \\
\mathbf{n} \\
\mathbf{c} \\
\text {. }\end{array}$ \\
\hline \multicolumn{12}{|c|}{ Record Type-1: Transaction information record } \\
\hline & & $\begin{array}{l}\text { Record Type- } 1 \text { shall always be recorded in } \\
\text { all encodings using the characters that } \\
\text { can be represented by the } 7 \text {-bit } \\
\text { American National Standard Code for } \\
\text { Information Interchange (ASCII) found in } \\
\text { table } 93 \text { with the exception of the reserved } \\
\text { values. }\end{array}$ & & & $\begin{array}{l}\text { results.) } \\
\text { ) }\end{array}$ & & & & & & \\
\hline \multirow[t]{2}{*}{$\begin{array}{l}\text { RT1.3 - Rec } \\
\text { ord: Type1- } \\
\text { Reserved }\end{array}$} & Table 22 & $\begin{array}{l}\text { Table } 22 \text { specifies which fields are } \\
\text { permitted to be present in a Type-1 Record. } \\
\text { All others are reserved for future use. }\end{array}$ & 1 & $\begin{array}{l}\text { Type1- } \\
\text { ReservedFie } \\
\text { lds }\end{array}$ & $\begin{array}{l}\text { Not } \\
\text { ( AnyPresent(Set-Fld([1.019 to 1.999]) } \\
\text { ) }\end{array}$ & & M-Rec(1) & & & & $\mathrm{T}$ \\
\hline & & & 1 & $\begin{array}{l}\text { NIEM- } \\
\text { Type1- } \\
\text { ReservedFie } \\
\text { lds }\end{array}$ & $\begin{array}{l}\text { ReturnResult } \\
\text { ( } \\
\text { Result } \\
\text { ( } \\
\text { Pass(Reserved Fields are not defined for NIEM- } \\
\text { XML. The presence of any undefined elements } \\
\text { will fail Schema validation) } \\
\text { ) }\end{array}$ & $\mathrm{t} 10$ & $\mathrm{M}-\operatorname{Rec}(1)$ & & & & $\mathrm{X}$ \\
\hline \multirow[t]{4}{*}{$\begin{array}{l}\text { RT1.4 - Rec } \\
\text { ord: Type1- } \\
\text { FieldOccurr } \\
\quad \text { ence }\end{array}$} & \multirow[t]{4}{*}{$\begin{array}{l}\text { Table 22, } \\
\text { Annex G }\end{array}$} & \multirow[t]{4}{*}{$\begin{array}{l}\text { Table } 22 \text { specifies the Field Occurrence for } \\
\text { each field. } \\
\text { Annex G specifies the cardinality for the } \\
\text { XML elements. }\end{array}$} & 1 & $\begin{array}{l}\text { Type1- } \\
1.001- \\
\text { Occurrences }\end{array}$ & $\begin{array}{l}\text { EQ } \\
\text { Count(FldsInRec(Rec(1), } \operatorname{Int}(1))) \text {, } \\
\text { Int(1) }\end{array}$ & & M-Rec(1) & & & & $\mathrm{T}$ \\
\hline & & & 1 & $\begin{array}{l}\text { Type1- } \\
1.002- \\
\text { Occurrences }\end{array}$ & $\begin{array}{l}\text { EQ } \\
( \\
\text { Count(FldsInRec(Rec(1), } \operatorname{Int}(2))) \text {, } \\
\text { Int(1) }\end{array}$ & & M-Rec(1) & & & & $\mathrm{T}$ \\
\hline & & & 1 & $\begin{array}{l}\text { Type1- } \\
1.003- \\
\text { Occurrences }\end{array}$ & $\begin{array}{l}\text { EQ } \\
\text { Count(FldsInRec(Rec(1), } \operatorname{Int}(3))) \text {, } \\
\text { Int(1) }\end{array}$ & & $\mathrm{M}-\operatorname{Rec}(1)$ & & & & $\mathrm{T}$ \\
\hline & & & 1 & $\begin{array}{c}\text { Type1- } \\
1.004- \\
\text { Occurrences }\end{array}$ & $\begin{array}{l}\text { EQ } \\
( \\
\text { Count(FIdsInRec(Rec(1), } \operatorname{Int}(4))) \text {, } \\
\text { Int(1) }\end{array}$ & & M-Rec(1) & & & & $\mathrm{T}$ \\
\hline
\end{tabular}




\begin{tabular}{|c|c|c|c|c|c|c|c|c|c|c|c|}
\hline Req. \# - ID & $\begin{array}{l}\text { Ref. in } \\
\text { Base } \\
\text { Std. }\end{array}$ & $\begin{array}{c}\text { Requirement } \\
\text { Summary }\end{array}$ & $\begin{array}{l}\mathbf{L} \\
\mathbf{e} \\
\mathbf{v} \\
\mathrm{e} \\
\mathbf{l}\end{array}$ & $\begin{array}{l}\text { Assertion } \\
\text { ID }\end{array}$ & $\begin{array}{c}\text { Test } \\
\text { Assertion }\end{array}$ & $\begin{array}{l}\mathbf{N} \\
\mathbf{0} \\
\mathbf{t} \\
\mathbf{e} \\
\mathbf{S}\end{array}$ & $\begin{array}{c}\text { Imp. } \\
\text { Required }\end{array}$ & $\begin{array}{c}\text { Imp. } \\
\text { Support }\end{array}$ & $\begin{array}{l}\text { Supporte } \\
\text { d Range }\end{array}$ & $\begin{array}{c}\text { Test } \\
\text { Result }\end{array}$ & $\begin{array}{l}\mathbf{E} \\
\mathbf{n} \\
\mathbf{c} \\
\text {. }\end{array}$ \\
\hline \multicolumn{12}{|c|}{ Record Type-1: Transaction information record } \\
\hline & & & 1 & $\begin{array}{l}\text { Type1- } \\
1.005- \\
\text { Occurrences }\end{array}$ & $\begin{array}{l}\text { EQ } \\
( \\
\operatorname{Count}(\operatorname{Flds} \operatorname{In} \operatorname{Rec}(\operatorname{Rec}(1), \operatorname{Int}(5))) \text {, } \\
)\end{array}$ & & $\mathrm{M}-\operatorname{Rec}(1)$ & & & & $\mathrm{T}$ \\
\hline & & & 1 & $\begin{array}{c}\text { Type1- } \\
\text { 1.006- } \\
\text { Occurrences }\end{array}$ & $\begin{array}{l}\text { MO } \\
( \\
\text { Count(FldsInRec(Rec(1), Int(6))), } \\
\text { Set-Int }([0,1])\end{array}$ & & $\mathrm{M}-\operatorname{Rec}(1)$ & & & & $\mathrm{T}$ \\
\hline & & & 1 & $\begin{array}{l}\text { Type1- } \\
1.007- \\
\text { Occurrences }\end{array}$ & $\begin{array}{l}\text { EQ } \\
\text { Count(FldsInRec(Rec(1), Int(7))), } \\
\operatorname{Int}(1)\end{array}$ & & M-Rec(1) & & & & $\mathrm{T}$ \\
\hline & & & 1 & $\begin{array}{c}\text { Type1- } \\
1.008- \\
\text { Occurrences }\end{array}$ & $\begin{array}{l}\text { EQ } \\
\text { Count(FldsInRec(Rec(1), } \operatorname{Int}(8))) \text {, } \\
\operatorname{Int}(1)\end{array}$ & & M-Rec(1) & & & & $\mathrm{T}$ \\
\hline & & & 1 & $\begin{array}{c}\text { Type1- } \\
1.009- \\
\text { Occurrences }\end{array}$ & $\begin{array}{l}\text { EQ } \\
(\text { Count(FldsInRec(Rec(1), Int(9))), } \\
\operatorname{Int}(1)\end{array}$ & & M-Rec(1) & & & & $\mathrm{T}$ \\
\hline & & & 1 & $\begin{array}{c}\text { Type1- } \\
1.010- \\
\text { Occurrences }\end{array}$ & $\begin{array}{l}\text { MO } \\
(\text { Count(FldsInRec(Rec(1), Int(10))), } \\
\text { Set-Int }([0,1])\end{array}$ & & $\mathrm{M}-\operatorname{Rec}(1)$ & & & & $\mathrm{T}$ \\
\hline & & & 1 & $\begin{array}{l}\text { Type1- } \\
1.011- \\
\text { Occurrences }\end{array}$ & $\begin{array}{l}\text { EQ } \\
(\text { Count(FldsInRec(Rec(1), Int(11))), } \\
\operatorname{Int}(1)\end{array}$ & & $\mathrm{M}-\operatorname{Rec}(1)$ & & & & $\mathrm{T}$ \\
\hline & & & 1 & $\begin{array}{c}\text { Type1- } \\
1.012- \\
\text { Occurrences }\end{array}$ & $\begin{array}{l}\text { EQ } \\
( \\
\text { Count(FldsInRec(Rec(1), } \operatorname{Int}(12))) \text {, } \\
\operatorname{Int}(1)\end{array}$ & & $\mathrm{M}-\operatorname{Rec}(1)$ & & & & $\mathrm{T}$ \\
\hline & & & 1 & $\begin{array}{c}\text { Type1- } \\
1.013-\end{array}$ & MO & & M-Rec(1) & & & & $\mathrm{T}$ \\
\hline
\end{tabular}




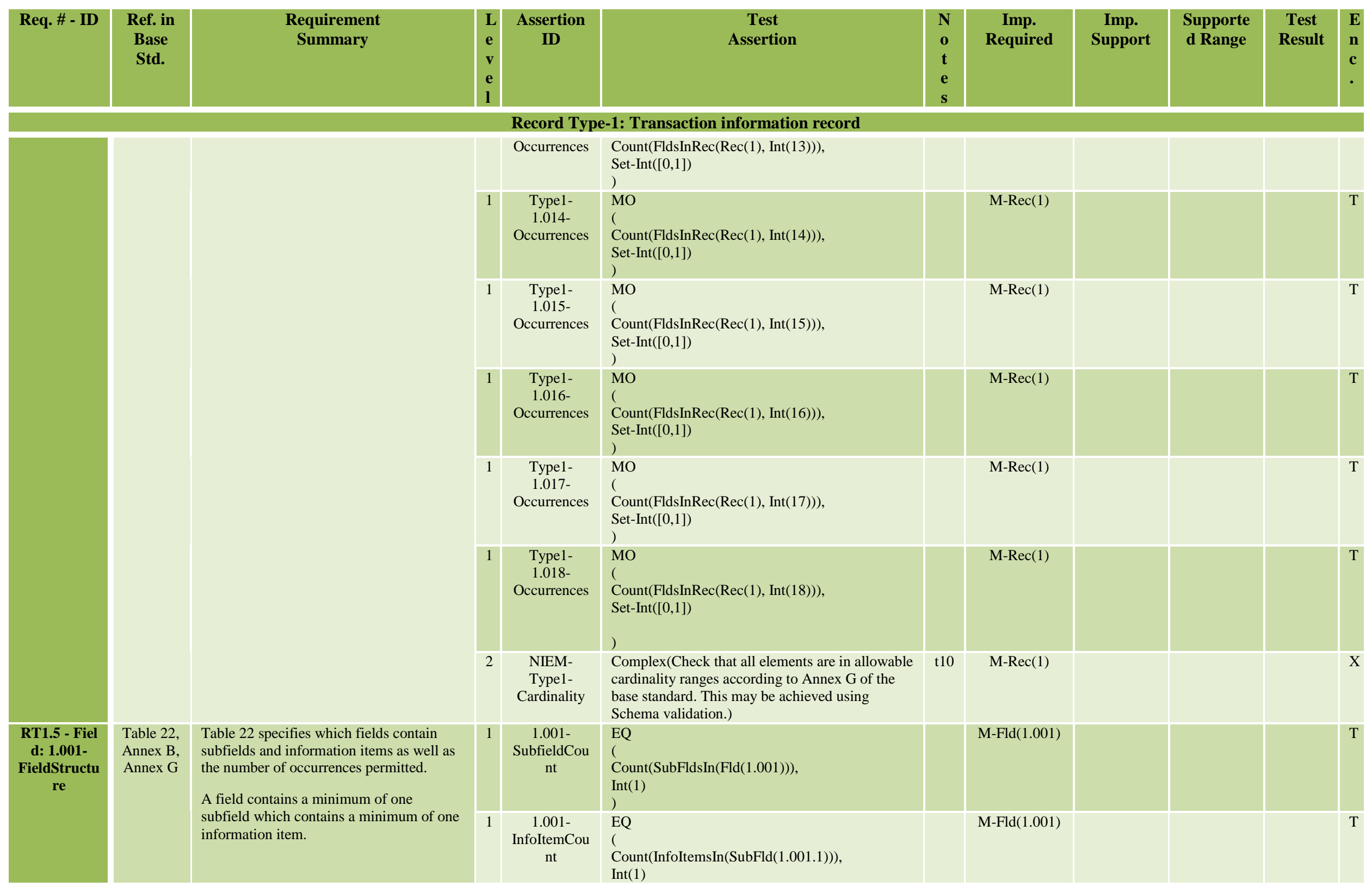




\begin{tabular}{|c|c|c|c|c|c|c|c|c|c|c|c|}
\hline Req. \# - ID & $\begin{array}{l}\text { Ref. in } \\
\text { Base } \\
\text { Std. }\end{array}$ & $\begin{array}{l}\text { Requirement } \\
\text { Summary }\end{array}$ & $\begin{array}{l}\text { L } \\
\text { e } \\
\text { v } \\
\text { e } \\
\text { l }\end{array}$ & $\begin{array}{l}\text { Assertion } \\
\text { ID }\end{array}$ & $\begin{array}{c}\text { Test } \\
\text { Assertion }\end{array}$ & $\begin{array}{l}\mathbf{N} \\
\mathbf{o} \\
\mathbf{t} \\
\mathbf{e} \\
\mathbf{S}\end{array}$ & $\begin{array}{c}\text { Imp. } \\
\text { Required }\end{array}$ & $\begin{array}{c}\text { Imp. } \\
\text { Support }\end{array}$ & $\begin{array}{l}\text { Supporte } \\
\text { d Range }\end{array}$ & $\begin{array}{c}\text { Test } \\
\text { Result }\end{array}$ & $\begin{array}{l}\mathbf{E} \\
\mathbf{n} \\
\mathbf{c} \\
\text {. }\end{array}$ \\
\hline \multicolumn{12}{|c|}{ Record Type-1: Transaction information record } \\
\hline & & & & & ) & & & & & & \\
\hline \multirow[t]{3}{*}{$\begin{array}{l}\text { RT1.6 - Fiel } \\
\text { d: } 1.001- \\
\text { Value }\end{array}$} & \multirow[t]{3}{*}{$\begin{array}{l}8.1 .1 \\
\text { Table } 22, \\
7.1 \\
\text { C. } 10.1\end{array}$} & \multirow{3}{*}{$\begin{array}{l}\text { Field } 1.001 \text { Record header. In Traditional } \\
\text { encoding, this field contains the record } \\
\text { length in bytes (including all information } \\
\text { separators). The value is unrestricted in } \\
\text { Traditional Encoding, but must be at least } \\
2 \text { to accommodate the size of required } \\
\text { fields. } \\
\text { The XML name for the Type-1 record is } \\
\text { <itl:PackageInformationRecord>, and its } \\
\text { <biom:RecordCategoryCode> element } \\
\text { shall have a value of "1". }\end{array}$} & 1 & 1.001-Value & $\begin{array}{l}\text { GTE } \\
(\text { Fld }(1.001)\}, \\
\operatorname{Int}(2)\end{array}$ & & M-Fld(1.001) & & & & $\mathrm{T}$ \\
\hline & & & 2 & $\begin{array}{l}1.001- \\
\text { Value- } \\
\text { Dependent }\end{array}$ & $\begin{array}{l}\text { EQ } \\
( \\
\{\text { Fld }(1.001)\}, \\
\text { Count }(\operatorname{Bytes}(\operatorname{Rec}(1)))\end{array}$ & & M-Fld(1.001) & & & & $\mathrm{T}$ \\
\hline & & & 1 & $\begin{array}{l}\text { NIEM- } \\
\text { 1.001-Value }\end{array}$ & $\begin{array}{l}\text { EQ } \\
( \\
\{\text { XElm(1.001.biom:RecordCategoryCode })\}, \\
\operatorname{Str}(1) \\
)\end{array}$ & & M-Fld(1.001) & & & & $\mathrm{X}$ \\
\hline \multirow[t]{2}{*}{$\begin{array}{l}\text { RT1.7 - Fiel } \\
\text { d: } 1.001- \\
\text { CharType }\end{array}$} & \multirow[t]{2}{*}{$\begin{array}{c}8.1 \\
\text { Table 22, } \\
8\end{array}$} & \multirow{2}{*}{$\begin{array}{l}\text { Section } 8.1 \text { and Table } 22 \text { specify the } \\
\text { Character Type for each field. } \\
\text { Numeric values shall not contain leading } \\
\text { zeros unless indicated by the standard text. } \\
\text { Leading zeros are allowed for } 1.002,1.011 \text {, } \\
1.012,99.100 \text {, and } 99.101 . \text { Any dates may } \\
\text { also contain leading zeros. }\end{array}$} & 1 & $\begin{array}{c}\text { 1.001- } \\
\text { CharType }\end{array}$ & $\begin{array}{l}\text { SubSet } \\
(\text { Chars }(\{\operatorname{Fld}(1.001)\}) \\
\text { CharNum } \\
\text { ) }\end{array}$ & & M-Fld(1.001) & & & & B \\
\hline & & & 1 & $\begin{array}{l}\text { 1.001- } \\
\text { NoLeadingZ } \\
\quad \text { eros }\end{array}$ & $\begin{array}{l}\text { NOT } \\
( \\
\text { RegEx } \\
( \\
\{\text { Fld }(1.001)\} \\
\text { LeadingZeroNum } \\
) \\
)\end{array}$ & & M-Fld(1.001) & & & & B \\
\hline \multirow[t]{2}{*}{$\begin{array}{l}\text { RT1.8 - Fiel } \\
\text { d: } 1.001- \\
\text { CharCount }\end{array}$} & \multirow[t]{2}{*}{$\begin{array}{c}\text { Table } 22, \\
7.1\end{array}$} & \multirow[t]{2}{*}{$\begin{array}{l}\text { Table } 22 \text { specifies the character count for } \\
\text { each field. } \\
\text {... a minimum of } 2 \text { characters for the } \\
\text { logical record length in Record Type- } 1 \ldots\end{array}$} & 1 & $\begin{array}{c}1.001- \\
\text { CharCount }\end{array}$ & $\begin{array}{l}\text { GTE } \\
( \\
\operatorname{Count}(\operatorname{Chars}(\{\operatorname{Fld}(1.001)\}), \\
\operatorname{Int}(2)\end{array}$ & & M-Fld(1.001) & & & & $\mathrm{T}$ \\
\hline & & & 1 & $\begin{array}{l}\text { NIEM- } \\
1.001- \\
\text { CharCount }\end{array}$ & $\begin{array}{l}\text { EQ } \\
( \\
\text { Count }(\operatorname{Chars}(\{\operatorname{Fld}(1.001)\}) \\
\text { Int(1) } \\
)\end{array}$ & & M-Fld(1.001) & & & & $\mathrm{X}$ \\
\hline $\begin{array}{l}\text { RT1.9 - Fiel } \\
\text { d: } 1.002-\end{array}$ & $\begin{array}{l}\text { Table 22, } \\
\text { Annex B, }\end{array}$ & $\begin{array}{l}\text { Table } 22 \text { specifies which fields contain } \\
\text { subfields and information items as well as }\end{array}$ & 1 & $\begin{array}{l}\text { 1.002-VER- } \\
\text { SubfieldCou }\end{array}$ & EQ & & M-Fld(1.002) & & & & $\mathrm{T}$ \\
\hline
\end{tabular}




\begin{tabular}{|c|c|c|c|c|c|c|c|c|c|c|c|}
\hline Req. \# - ID & $\begin{array}{l}\text { Ref. in } \\
\text { Base } \\
\text { Std. }\end{array}$ & $\begin{array}{l}\text { Requirement } \\
\text { Summary }\end{array}$ & $\begin{array}{l}\text { L } \\
\text { e } \\
\text { v } \\
\text { e } \\
\text { l }\end{array}$ & $\begin{array}{l}\text { Assertion } \\
\text { ID }\end{array}$ & $\begin{array}{c}\text { Test } \\
\text { Assertion }\end{array}$ & $\begin{array}{l}\mathbf{N} \\
\mathbf{o} \\
\mathbf{t} \\
\mathrm{e} \\
\mathbf{S}\end{array}$ & $\begin{array}{l}\text { Imp. } \\
\text { Required }\end{array}$ & $\begin{array}{l}\text { Imp. } \\
\text { Support }\end{array}$ & $\begin{array}{l}\text { Supporte } \\
\text { d Range }\end{array}$ & $\begin{array}{c}\text { Test } \\
\text { Result }\end{array}$ & $\begin{array}{l}\mathbf{E} \\
\mathbf{n} \\
\mathbf{c} \\
.\end{array}$ \\
\hline \multicolumn{12}{|c|}{ Record Type-1: Transaction information record } \\
\hline \multirow[t]{2}{*}{$\begin{array}{l}\text { VER- } \\
\text { FieldStructu } \\
\text { re }\end{array}$} & \multirow[t]{2}{*}{ Annex G } & \multirow{2}{*}{$\begin{array}{l}\text { the number of occurrences permitted. } \\
\text { A field contains a minimum of one } \\
\text { subfield which contains a minimum of one } \\
\text { information item. }\end{array}$} & & $\mathrm{nt}$ & $\begin{array}{l}\text { Count(SubFldsIn(Fld(1.002))), } \\
\text { Int(1) }\end{array}$ & & & & & & \\
\hline & & & 1 & $\begin{array}{l}\text { 1.002-VER- } \\
\text { InfoItemCou } \\
\mathrm{nt}\end{array}$ & $\begin{array}{l}\text { EQ } \\
\text { Count(InfoItemsIn(SubFld(1.002.1))), } \\
\text { Int(1) }\end{array}$ & & M-Fld(1.002) & & & & $\mathrm{T}$ \\
\hline \multirow[t]{2}{*}{$\begin{array}{l}\text { RT1.10 - Fie } \\
\text { Id: } 1.002- \\
\text { VER-Value }\end{array}$} & \multirow[t]{2}{*}{8.1 .2} & \multirow{2}{*}{$\begin{array}{l}\text { This mandatory four-character ASCII } \\
\text { value shall be used to specify the current } \\
\text { version number of the standard } \\
\text { implemented by the software or system } \\
\text { creating the transaction. } \\
\text { The format of this field shall consist of } \\
\text { four numeric characters. The first two } \\
\text { characters shall specify the major version } \\
\text { number. The last two characters shall be } \\
\text { used to specify the minor revision number. } \\
\text { In XML, } \\
\text { biom:TransactionMajorVersionValue } \\
\text { is } 5 \text { and } \\
\text { biom:TransactionMinorVersionValue is } 1\end{array}$} & 1 & $\begin{array}{l}\text { 1.002-VER- } \\
\text { Value }\end{array}$ & $\begin{array}{l}\text { EQ } \\
\{\text { Fld }(1.002)\} \\
\text { Str(0501) } \\
\text { ) }\end{array}$ & & M-Fld(1.002) & & & & $\mathrm{T}$ \\
\hline & & & 1 & $\begin{array}{l}\text { NIEM- } \\
\text { 1.002-VER- } \\
\text { Value }\end{array}$ & $\begin{array}{l}\text { AND } \\
( \\
\text { OR } \\
( \\
\text { EQ(\{XElm(1.002.biom:TransactionMajorVersio } \\
\text { nValue)\}, Str(05)), } \\
\text { EQ(\{XElm(1.002.biom:TransactionMajorVersio } \\
\text { nValue })\}, \operatorname{Str}(5)), \\
) \\
\mathrm{EQ}(X E \operatorname{Xim}(1.002 . \text { biom:TransactionMinorVersion } \\
\text { Value), Str(01)), } \\
\text { ) }\end{array}$ & & M-Fld(1.002) & & & & $\mathrm{X}$ \\
\hline $\begin{array}{l}\text { RT1.11 - Fie } \\
\text { ld: } 1.002- \\
\text { VER- } \\
\text { CharType }\end{array}$ & $\begin{array}{c}8.1 \\
\text { Table 22, } \\
8\end{array}$ & $\begin{array}{l}\text { Section } 8.1 \text { and Table } 22 \text { specify the } \\
\text { Character Type for each field. } \\
\text { Numeric values shall not contain leading } \\
\text { zeros unless indicated by the standard text. } \\
\text { Leading zeros are allowed for } 1.002,1.011 \text {, } \\
1.012,99.100 \text {, and } 99.101 \text {. Any dates may } \\
\text { also contain leading zeros. }\end{array}$ & 1 & $\begin{array}{l}\text { 1.002-VER- } \\
\text { CharType }\end{array}$ & $\begin{array}{l}\text { SubSet } \\
\text { Chars }(\{\operatorname{Fld}(1.002)\}) \\
\text { CharNum } \\
\text { ) }\end{array}$ & & M-Fld(1.002) & & & & B \\
\hline \multirow[t]{2}{*}{$\begin{array}{l}\text { RT1.12 - Fie } \\
\text { Id: } 1.002- \\
\text { VER- } \\
\text { CharCount }\end{array}$} & \multirow[t]{2}{*}{ Table 22} & \multirow[t]{2}{*}{$\begin{array}{l}\text { Table } 22 \text { specifies the character count for } \\
\text { each field. }\end{array}$} & 1 & $\begin{array}{l}\text { 1.002-VER- } \\
\text { CharCount }\end{array}$ & $\begin{array}{l}\text { EQ } \\
( \\
\operatorname{Count}(\operatorname{Chars}(\{\operatorname{Fld}(1.002)\}), \\
\text { Int(4) }\end{array}$ & & M-Fld(1.002) & & & & $\mathrm{T}$ \\
\hline & & & 1 & $\begin{array}{l}\text { NIEM- } \\
\text { 1.002-VER- } \\
\text { CharCount }\end{array}$ & $\begin{array}{l}\text { AND } \\
( \\
\text { MO } \\
(\end{array}$ & & M-Fld(1.002) & & & & $\mathrm{X}$ \\
\hline
\end{tabular}




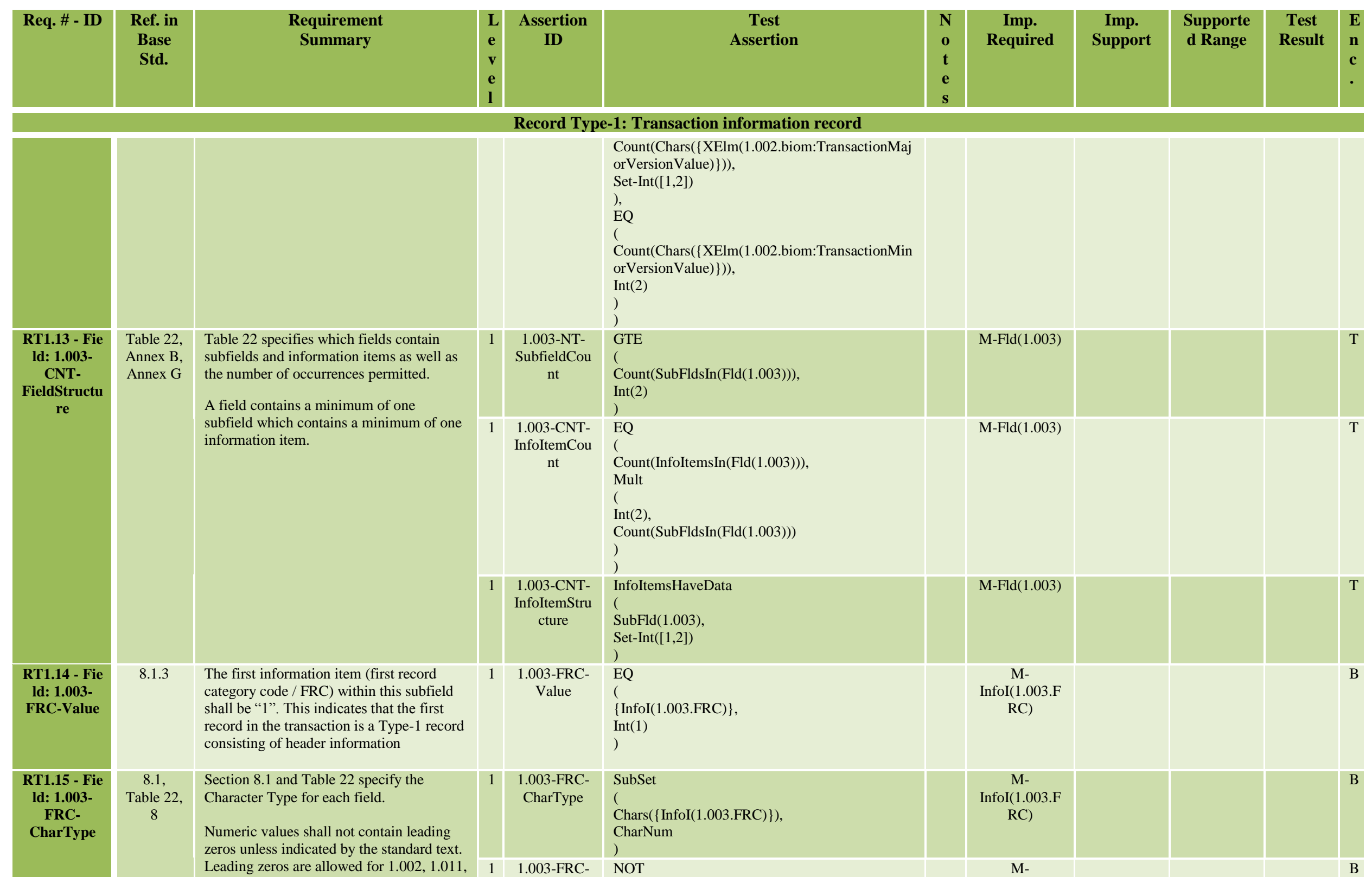




\begin{tabular}{|c|c|c|c|c|c|c|c|c|c|c|c|}
\hline Req. \# - ID & $\begin{array}{c}\text { Ref. in } \\
\text { Base } \\
\text { Std. }\end{array}$ & $\begin{array}{c}\text { Requirement } \\
\text { Summary }\end{array}$ & $\begin{array}{l}\text { L } \\
\text { e } \\
\text { v } \\
\text { e } \\
\text { l }\end{array}$ & $\begin{array}{l}\text { Assertion } \\
\text { ID }\end{array}$ & $\begin{array}{c}\text { Test } \\
\text { Assertion }\end{array}$ & $\begin{array}{l}\mathbf{N} \\
\mathbf{o} \\
\mathrm{t} \\
\mathrm{e} \\
\mathbf{S}\end{array}$ & $\begin{array}{c}\text { Imp. } \\
\text { Required }\end{array}$ & $\begin{array}{c}\text { Imp. } \\
\text { Support }\end{array}$ & $\begin{array}{l}\text { Supporte } \\
\text { d Range }\end{array}$ & $\begin{array}{c}\text { Test } \\
\text { Result }\end{array}$ & $\begin{array}{l}\mathbf{E} \\
\mathbf{n} \\
\mathbf{c} \\
\text {. }\end{array}$ \\
\hline \multicolumn{12}{|c|}{ Record Type-1: Transaction information record } \\
\hline & & $\begin{array}{l}1.012,99.100 \text {, and } 99.101 \text {. Any dates may } \\
\text { also contain leading zeros. }\end{array}$ & & $\begin{array}{l}\text { NoLeadingZ } \\
\text { eros }\end{array}$ & $\begin{array}{l}\text { RegEx } \\
( \\
\{\text { InfoI(1.003.FRC) }\} \\
\text { LeadingZeroNum } \\
)^{\prime}\end{array}$ & & $\begin{array}{l}\text { InfoI(1.003.F } \\
\quad \text { RC) }\end{array}$ & & & & \\
\hline $\begin{array}{l}\text { RT1.16 - Fie } \\
\text { Id: 1.003- } \\
\text { FRC- } \\
\text { CharCount }\end{array}$ & Table 22 & $\begin{array}{l}\text { Table } 22 \text { specifies the character count for } \\
\text { each field. }\end{array}$ & 1 & $\begin{array}{l}\text { 1.003-FRC- } \\
\text { CharCount }\end{array}$ & $\begin{array}{l}\text { EQ } \\
( \\
\operatorname{Count}(\operatorname{Chars}(\{\operatorname{InfoI}(1.003 . \mathrm{FRC})\}), \\
\operatorname{Int}(1)\end{array}$ & & $\begin{array}{c}\text { M- } \\
\text { InfoI(1.003.F } \\
\text { RC) }\end{array}$ & & & & B \\
\hline \multirow[t]{4}{*}{$\begin{array}{l}\text { RT1.17 - Fie } \\
\text { Id: 1.003- } \\
\text { CRC-Value }\end{array}$} & \multirow[t]{4}{*}{$\begin{array}{l}\text { 8.1.3 } \\
\text { Table } 22\end{array}$} & \multirow{4}{*}{$\begin{array}{l}\text { The second information item of this } \\
\text { subfield (content record count / CRC) shall } \\
\text { be the sum of the Type- } 2 \text { through Type- } 99 \\
\text { records contained in this transaction. This } \\
\text { number is also equal to the count of the } \\
\text { remaining subfields of Field } 1.003 \\
\text { Transaction content / CNT. The maximum } \\
\text { value for CRC is } 999 \text {. }\end{array}$} & 1 & $\begin{array}{l}\text { 1.003-CRC- } \\
\text { Value }\end{array}$ & $\begin{array}{l}\text { MO } \\
( \\
\{\text { InfoI(1.003.CRC) }\}, \\
\text { Set-Int([1 to 999]) } \\
{ }^{2}\end{array}$ & & $\begin{array}{c}\text { M- } \\
\text { InfoI(1.003.C } \\
\text { RC) }\end{array}$ & & & & B \\
\hline & & & 2 & $\begin{array}{l}\text { 1.003-CRC- } \\
\text { Value- } \\
\text { Dependent- } \\
\text { RecordCoun } \\
\quad \mathrm{t}\end{array}$ & $\begin{array}{l}\text { EQ } \\
( \\
\{\operatorname{InfoI}(1.003 . \mathrm{CRC})\}, \\
\text { Count(Recs(Set-Int([2 to 99]))) } \\
)\end{array}$ & & $\begin{array}{c}\text { M- } \\
\text { InfoI(1.003.C } \\
\text { RC) }\end{array}$ & & & & B \\
\hline & & & 2 & $\begin{array}{l}\text { 1.003-CRC- } \\
\text { Value- } \\
\text { Dependent- } \\
\text { SubfieldCou } \\
\quad \text { nt }\end{array}$ & $\begin{array}{l}\text { EQ } \\
( \\
\{\operatorname{InfoI}(1.003 . C R C)\} \\
\text { Minus(Count(SubFldsIn(Fld(1.003))), Int(1)) } \\
)\end{array}$ & & $\begin{array}{c}\text { M- } \\
\text { InfoI(1.003.C } \\
\text { RC) }\end{array}$ & & & & $\mathrm{T}$ \\
\hline & & & 2 & $\begin{array}{l}\text { NIEM- } \\
\text { 1.003-CRC- } \\
\text { Value- } \\
\text { Dependent }\end{array}$ & $\begin{array}{l}\text { EQ } \\
( \\
\{X E \operatorname{lm}(1.003 . \text { biom:ContentRecordQuantity })\}, \\
\text { Minus } \\
( \\
\text { Count(ElmsIn( } \\
\text { XElm(1.003.biom:TransactionContentSummary), } \\
\text { XElm(1.003.biom:ContentRecordSummary))), } \\
\text { Int(1) } \\
) \\
)\end{array}$ & & $\begin{array}{c}\text { M- } \\
\text { InfoI(1.003.C } \\
\text { RC) }\end{array}$ & & & & $\mathrm{X}$ \\
\hline
\end{tabular}




\begin{tabular}{|c|c|c|c|c|c|c|c|c|c|c|c|}
\hline Req. \# - ID & $\begin{array}{l}\text { Ref. in } \\
\text { Base } \\
\text { Std. }\end{array}$ & $\begin{array}{l}\text { Requirement } \\
\text { Summary }\end{array}$ & $\begin{array}{l}\mathrm{L} \\
\mathbf{e} \\
\mathrm{v} \\
\mathrm{e} \\
\mathrm{l}\end{array}$ & $\begin{array}{l}\text { Assertion } \\
\text { ID }\end{array}$ & $\begin{array}{c}\text { Test } \\
\text { Assertion }\end{array}$ & $\begin{array}{l}\mathbf{N} \\
\mathbf{o} \\
\mathbf{t} \\
\mathrm{e} \\
\mathrm{S}\end{array}$ & $\begin{array}{l}\text { Imp. } \\
\text { Required }\end{array}$ & $\begin{array}{l}\text { Imp. } \\
\text { Support }\end{array}$ & $\begin{array}{l}\text { Supporte } \\
\text { d Range }\end{array}$ & $\begin{array}{c}\text { Test } \\
\text { Result }\end{array}$ & $\begin{array}{l}\mathbf{E} \\
\mathbf{n} \\
\mathbf{c} \\
\text { - }\end{array}$ \\
\hline \multicolumn{12}{|c|}{ Record Type-1: Transaction information record } \\
\hline \multirow[t]{2}{*}{$\begin{array}{l}\text { RT1.18 - Fie } \\
\text { Id: } 1.003- \\
\text { CRC- } \\
\text { CharType }\end{array}$} & \multirow[t]{2}{*}{$\begin{array}{c}8.1 \\
\text { Table } 22 \\
8\end{array}$} & \multirow{2}{*}{$\begin{array}{l}\text { Section } 8.1 \text { and Table } 22 \text { specify the } \\
\text { Character Type for each field. } \\
\\
\text { Numeric values shall not contain leading } \\
\text { zeros unless indicated by the standard text. } \\
\text { Leading zeros are allowed for } 1.002,1.011 \text {, } \\
1.012,99.100 \text {, and } 99.101 \text {. Any dates may } \\
\text { also contain leading zeros. }\end{array}$} & 1 & $\begin{array}{l}\text { 1.003-CRC- } \\
\text { CharType }\end{array}$ & $\begin{array}{l}\text { SubSet } \\
(\text { Chars(\{InfoI(1.003.CRC) }\}), \\
\text { CharNum } \\
\text { ) }\end{array}$ & & $\begin{array}{l}\text { M- } \\
\text { InfoI(1.003.C } \\
\text { RC) }\end{array}$ & & & & B \\
\hline & & & 1 & $\begin{array}{l}\text { 1.003-CRC- } \\
\text { NoLeadingZ } \\
\quad \text { eros }\end{array}$ & $\begin{array}{l}\text { NOT } \\
( \\
\text { RegEx } \\
( \\
\{\text { InfoI(1.003.CRC) }\} \\
\text { LeadingZeroNum } \\
) \\
)\end{array}$ & & $\begin{array}{l}\text { M- } \\
\text { InfoI }(1.003 . \mathrm{C} \\
\text { RC })\end{array}$ & & & & B \\
\hline $\begin{array}{l}\text { RT1.19 - Fie } \\
\text { Id: } 1.003- \\
\text { CRC- } \\
\text { CharCount }\end{array}$ & Table 22 & $\begin{array}{l}\text { Table } 22 \text { specifies the character count for } \\
\text { each field. }\end{array}$ & 1 & $\begin{array}{l}\text { 1.003-CRC- } \\
\text { CharCount }\end{array}$ & $\begin{array}{l}\text { MO } \\
( \\
\text { Count }(\text { Chars }(\{\operatorname{InfoI}(1.003 . C R C)\}) \text {, } \\
\text { Set-Int([1 to } 2]) \\
)\end{array}$ & & $\begin{array}{l}\text { M- } \\
\text { InfoI(1.003.C } \\
\text { RC) }\end{array}$ & & & & B \\
\hline $\begin{array}{l}\text { RT1.20 - Fie } \\
\text { ld: } 1.003- \\
\text { REC-Value }\end{array}$ & $\begin{array}{l}8.1 .3 \\
\text { Table } 22, \\
\text { Table } 3\end{array}$ & $\begin{array}{l}\text { The first information item (record category } \\
\text { code / REC), shall contain a number } \\
\text { chosen from the "record identifier" column } \\
\text { of Table } 3 \text {. }\end{array}$ & 1 & $\begin{array}{l}\text { 1.003-REC- } \\
\text { Value }\end{array}$ & $\begin{array}{l}\text { MO } \\
(\text { InfoI(1.003.REC) }\} \\
\text { Set-Int([2,4,7 to } 22,98,99]) \\
)\end{array}$ & & $\begin{array}{l}\text { M- } \\
\text { InfoI }(1.003 . R \\
\text { EC) }\end{array}$ & & & & B \\
\hline \multirow[t]{2}{*}{$\begin{array}{l}\text { RT1.21 - Fie } \\
\text { Id: } 1.003- \\
\text { REC- } \\
\text { CharType }\end{array}$} & \multirow[t]{2}{*}{$\begin{array}{c}8.1 \\
\text { Table } 22 \\
8\end{array}$} & \multirow{2}{*}{$\begin{array}{l}\text { Section } 8.1 \text { and Table } 22 \text { specify the } \\
\text { Character Type for each field. } \\
\text { Numeric values shall not contain leading } \\
\text { zeros unless indicated by the standard text. } \\
\text { Leading zeros are allowed for } 1.002,1.011 \text {, } \\
1.012,99.100 \text {, and } 99.101 \text {. Any dates may } \\
\text { also contain leading zeros. }\end{array}$} & 1 & $\begin{array}{l}\text { 1.003-REC- } \\
\text { CharType }\end{array}$ & $\begin{array}{l}\text { SubSet } \\
( \\
\text { Chars( }\{\operatorname{InfoI}(1.003 \cdot \operatorname{REC})\}), \\
\text { CharNum } \\
\text { ) }\end{array}$ & & $\begin{array}{l}\text { M- } \\
\text { InfoI }(1.003 . R \\
\text { EC) }\end{array}$ & & & & B \\
\hline & & & 1 & $\begin{array}{l}\text { 1.003-REC- } \\
\text { NoLeadingZ } \\
\text { eros }\end{array}$ & $\begin{array}{l}\text { NOT } \\
( \\
\text { RegEx } \\
( \\
\{\text { InfoI(1.003.REC) }\} \\
\text { LeadingZeroNum } \\
)_{)}\end{array}$ & & $\begin{array}{c}\text { M- } \\
\text { InfoI(1.003.R } \\
\text { EC) }\end{array}$ & & & & B \\
\hline $\begin{array}{l}\text { RT1.22 - Fie } \\
\text { Id: } 1.003- \\
\text { REC- }\end{array}$ & Table 22 & $\begin{array}{l}\text { Table } 22 \text { specifies the character count for } \\
\text { each field. }\end{array}$ & 1 & $\begin{array}{l}\text { 1.003-REC- } \\
\text { CharCount }\end{array}$ & $\begin{array}{l}\text { MO } \\
( \\
\text { Count }(\operatorname{Chars}(\{\operatorname{InfoI}(1.003 . \mathrm{REC})\}),\end{array}$ & & $\begin{array}{l}\text { M- } \\
\text { InfoI(1.003.R } \\
\text { EC) }\end{array}$ & & & & B \\
\hline
\end{tabular}




\begin{tabular}{|c|c|c|c|c|c|c|c|c|c|c|c|}
\hline Req. \# - ID & $\begin{array}{l}\text { Ref. in } \\
\text { Base } \\
\text { Std. }\end{array}$ & $\begin{array}{l}\text { Requirement } \\
\text { Summary }\end{array}$ & $\begin{array}{l}\text { L } \\
\text { e } \\
\text { v } \\
\text { e } \\
\text { l }\end{array}$ & $\begin{array}{l}\text { Assertion } \\
\text { ID }\end{array}$ & $\begin{array}{c}\text { Test } \\
\text { Assertion }\end{array}$ & $\begin{array}{l}\mathbf{N} \\
\mathbf{o} \\
\mathbf{t} \\
\mathbf{e} \\
\mathbf{S}\end{array}$ & $\begin{array}{c}\text { Imp. } \\
\text { Required }\end{array}$ & $\begin{array}{c}\text { Imp. } \\
\text { Support }\end{array}$ & $\begin{array}{c}\text { Supporte } \\
\text { d Range }\end{array}$ & $\begin{array}{c}\text { Test } \\
\text { Result }\end{array}$ & $\begin{array}{l}\mathbf{E} \\
\mathbf{n} \\
\mathbf{c}\end{array}$ \\
\hline \multicolumn{12}{|c|}{ Record Type-1: Transaction information record } \\
\hline CharCount & & & & & Set-Int $([1,2])$ & & & & & & \\
\hline $\begin{array}{l}\text { RT1.23 - Fie } \\
\text { Id: 1.003- } \\
\text { IDC-Value }\end{array}$ & $\begin{array}{l}8.1 .3 \\
\text { Table } 22\end{array}$ & $\begin{array}{l}\text { The second information item (information } \\
\text { designation character / IDC) shall be an } \\
\text { integer equal to or greater than zero and } \\
\text { less than or equal to } 99 \text {. See } \\
\text { Section 7.3.1. }\end{array}$ & 1 & $\begin{array}{l}\text { 1.003-IDC- } \\
\text { Value }\end{array}$ & $\begin{array}{l}\text { MO } \\
(\text { InfoI(1.003.IDC) }\}, \\
\text { Set-Int([0 to 99]) }\end{array}$ & & $\begin{array}{c}\text { M- } \\
\text { InfoI(1.003.I } \\
\text { DC) }\end{array}$ & & & & B \\
\hline \multirow[t]{2}{*}{$\begin{array}{l}\text { RT1.24 - Fie } \\
\text { Id: } 1.003- \\
\text { IDC- } \\
\text { CharType }\end{array}$} & \multirow[t]{2}{*}{$\begin{array}{c}8.1 \\
\text { Table } 22,\end{array}$} & \multirow{2}{*}{$\begin{array}{l}\text { Section } 8.1 \text { and Table } 22 \text { specify the } \\
\text { Character Type for each field. } \\
\text { Numeric values shall not contain leading } \\
\text { zeros unless indicated by the standard text. } \\
\text { Leading zeros are allowed for } 1.002,1.011 \text {, } \\
1.012,99.100 \text {, and } 99.101 \text {. Any dates may } \\
\text { also contain leading zeros. }\end{array}$} & 1 & $\begin{array}{l}\text { 1.003-IDC- } \\
\text { CharType }\end{array}$ & $\begin{array}{l}\text { SubSet } \\
( \\
\text { Chars }(\{\operatorname{InfoI}(1.003 . \mathrm{IDC})\}), \\
\text { CharNum } \\
\text { ) }\end{array}$ & & $\begin{array}{c}\text { M- } \\
\text { InfoI(1.003.I } \\
\text { DC) }\end{array}$ & & & & B \\
\hline & & & 1 & $\begin{array}{l}\text { 1.003-IDC- } \\
\text { NoLeadingZ } \\
\text { eros }\end{array}$ & $\begin{array}{l}\text { NOT } \\
( \\
\text { RegEx } \\
(\text { InfoI(1.003.IDC) }\} \\
\text { LeadingZeroNum } \\
) \\
)\end{array}$ & & $\begin{array}{c}\text { M- } \\
\text { InfoI(1.003.I } \\
\text { DC) }\end{array}$ & & & & B \\
\hline $\begin{array}{l}\text { RT1.25 - Fie } \\
\text { ld: } 1.003- \\
\text { IDC- } \\
\text { CharCount }\end{array}$ & Table 22 & $\begin{array}{l}\text { Table } 22 \text { specifies the character count for } \\
\text { each field. }\end{array}$ & 1 & $\begin{array}{l}\text { 1.003-IDC- } \\
\text { CharCount }\end{array}$ & $\begin{array}{l}\text { MO } \\
( \\
\text { Count }(\text { Chars }(\{\operatorname{InfoI}(1.003 . \mathrm{IDC})\}), \\
\text { Set-Int }([1,2]) \\
)\end{array}$ & & $\begin{array}{l}\text { M- } \\
\text { InfoI }(1.003 . \mathrm{I} \\
\text { DC })\end{array}$ & & & & B \\
\hline \multirow[t]{2}{*}{$\begin{array}{l}\text { RT1.26 - Fie } \\
\text { Id: } 1.004- \\
\text { TOT- } \\
\text { FieldStructu } \\
\text { re }\end{array}$} & \multirow[t]{2}{*}{$\begin{array}{l}\text { Table 22, } \\
\text { Annex B, } \\
\text { Annex G }\end{array}$} & \multirow{2}{*}{$\begin{array}{l}\text { Table } 22 \text { specifies which fields contain } \\
\text { subfields and information items as well as } \\
\text { the number of occurrences permitted. } \\
\text { A field contains a minimum of one } \\
\text { subfield which contains a minimum of one } \\
\text { information item. }\end{array}$} & 1 & $\begin{array}{c}\text { 1.004-TOT- } \\
\text { SubfieldCou } \\
\text { nt }\end{array}$ & $\begin{array}{l}\text { EQ } \\
( \\
\text { Count(SubFldsIn(Fld(1.004))), } \\
\text { Int(1) }\end{array}$ & & M-Fld(1.004) & & & & $\mathrm{T}$ \\
\hline & & & 1 & $\begin{array}{c}\text { 1.004-TOT- } \\
\text { InfoItemCou } \\
\mathrm{nt}\end{array}$ & $\begin{array}{l}\text { EQ } \\
( \\
\text { Count(InfoItemsIn(SubFld(1.004.1))), } \\
\text { Int(1) }\end{array}$ & & M-Fld(1.004) & & & & $\mathrm{T}$ \\
\hline $\begin{array}{l}\text { RT1.27 - Fie } \\
\text { Id: } 1.004- \\
\text { TOT-Value }\end{array}$ & $\begin{array}{l}8.1 .4 \\
\text { Table } 22\end{array}$ & $\begin{array}{l}\text { This mandatory field shall contain an } \\
\text { identifier, which designates the type of } \\
\text { transaction and subsequent processing that } \\
\text { this transaction should be given. This shall } \\
\text { be a maximum of } 16 \text { alphabetic characters. } \\
\text { The TOT shall be in accordance with }\end{array}$ & 1 & $\begin{array}{l}\text { 1.004-TOT- } \\
\text { Value }\end{array}$ & $\begin{array}{l}\text { ReturnResult } \\
( \\
\text { Result(Pass) } \\
\text { ) }\end{array}$ & & M-Fld(1.004) & & & & B \\
\hline
\end{tabular}




\begin{tabular}{|c|c|c|c|c|c|c|c|c|c|c|c|}
\hline Req. \# - ID & $\begin{array}{l}\text { Ref. in } \\
\text { Base } \\
\text { Std. }\end{array}$ & $\begin{array}{l}\text { Requirement } \\
\text { Summary }\end{array}$ & $\begin{array}{l}\text { L } \\
\text { e } \\
\text { v } \\
\text { e } \\
\text { l }\end{array}$ & $\begin{array}{l}\text { Assertion } \\
\text { ID }\end{array}$ & $\begin{array}{c}\text { Test } \\
\text { Assertion }\end{array}$ & $\begin{array}{l}\mathbf{N} \\
\mathbf{o} \\
\mathbf{t} \\
\mathbf{e} \\
\mathbf{S}\end{array}$ & $\begin{array}{c}\text { Imp. } \\
\text { Required }\end{array}$ & $\begin{array}{c}\text { Imp. } \\
\text { Support }\end{array}$ & $\begin{array}{c}\text { Supporte } \\
\text { d Range }\end{array}$ & $\begin{array}{c}\text { Test } \\
\text { Result }\end{array}$ & $\begin{array}{l}\mathbf{E} \\
\mathbf{n} \\
\mathbf{c} \\
\text {. }\end{array}$ \\
\hline \multicolumn{12}{|c|}{ Record Type-1: Transaction information record } \\
\hline & & $\begin{array}{l}\text { definitions provided by the receiving } \\
\text { agency.) Earlier versions of this standard } \\
\text { specifically restricted the character length } \\
\text { of TOT to } 4 \text { characters. }\end{array}$ & & & & & & & & & \\
\hline $\begin{array}{l}\text { RT1.28 - Fie } \\
\text { Id: } 1.004- \\
\text { TOT- } \\
\text { CharType }\end{array}$ & $\begin{array}{c}8.1 \\
\text { Table 22, }\end{array}$ & $\begin{array}{l}\text { Section } 8.1 \text { and Table } 22 \text { specify the } \\
\text { Character Type for each field. }\end{array}$ & 1 & $\begin{array}{l}\text { 1.004-TOT- } \\
\text { CharType }\end{array}$ & $\begin{array}{l}\text { SubSet } \\
(\text { Chars(\{Fld(1.004)\}), } \\
\text { CharAlpha } \\
\text { ) }\end{array}$ & & M-Fld(1.004) & & & & B \\
\hline $\begin{array}{l}\text { RT1.29 - Fie } \\
\text { Id: } 1.004- \\
\text { TOT- } \\
\text { CharCount }\end{array}$ & Table 22 & $\begin{array}{l}\text { Table } 22 \text { specifies the character count for } \\
\text { each field. }\end{array}$ & 1 & $\begin{array}{l}\text { 1.004-TOT- } \\
\text { CharCount }\end{array}$ & $\begin{array}{l}\text { MO } \\
( \\
\text { Count(Chars(\{Fld(1.004)\}), } \\
\text { Set-Int([1 to } 16])\end{array}$ & & M-Fld(1.004) & & & & B \\
\hline \multirow[t]{2}{*}{$\begin{array}{l}\text { RT1.30 - Fie } \\
\text { Id: } 1.005- \\
\text { DAT- } \\
\text { FieldStructu } \\
\quad \text { re }\end{array}$} & \multirow[t]{2}{*}{$\begin{array}{l}\text { Table 22, } \\
\text { Annex B, } \\
\text { Annex G }\end{array}$} & \multirow{2}{*}{$\begin{array}{l}\text { Table } 22 \text { specifies which fields contain } \\
\text { subfields and information items as well as } \\
\text { the number of occurrences permitted. } \\
\text { A field contains a minimum of one } \\
\text { subfield which contains a minimum of one } \\
\text { information item. }\end{array}$} & 1 & $\begin{array}{c}\text { 1.005-DAT- } \\
\text { SubfieldCou } \\
\text { nt }\end{array}$ & $\begin{array}{l}\text { EQ } \\
(\text { Count(SubFldsIn(Fld(1.005))), } \\
\text { Int(1) }\end{array}$ & & M-Fld(1.005) & & & & $\mathrm{T}$ \\
\hline & & & 1 & $\begin{array}{c}\text { 1.005-DAT- } \\
\text { InfoItemCou } \\
\text { nt }\end{array}$ & $\begin{array}{l}\text { EQ } \\
(\text { Count(InfoItemsIn(SubFld(1.005.1))), } \\
\text { Int(1) }\end{array}$ & & M-Fld(1.005) & & & & $\mathrm{T}$ \\
\hline \multirow[t]{2}{*}{$\begin{array}{l}\text { RT1.31 - Fie } \\
\text { Id: } 1.005- \\
\text { DAT-Value }\end{array}$} & \multirow[t]{2}{*}{$\begin{array}{l}\text { 8.1.5, } \\
\text { Table 22, } \\
7.7 .2 .3\end{array}$} & \multirow[t]{2}{*}{$\begin{array}{l}\text { This mandatory field shall contain the local } \\
\text { date that the transaction was submitted. } \\
\text { The local date is recorded as } \\
\text { YYYYMMDD. Note that this may be a } \\
\text { different date than the corresponding } \\
\text { GMT, due to time zone differences. }\end{array}$} & 1 & $\begin{array}{l}\text { 1.005-DAT- } \\
\text { Value }\end{array}$ & $\begin{array}{l}\text { Complex } \\
( \\
\text { EQ } \\
( \\
\{\text { Fld }(1.005)\} \\
\text { ValidLocalDate } \\
))\end{array}$ & $\mathrm{t} 3$ & M-Fld(1.005) & & & & $\mathrm{T}$ \\
\hline & & & 1 & $\begin{array}{l}\text { NIEM- } \\
\text { 1.005-DAT- } \\
\text { Value }\end{array}$ & $\begin{array}{l}\text { Complex } \\
\text { IfThenElse } \\
( \\
\text { Present(XElm(1.005.nc:Date)), } \\
\text { EQ(\{XElm(1.005.nc:Date }\}, \text { NIEM- } \\
\text { ValidLocalDate), } \\
\text { IfThenElse } \\
\text { ( } \\
\text { Present(XElm(1.005.nc:YearMonth)), } \\
\text { EQ(\{XElm(1.005.nc:YearMonth)\}, NIEM- }\end{array}$ & $\mathrm{t} 3$ & M-Fld(1.005) & & & & $\mathrm{X}$ \\
\hline
\end{tabular}




\begin{tabular}{|c|c|c|c|c|c|c|c|c|c|c|c|}
\hline Req. \# - ID & $\begin{array}{l}\text { Ref. in } \\
\text { Base } \\
\text { Std. }\end{array}$ & $\begin{array}{l}\text { Requirement } \\
\text { Summary }\end{array}$ & $\begin{array}{l}\text { L } \\
\text { e } \\
\text { v } \\
\text { e } \\
\text { l }\end{array}$ & $\begin{array}{l}\text { Assertion } \\
\text { ID }\end{array}$ & $\begin{array}{c}\text { Test } \\
\text { Assertion }\end{array}$ & $\begin{array}{l}\mathbf{N} \\
\mathbf{0} \\
\mathbf{t} \\
\mathbf{e} \\
\mathbf{S}\end{array}$ & $\begin{array}{c}\text { Imp. } \\
\text { Required }\end{array}$ & $\begin{array}{c}\text { Imp. } \\
\text { Support }\end{array}$ & $\begin{array}{l}\text { Supporte } \\
\text { d Range }\end{array}$ & $\begin{array}{c}\text { Test } \\
\text { Result }\end{array}$ & $\begin{array}{l}\mathbf{E} \\
\mathbf{n} \\
\mathbf{c} \\
.\end{array}$ \\
\hline \multicolumn{12}{|c|}{ Record Type-1: Transaction information record } \\
\hline & & & & & $\begin{array}{l}\text { ValidLocalYearMonth), } \\
\text { IfThenElse } \\
\text { ( } \\
\text { Present(XElm(1.005.nc:Year)), } \\
\text { EQ(\{XElm(1.005.nc:Year)\}, NIEM- } \\
\text { ValidLocalYear), } \\
\text { ReturnResult } \\
\text { ( } \\
\text { Result(Fail(No valid local date element is } \\
\text { present.)) } \\
)))) \\
\text { ) }\end{array}$ & & & & & & \\
\hline \multirow[t]{2}{*}{$\begin{array}{l}\text { RT1.32 - Fie } \\
\text { Id: } 1.005- \\
\text { DAT- } \\
\text { CharType }\end{array}$} & \multirow[t]{2}{*}{$\begin{array}{c}8.1 \\
\text { Table 22, }\end{array}$} & \multirow{2}{*}{$\begin{array}{l}\text { Section } 8.1 \text { and Table } 22 \text { specify the } \\
\text { Character Type for each field. } \\
\text { Numeric values shall not contain leading } \\
\text { zeros unless indicated by the standard text. } \\
\text { Leading zeros are allowed for } 1.002,1.011 \text {, } \\
1.012,99.100 \text {, and } 99.101 \text {. Any dates may } \\
\text { also contain leading zeros. }\end{array}$} & 1 & $\begin{array}{l}\text { 1.005-DAT- } \\
\text { CharType }\end{array}$ & $\begin{array}{l}\text { SubSet } \\
( \\
\text { Chars(\{Fld(1.005)\}), } \\
\text { CharNum } \\
\text { ) }\end{array}$ & & M-Fld(1.005) & & & & $\mathrm{T}$ \\
\hline & & & 1 & $\begin{array}{l}\text { NIEM- } \\
\text { 1.005-DAT- } \\
\text { CharType }\end{array}$ & $\begin{array}{l}\text { IfThenElse } \\
( \\
\text { Present(XElm(1.005.nc:Date)), } \\
\text { SubSet } \\
\text { ( } \\
\text { Chars(\{XElm(1.005.nc:Date)\}) } \\
\text { Union(CharNum, Set-Str([-])) } \\
\text { ), } \\
\text { IfThenElse } \\
\text { ( } \\
\text { Present(XElm(1.005.nc:YearMonth)), } \\
\text { SubSet } \\
\text { ( } \\
\text { Chars(\{XElm(1.005.nc:YearMonth)\}) } \\
\text { Union(CharNum, Set-Str([-])) } \\
\text { ), } \\
\text { IfThenElse } \\
\text { ( } \\
\text { Present(XElm(1.005.nc:Year)), } \\
\text { SubSet } \\
\text { ( } \\
\text { Chars(\{XElm(1.005.nc:Year)\}) } \\
\text { CharNum } \\
), \\
\text { ReturnResult } \\
\text { ( }\end{array}$ & & M-Fld(1.005) & & & & $\mathrm{X}$ \\
\hline
\end{tabular}




\begin{tabular}{|c|c|c|c|c|c|c|c|c|c|c|c|}
\hline Req. \# - ID & $\begin{array}{c}\text { Ref. in } \\
\text { Base } \\
\text { Std. }\end{array}$ & $\begin{array}{l}\text { Requirement } \\
\text { Summary }\end{array}$ & $\begin{array}{l}\text { L } \\
\text { e } \\
\text { v } \\
\text { e } \\
\text { l }\end{array}$ & $\begin{array}{l}\text { Assertion } \\
\text { ID }\end{array}$ & $\begin{array}{c}\text { Test } \\
\text { Assertion }\end{array}$ & $\begin{array}{l}\mathbf{N} \\
\mathbf{o} \\
\mathbf{t} \\
\mathbf{e} \\
\mathbf{S}\end{array}$ & $\begin{array}{l}\text { Imp. } \\
\text { Required }\end{array}$ & $\begin{array}{l}\text { Imp. } \\
\text { Support }\end{array}$ & $\begin{array}{l}\text { Supporte } \\
\text { d Range }\end{array}$ & $\begin{array}{c}\text { Test } \\
\text { Result }\end{array}$ & $\begin{array}{l}\mathbf{E} \\
\mathbf{n} \\
\mathbf{c} \\
.\end{array}$ \\
\hline \multicolumn{12}{|c|}{ Record Type-1: Transaction information record } \\
\hline & & & & & $\begin{array}{l}\text { Result(Fail(No valid local date element is } \\
\text { present.)) } \\
\text { ())) }\end{array}$ & & & & & & \\
\hline \multirow[t]{2}{*}{$\begin{array}{l}\text { RT1.33 - Fie } \\
\text { Id: 1.005- } \\
\text { DAT- } \\
\text { CharCount }\end{array}$} & \multirow[t]{2}{*}{ Table 22} & \multirow[t]{2}{*}{$\begin{array}{l}\text { Table } 22 \text { specifies the character count for } \\
\text { each field. }\end{array}$} & 1 & $\begin{array}{l}\text { 1.005-DAT- } \\
\text { CharCount }\end{array}$ & $\begin{array}{l}\text { EQ } \\
\text { Count }(\operatorname{Chars}(\{\operatorname{Fld}(1.005)\}) \\
)\end{array}$ & & M-Fld(1.005) & & & & $\mathrm{T}$ \\
\hline & & & 1 & $\begin{array}{l}\text { NIEM- } \\
\text { 1.005-DAT- } \\
\text { CharCount }\end{array}$ & $\begin{array}{l}\text { IfThenElse } \\
\text { Present(XElm(1.005.nc:Date)), } \\
\text { EQ } \\
(\text { Count(Chars(\{XElm(1.005.nc:Date) }\})) \\
\text { Int(10) } \\
), \\
\text { IfThenElse } \\
(\text { Present(XElm(1.005.nc:YearMonth)), } \\
\text { EQ } \\
( \\
\text { Count(Chars(\{XElm(1.005.nc:YearMonth) }\})) \\
\text { Int(7) } \\
), \\
\text { IfThenElse } \\
( \\
\text { Present(XElm(1.005.nc:Year)), } \\
\text { EQ } \\
(\text { Count(Chars(\{XElm(1.005.nc:Year) }\})) \\
\text { Int(4) } \\
), \\
\text { ReturnResult } \\
\text { ( } \\
\text { Result(Fail(No valid local date element is } \\
\text { present. }))\end{array}$ & & M-Fld(1.005) & & & & $\mathrm{X}$ \\
\hline $\begin{array}{l}\text { RT1.34 - Fie } \\
\text { Id: } 1.006- \\
\text { PRY- } \\
\text { FieldStructu } \\
\quad \text { re }\end{array}$ & $\begin{array}{l}\text { Table 22, } \\
\text { Annex B, } \\
\text { Annex G }\end{array}$ & $\begin{array}{l}\text { Table } 22 \text { specifies which fields contain } \\
\text { subfields and information items as well as } \\
\text { the number of occurrences permitted. } \\
\text { A field contains a minimum of one }\end{array}$ & 1 & $\begin{array}{c}\text { 1.006-PRY- } \\
\text { SubfieldCou } \\
\text { nt }\end{array}$ & $\begin{array}{l}\text { EQ } \\
\text { Count( }(1)\end{array}$ & & O-Fld(1.006) & & & & $\mathrm{T}$ \\
\hline
\end{tabular}




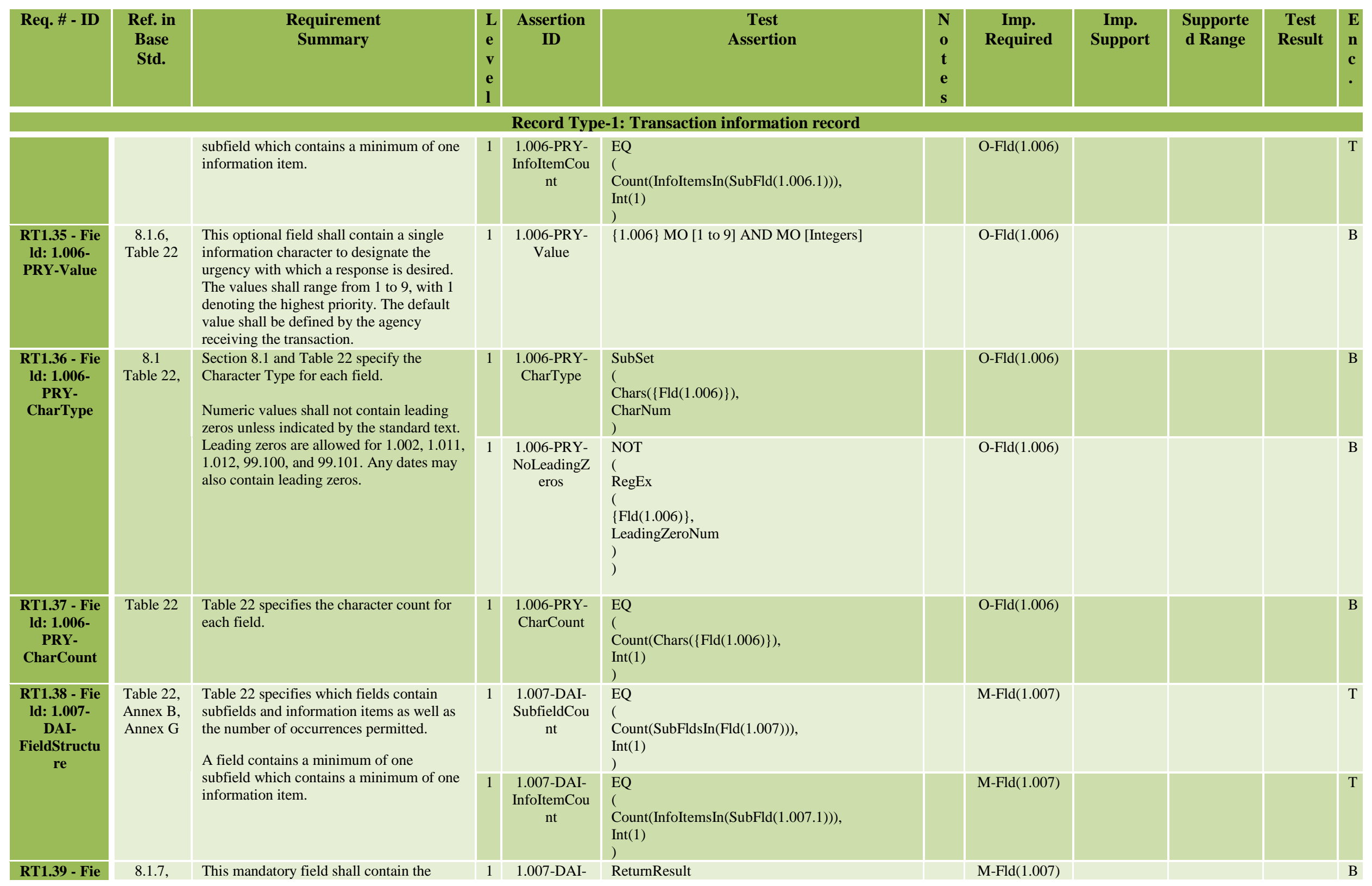




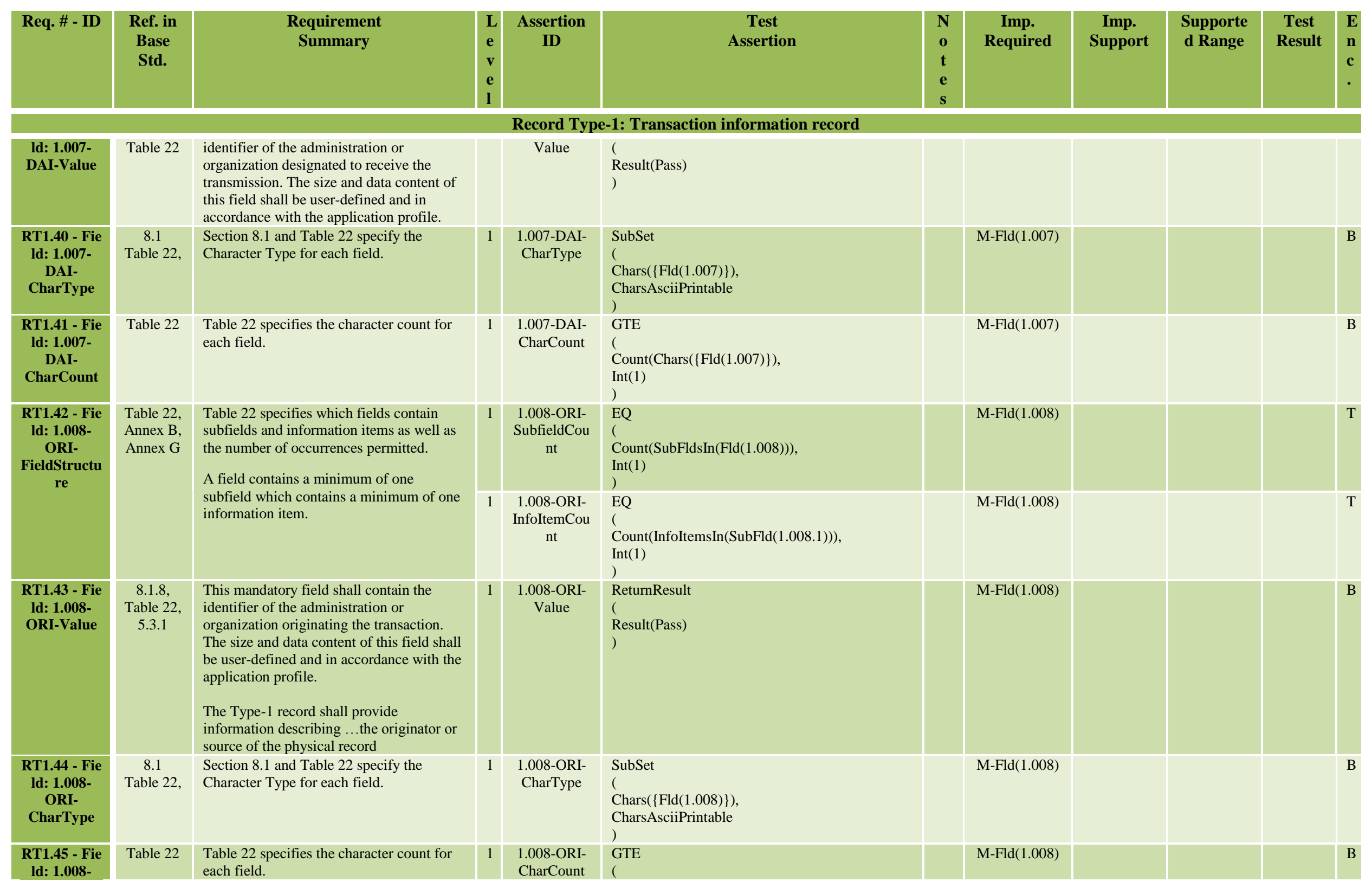




\begin{tabular}{|c|c|c|c|c|c|c|c|c|c|c|c|}
\hline Req. \# - ID & $\begin{array}{l}\text { Ref. in } \\
\text { Base } \\
\text { Std. }\end{array}$ & $\begin{array}{l}\text { Requirement } \\
\text { Summary }\end{array}$ & $\begin{array}{l}\text { L } \\
\text { e } \\
\text { v } \\
\text { e } \\
\text { l }\end{array}$ & $\begin{array}{l}\text { Assertion } \\
\text { ID }\end{array}$ & $\begin{array}{c}\text { Test } \\
\text { Assertion }\end{array}$ & $\begin{array}{l}\mathbf{N} \\
\mathbf{o} \\
\mathbf{t} \\
\mathbf{e} \\
\mathbf{S}\end{array}$ & $\begin{array}{l}\text { Imp. } \\
\text { Required }\end{array}$ & $\begin{array}{l}\text { Imp. } \\
\text { Support }\end{array}$ & $\begin{array}{l}\text { Supporte } \\
\text { d Range }\end{array}$ & $\begin{array}{l}\text { Test } \\
\text { Result }\end{array}$ & $\begin{array}{l}\mathbf{E} \\
\mathbf{n} \\
\mathbf{c} \\
\text {. }\end{array}$ \\
\hline \multicolumn{12}{|c|}{ Record Type-1: Transaction information record } \\
\hline $\begin{array}{c}\text { ORI- } \\
\text { CharCount }\end{array}$ & & & & & $\begin{array}{l}\text { Count }(\operatorname{Chars}(\{\operatorname{Fld}(1.008)\}) \text {, } \\
\text { Int(1) }\end{array}$ & & & & & & \\
\hline \multirow[t]{2}{*}{$\begin{array}{l}\text { RT1.46 - Fie } \\
\text { ld: } 1.009- \\
\text { TCN- } \\
\text { FieldStructu } \\
\text { re }\end{array}$} & \multirow[t]{2}{*}{$\begin{array}{l}\text { Table 22, } \\
\text { Annex B, } \\
\text { Annex G }\end{array}$} & \multirow{2}{*}{$\begin{array}{l}\text { Table } 22 \text { specifies which fields contain } \\
\text { subfields and information items as well as } \\
\text { the number of occurrences permitted. } \\
\text { A field contains a minimum of one } \\
\text { subfield which contains a minimum of one } \\
\text { information item. }\end{array}$} & 1 & $\begin{array}{l}\text { 1.009-TCN- } \\
\text { SubfieldCou } \\
\text { nt }\end{array}$ & $\begin{array}{l}\text { EQ } \\
( \\
\text { Count(SubFldsIn(Fld(1.009))), } \\
\text { Int(1) }\end{array}$ & & M-Fld(1.009) & & & & $\mathrm{T}$ \\
\hline & & & 1 & $\begin{array}{l}\text { 1.009-TCN- } \\
\text { InfoItemCou } \\
\text { nt }\end{array}$ & $\begin{array}{l}\text { EQ } \\
( \\
\text { Count(InfoItemsIn(SubFld(1.009.1))), } \\
\text { Int(1) }\end{array}$ & & M-Fld(1.009) & & & & $\mathrm{T}$ \\
\hline $\begin{array}{l}\text { RT1.47 - Fie } \\
\text { Id: 1.009- } \\
\text { TCN-Value }\end{array}$ & $\begin{array}{l}8.1 .9 \\
\text { Table } 22\end{array}$ & $\begin{array}{l}\text { This mandatory field shall contain the } \\
\text { transaction control number as assigned by } \\
\text { the originating agency. A unique (for the } \\
\text { originating agency) alphanumeric control } \\
\text { number shall be assigned to each } \\
\text { transaction. For any transaction that } \\
\text { requires a response, the respondent shall } \\
\text { refer to this number in communicating with } \\
\text { the originating agency. }\end{array}$ & 1 & $\begin{array}{l}\text { 1.009-TCN- } \\
\text { Value }\end{array}$ & $\begin{array}{l}\text { ReturnResult } \\
( \\
\text { Result(Pass) } \\
\text { ) }\end{array}$ & & M-Fld(1.009) & & & & B \\
\hline $\begin{array}{l}\text { RT1.48 - Fie } \\
\text { Id: } 1.009- \\
\text { TCN- } \\
\text { CharType }\end{array}$ & $\begin{array}{c}8.1 \\
\text { Table 22, }\end{array}$ & $\begin{array}{l}\text { Section } 8.1 \text { and Table } 22 \text { specify the } \\
\text { Character Type for each field. }\end{array}$ & 1 & $\begin{array}{l}\text { 1.009-TCN- } \\
\text { CharType }\end{array}$ & $\begin{array}{l}\text { SubSet } \\
(\text { Chars(\{Fld(1.009)\}), } \\
\text { CharsAsciiPrintable } \\
\text { ) }\end{array}$ & & M-Fld(1.009) & & & & B \\
\hline $\begin{array}{l}\text { RT1.49 - Fie } \\
\text { Id: } 1.009- \\
\text { TCN- } \\
\text { CharCount }\end{array}$ & Table 22 & $\begin{array}{l}\text { Table } 22 \text { specifies the character count for } \\
\text { each field. }\end{array}$ & 1 & $\begin{array}{l}1.009-\mathrm{TCN}- \\
\text { CharCount }\end{array}$ & $\begin{array}{l}\text { GTE } \\
( \\
\text { Count }(\operatorname{Chars}(\{\operatorname{Fld}(1.009)\}), \\
\text { Int(1) } \\
)\end{array}$ & & M-Fld(1.009) & & & & B \\
\hline \multirow[t]{2}{*}{$\begin{array}{l}\text { RT1.50 - Fie } \\
\text { ld: } 1.010- \\
\text { TCR- } \\
\text { FieldStructu } \\
\text { re }\end{array}$} & \multirow[t]{2}{*}{$\begin{array}{l}\text { Table 22, } \\
\text { Annex B, } \\
\text { Annex G }\end{array}$} & \multirow{2}{*}{$\begin{array}{l}\text { Table } 22 \text { specifies which fields contain } \\
\text { subfields and information items as well as } \\
\text { the number of occurrences permitted. } \\
\text { A field contains a minimum of one } \\
\text { subfield which contains a minimum of one } \\
\text { information item. }\end{array}$} & 1 & $\begin{array}{l}\text { 1.010-TCR- } \\
\text { SubfieldCou } \\
\text { nt }\end{array}$ & $\begin{array}{l}\text { EQ } \\
( \\
\text { Count(SubFldsIn(Fld(1.010))), } \\
\text { Int(1) }\end{array}$ & & O-Fld(1.010) & & & & $\mathrm{T}$ \\
\hline & & & 1 & $\begin{array}{c}\text { 1.010-TCR- } \\
\text { InfoItemCou } \\
\mathrm{nt}\end{array}$ & $\begin{array}{l}\text { EQ } \\
(\text { Count(InfoItemsIn(SubFld(1.010.1))), } \\
\text { Int(1) }\end{array}$ & & O-Fld(1.010) & & & & $\mathrm{T}$ \\
\hline
\end{tabular}




\begin{tabular}{|c|c|c|c|c|c|c|c|c|c|c|c|}
\hline Req. \# - ID & $\begin{array}{l}\text { Ref. in } \\
\text { Base } \\
\text { Std. }\end{array}$ & $\begin{array}{l}\text { Requirement } \\
\text { Summary }\end{array}$ & $\begin{array}{l}\text { L } \\
\text { e } \\
\text { v } \\
\text { e } \\
\text { l }\end{array}$ & $\begin{array}{l}\text { Assertion } \\
\text { ID }\end{array}$ & $\begin{array}{c}\text { Test } \\
\text { Assertion }\end{array}$ & $\begin{array}{l}\mathbf{N} \\
\mathbf{o} \\
\mathbf{t} \\
\mathbf{e} \\
\mathbf{S}\end{array}$ & $\begin{array}{c}\text { Imp. } \\
\text { Required }\end{array}$ & $\begin{array}{c}\text { Imp. } \\
\text { Support }\end{array}$ & $\begin{array}{l}\text { Supporte } \\
\text { d Range }\end{array}$ & $\begin{array}{c}\text { Test } \\
\text { Result }\end{array}$ & $\begin{array}{l}\mathbf{E} \\
\mathbf{n} \\
\mathbf{c} \\
\text {. }\end{array}$ \\
\hline \multicolumn{12}{|c|}{ Record Type-1: Transaction information record } \\
\hline $\begin{array}{l}\text { RT1.51 - Fie } \\
\text { ld: } 1.010- \\
\text { TCR-Value }\end{array}$ & $\begin{array}{l}8.1 .10 \\
\text { Table } 22\end{array}$ & $\begin{array}{l}\text { This optional field shall be used for } \\
\text { responses that refer to the TCN of a } \\
\text { previous transaction involving an inquiry } \\
\text { or other action that required a response. }\end{array}$ & 1 & $\begin{array}{l}\text { 1.010-TCR- } \\
\text { Value }\end{array}$ & $\begin{array}{l}\text { ReturnResult } \\
( \\
\text { Result(Pass) }\end{array}$ & & O-Fld(1.010) & & & & B \\
\hline $\begin{array}{l}\text { RT1.52 - Fie } \\
\text { Id: } 1.010- \\
\text { TCR- } \\
\text { CharType }\end{array}$ & $\begin{array}{c}8.1 \\
\text { Table 22, }\end{array}$ & $\begin{array}{l}\text { Section } 8.1 \text { and Table } 22 \text { specify the } \\
\text { Character Type for each field. }\end{array}$ & 1 & $\begin{array}{l}\text { 1.010-TCR- } \\
\text { CharType }\end{array}$ & $\begin{array}{l}\text { SubSet } \\
(\text { Chars(\{Fld(1.010)\}), } \\
\text { CharsAsciiPrintable } \\
\text { ) }\end{array}$ & & O-Fld(1.010) & & & & B \\
\hline $\begin{array}{l}\text { RT1.53 - Fie } \\
\text { Id: } 1.010- \\
\text { TCR- } \\
\text { CharCount }\end{array}$ & Table 22 & $\begin{array}{l}\text { Table } 22 \text { specifies the character count for } \\
\text { each field. }\end{array}$ & 1 & $\begin{array}{l}\text { 1.010-TCR- } \\
\text { CharCount }\end{array}$ & $\begin{array}{l}\text { GTE } \\
( \\
\text { Count }(\operatorname{Chars}(\{\operatorname{Fld}(1.010)\}), \\
\text { Int(1) }\end{array}$ & & O-Fld(1.010) & & & & B \\
\hline \multirow[t]{2}{*}{$\begin{array}{l}\text { RT1.54 - Fie } \\
\text { Id: } 1.011- \\
\text { NSR- } \\
\text { FieldStructu } \\
\text { re }\end{array}$} & \multirow[t]{2}{*}{$\begin{array}{l}\text { Table 22, } \\
\text { Annex B, } \\
\text { Annex G }\end{array}$} & \multirow{2}{*}{$\begin{array}{l}\text { Table } 22 \text { specifies which fields contain } \\
\text { subfields and information items as well as } \\
\text { the number of occurrences permitted. } \\
\text { A field contains a minimum of one } \\
\text { subfield which contains a minimum of one } \\
\text { information item. }\end{array}$} & 1 & $\begin{array}{c}\text { 1.011-NSR- } \\
\text { SubfieldCou } \\
\text { nt }\end{array}$ & $\begin{array}{l}\text { EQ } \\
( \\
\text { Count(SubFldsIn(Fld(1.011))), } \\
\text { Int(1) }\end{array}$ & & M-Fld(1.011) & & & & $\mathrm{T}$ \\
\hline & & & 1 & $\begin{array}{c}\text { 1.011-NSR- } \\
\text { InfoItemCou } \\
\mathrm{nt}\end{array}$ & $\begin{array}{l}\text { EQ } \\
( \\
\text { Count(InfoItemsIn(SubFld(1.011.1))), } \\
\text { Int }(1)\end{array}$ & & M-Fld(1.011) & & & & $\mathrm{T}$ \\
\hline \multirow[t]{3}{*}{$\begin{array}{l}\text { RT1.55 - Fie } \\
\text { Id: 1.011- } \\
\text { NSR-Value }\end{array}$} & \multirow[t]{3}{*}{$\begin{array}{l}\text { 8.1.11, } \\
\text { Table } 22, \\
7.7 .6, \\
7.7 .6 .1, \\
7.7 .6 .2 .1, \\
\text { Table } 14\end{array}$} & \multirow{3}{*}{$\begin{array}{l}\text { This mandatory field shall be set to } \\
\text { " } 00.00 \text { " if there are no Type- } 4 \text { records in } \\
\text { the transaction. } \\
\text { When there are Type- } 4 \text { records present, } \\
\text { this field is used to specify the native } \\
\text { scanning resolution of the friction ridge } \\
\text { image capture device. This field shall } \\
\text { specify the resolution in pixels per } \\
\text { millimeter. The resolution shall be } \\
\text { expressed as two numeric characters } \\
\text { followed by a decimal point and two more } \\
\text { numeric characters. } \\
\text { Images with scanning resolution greater } \\
\text { than or equal to the } 1000 \text { ppi class should } \\
\text { not be transmitted using Record Type- } 4 \\
\text { unless being transmitted at } 500 \text { ppi class to } \\
\text { a system incapable of receiving Type- } 14\end{array}$} & 1 & $\begin{array}{l}\text { 1.011-NSR- } \\
\text { Value }\end{array}$ & $\begin{array}{l}\operatorname{RegEx} \\
( \\
\{\operatorname{Fld}(1.011)\}, \\
\operatorname{Str}(\wedge[0-9]\{2\} \backslash .[0-9]\{2\} \$) \\
)\end{array}$ & & M-Fld(1.011) & & & & $\mathrm{T}$ \\
\hline & & & 1 & $\begin{array}{l}\text { NIEM- } \\
\text { 1.011-NSR- } \\
\text { Value }\end{array}$ & $\begin{array}{l}\text { RegEx } \\
( \\
\{\operatorname{Fld}(1.011)\}, \\
\operatorname{Str}(\wedge[0-9]\{1,2\} \backslash .[0-9]\{2\} \$) \\
)\end{array}$ & & M-Fld(1.011) & & & & $\mathrm{X}$ \\
\hline & & & 2 & $\begin{array}{l}\text { 1.011-NSR- } \\
\text { Value- } \\
\text { Dependent }\end{array}$ & $\begin{array}{l}\text { IfThenElseResult } \\
( \\
\operatorname{Not}(\operatorname{Present}(\operatorname{Rec}(4))) \text {, } \\
\mathrm{EQ}(\{\operatorname{Fld}(1.011)\}, \operatorname{Num}(00.00)) \text {, } \\
\text { IfThenElseResult } \\
( \\
\text { GTE(NV(\{Fld(1.011)\}), Num(38.58)), } \\
\text { ReturnResult }\end{array}$ & $\mathrm{t} 11$ & M-Fld(1.011) & $\begin{array}{l}\text { REMOVE } \\
\text { NIEM } \\
\text { ASSERTIO } \\
\text { N BELOW }\end{array}$ & & & B \\
\hline
\end{tabular}




\begin{tabular}{|c|c|c|c|c|c|c|c|c|c|c|c|}
\hline Req. \# - ID & $\begin{array}{l}\text { Ref. in } \\
\text { Base } \\
\text { Std. }\end{array}$ & $\begin{array}{l}\text { Requirement } \\
\text { Summary }\end{array}$ & $\begin{array}{l}\text { L } \\
\text { e } \\
\text { v } \\
\text { e } \\
\text { l }\end{array}$ & $\begin{array}{l}\text { Assertion } \\
\text { ID }\end{array}$ & $\begin{array}{c}\text { Test } \\
\text { Assertion }\end{array}$ & $\begin{array}{l}\mathbf{N} \\
\mathbf{o} \\
\mathbf{t} \\
\mathbf{e} \\
\mathbf{S}\end{array}$ & $\begin{array}{l}\text { Imp. } \\
\text { Required }\end{array}$ & $\begin{array}{l}\text { Imp. } \\
\text { Support }\end{array}$ & $\begin{array}{l}\text { Supporte } \\
\text { d Range }\end{array}$ & $\begin{array}{c}\text { Test } \\
\text { Result }\end{array}$ & $\begin{array}{l}\mathbf{E} \\
\mathbf{n} \\
\mathbf{c} \\
\text {. }\end{array}$ \\
\hline \multicolumn{12}{|c|}{ Record Type-1: Transaction information record } \\
\hline & & $\begin{array}{l}\text { records at } 1000 \text { ppi class or greater. } \\
\text { NSR contains five characters specifying } \\
\text { the native scanning resolution in pixels per } \\
\text { millimeter. It is expressed as two numeric } \\
\text { characters followed by a decimal point and } \\
\text { two more numeric characters (e.g. 19.69). } \\
\text { Exemplar images shall have a minimum } \\
\text { scanning resolution of the } 500 \text { ppi class. } \\
\text { In this version, NSR and NTR only apply } \\
\text { to Record Type-4: Grayscale fingerprint } \\
\text { image... } \\
\text { Table } 14 \text { defines resolution tolerance for } \\
\text { fingerprint types. } 2 \% \text { is used as the default; } \\
\text { see test note t-11 for details. } \\
\text { Note: the minimum value with tolerance } \\
\text { was } 19.30 \text { in } 2011 \text {. This is changed to } \\
19.29 \text { in } 2013 \text { due to the rounding method } \\
\text { mentioned in } 7.7 .8 .4 \text {. }\end{array}$ & & & $\begin{array}{l}\text { Result(Warning(Images with scanning resolution } \\
\text { equal to or greater than the } 1000 \text { ppi class should } \\
\text { not be transmitted using Record Type-4 unless } \\
\text { they are scaled-down to produce a transmitting } \\
\text { resolution of class 500ppi.)) } \\
\text { ), } \\
\text { GTE(NV(\{Fld(1.011)\}), Num(19.29)), } \\
)\end{array}$ & & & & & & \\
\hline $\begin{array}{l}\text { RT1.56 - Fie } \\
\text { ld: } 1.011- \\
\text { NSR- } \\
\text { CharType }\end{array}$ & $\begin{array}{c}8.1 \\
\text { Table 22, }\end{array}$ & $\begin{array}{l}\text { Section } 8.1 \text { and Table } 22 \text { specify the } \\
\text { Character Type for each field. } \\
\text { Numeric values shall not contain leading } \\
\text { zeros unless indicated by the standard text. } \\
\text { Leading zeros are allowed for } 1.002,1.011 \text {, } \\
1.012,99.100 \text {, and } 99.101 \text {. Any dates may } \\
\text { also contain leading zeros. }\end{array}$ & 1 & $\begin{array}{l}\text { 1.011-NSR- } \\
\text { CharType }\end{array}$ & $\begin{array}{l}\text { SubSet } \\
( \\
\text { Chars(\{Fld(1.011)\}), } \\
\text { Union(CharNum, Set-Str([.])) } \\
\text { ) }\end{array}$ & & M-Fld(1.011) & & & & B \\
\hline \multirow[t]{2}{*}{$\begin{array}{l}\text { RT1.57 - Fie } \\
\text { Id: 1.011- } \\
\text { NSR- } \\
\text { CharCount }\end{array}$} & \multirow[t]{2}{*}{ Table 22} & \multirow[t]{2}{*}{$\begin{array}{l}\text { Table } 22 \text { specifies the character count for } \\
\text { each field. }\end{array}$} & 1 & $\begin{array}{l}\text { 1.011-NSR- } \\
\text { CharCount }\end{array}$ & $\begin{array}{l}\text { EQ } \\
( \\
\operatorname{Count}(\operatorname{Chars}(\{\operatorname{Fld}(1.011)\})), \\
\operatorname{Int}(5)\end{array}$ & & M-Fld(1.011) & & & & $\mathrm{T}$ \\
\hline & & & 1 & $\begin{array}{l}\text { NIEM- } \\
\text { 1.011-NSR- } \\
\text { CharCount }\end{array}$ & $\begin{array}{l}\text { MO } \\
( \\
\text { Count }(\operatorname{Chars}(\{\operatorname{Fld}(1.011)\})) \text {, } \\
\text { Set-Int }([4,5])\end{array}$ & & M-Fld(1.011) & & & & $\mathrm{X}$ \\
\hline
\end{tabular}




\begin{tabular}{|c|c|c|c|c|c|c|c|c|c|c|c|}
\hline Req. \# - ID & $\begin{array}{l}\text { Ref. in } \\
\text { Base } \\
\text { Std. }\end{array}$ & $\begin{array}{c}\text { Requirement } \\
\text { Summary }\end{array}$ & $\begin{array}{l}\text { L } \\
\text { e } \\
\text { v } \\
\text { e } \\
\text { l }\end{array}$ & $\begin{array}{l}\text { Assertion } \\
\text { ID }\end{array}$ & $\begin{array}{c}\text { Test } \\
\text { Assertion }\end{array}$ & $\begin{array}{l}\mathbf{N} \\
\mathbf{o} \\
\mathbf{t} \\
\mathbf{e} \\
\mathbf{S}\end{array}$ & $\begin{array}{c}\text { Imp. } \\
\text { Required }\end{array}$ & $\begin{array}{c}\text { Imp. } \\
\text { Support }\end{array}$ & $\begin{array}{l}\text { Supporte } \\
\text { d Range }\end{array}$ & $\begin{array}{c}\text { Test } \\
\text { Result }\end{array}$ & \\
\hline \multicolumn{12}{|c|}{ Record Type-1: Transaction information record } \\
\hline & & & & & ) & & & & & & \\
\hline \multirow[t]{2}{*}{$\begin{array}{l}\text { RT1.58 - Fie } \\
\text { Id: } 1.012- \\
\text { NTR- } \\
\text { FieldStructu } \\
\quad \text { re }\end{array}$} & \multirow[t]{2}{*}{$\begin{array}{l}\text { Table 22, } \\
\text { Annex B, } \\
\text { Annex G }\end{array}$} & \multirow{2}{*}{$\begin{array}{l}\text { Table } 22 \text { specifies which fields contain } \\
\text { subfields and information items as well as } \\
\text { the number of occurrences permitted. } \\
\text { A field contains a minimum of one } \\
\text { subfield which contains a minimum of one } \\
\text { information item. }\end{array}$} & 1 & $\begin{array}{c}\text { 1.012-NTR- } \\
\text { SubfieldCou } \\
\text { nt }\end{array}$ & $\begin{array}{l}\text { EQ } \\
( \\
\text { Count(SubFldsIn(Fld(1.012))), } \\
\operatorname{Int}(1)\end{array}$ & & M-Fld(1.012) & & & & $\mathrm{T}$ \\
\hline & & & 1 & $\begin{array}{c}\text { 1.012-NTR- } \\
\text { InfoItemCou } \\
\mathrm{nt}\end{array}$ & $\begin{array}{l}\text { EQ } \\
( \\
\text { Count(InfoItemsIn(SubFld(1.012.1))), } \\
\operatorname{Int}(1)\end{array}$ & & M-Fld(1.012) & & & & $\mathrm{T}$ \\
\hline \multirow[t]{4}{*}{$\begin{array}{c}\text { RT1.59 - Fie } \\
\text { Id: 1.012- } \\
\text { NTR-Value }\end{array}$} & \multirow[t]{4}{*}{$\begin{array}{l}\text { 8.1.12, } \\
\text { Table } 22, \\
7.7 .6 \\
7.7 .6 .3 .1\end{array}$} & \multirow{4}{*}{$\begin{array}{l}\text { This mandatory field shall be set to } \\
\text { " } 00.00 \text { " if there are no Type- } 4 \text { records in } \\
\text { the transaction. } \\
\text { When there are Type- } 4 \text { records present, } \\
\text { this field specifies the nominal resolution } \\
\text { for the image(s) being exchanged. This } \\
\text { field shall specify the resolution in pixels } \\
\text { per millimeter. } \\
\text { The resolution shall be within the range } \\
19.30 \text { ppmm ( } 490 \text { ppi) to } 20.08 \text { ppmm ( } 510 \\
\text { ppi). }\end{array}$} & 1 & $\begin{array}{l}\text { 1.012-NTR- } \\
\text { Value }\end{array}$ & $\begin{array}{l}\operatorname{RegEx} \\
\{\operatorname{Fld}(1.012)\} \\
\operatorname{Str}(\wedge[0-9]\{2\} \backslash .[0-9]\{2\} \$)\end{array}$ & & M-Fld(1.012) & & & & $\mathrm{T}$ \\
\hline & & & 1 & $\begin{array}{l}\text { NIEM- } \\
\text { 1.012-NTR- } \\
\text { Value }\end{array}$ & $\begin{array}{l}\operatorname{RegEx} \\
( \\
\{\operatorname{Fld}(1.012)\}, \\
\operatorname{Str}(\wedge[0-9]\{1,2\} \backslash[0-9]\{2\} \$)\end{array}$ & & M-Fld(1.012) & & & & $\mathrm{X}$ \\
\hline & & & 2 & $\begin{array}{c}1.012- \\
\text { Value- } \\
\text { Dependent }\end{array}$ & $\begin{array}{l}\text { IfThenElse } \\
( \\
\text { Present(Rec(4)), } \\
\text { InRange } \\
( \\
\mathrm{NV}(\{\operatorname{Fld}(1.012)\}), \operatorname{Num}(19.29), \operatorname{Num}(20.08) \\
), \\
\mathrm{EQ}(\{\operatorname{Fld}(1.012)\}, \operatorname{Num}(00.00)) \\
)\end{array}$ & $\mathrm{t} 11$ & M-Fld(1.012) & $\begin{array}{l}\text { REMOVE } \\
\text { NIEM } \\
\text { ASSERT } \\
\text { BELOW }\end{array}$ & & & B \\
\hline & & & 2 & $\begin{array}{l}\text { 1.012-NTR- } \\
\text { Value- } \\
\text { Dependent- } \\
\text { LTE-1.011 }\end{array}$ & $\begin{array}{l}\text { LTE } \\
\{\text { Fld }(1.012)\} \\
\{\operatorname{Fld}(1.011)\}\end{array}$ & & M-Fld(1.012) & & & & B \\
\hline $\begin{array}{l}\text { RT1.60 - Fie } \\
\text { ld: } 1.012- \\
\text { NTR- } \\
\text { CharType }\end{array}$ & $\begin{array}{c}8.1 \\
\text { Table 22, }\end{array}$ & $\begin{array}{l}\text { Section } 8.1 \text { and Table } 22 \text { specify the } \\
\text { Character Type for each field. } \\
\text { Numeric values shall not contain leading } \\
\text { zeros unless indicated by the standard text. } \\
\text { Leading zeros are allowed for } 1.002,1.011 \text {, } \\
1.012,99.100 \text {, and } 99.101 \text {. Any dates may }\end{array}$ & 1 & $\begin{array}{l}\text { 1.012-NTR- } \\
\text { CharType }\end{array}$ & $\begin{array}{l}\text { SubSet } \\
( \\
\text { Chars(\{Fld(1.012)\}), } \\
\text { Union(CharNum, Set-Str([.])) } \\
\text { ) }\end{array}$ & & M-Fld(1.012) & & & & B \\
\hline
\end{tabular}




\begin{tabular}{|c|c|c|c|c|c|c|c|c|c|c|c|}
\hline Req. \# - ID & $\begin{array}{l}\text { Ref. in } \\
\text { Base } \\
\text { Std. }\end{array}$ & $\begin{array}{l}\text { Requirement } \\
\text { Summary }\end{array}$ & $\begin{array}{l}\text { L } \\
\text { e } \\
\text { v } \\
\text { e } \\
\text { l }\end{array}$ & $\begin{array}{l}\text { Assertion } \\
\text { ID }\end{array}$ & $\begin{array}{c}\text { Test } \\
\text { Assertion }\end{array}$ & $\begin{array}{l}\mathbf{N} \\
\mathbf{o} \\
\mathbf{t} \\
\mathbf{e} \\
\mathbf{S}\end{array}$ & $\begin{array}{c}\text { Imp. } \\
\text { Required }\end{array}$ & $\begin{array}{c}\text { Imp. } \\
\text { Support }\end{array}$ & $\begin{array}{l}\text { Supporte } \\
\text { d Range }\end{array}$ & $\begin{array}{c}\text { Test } \\
\text { Result }\end{array}$ & $\begin{array}{l}\mathbf{E} \\
\mathbf{n} \\
\mathbf{c} \\
\text {. }\end{array}$ \\
\hline \multicolumn{12}{|c|}{ Record Type-1: Transaction information record } \\
\hline & & also contain leading zeros. & & & & & & & & & \\
\hline \multirow[t]{2}{*}{$\begin{array}{l}\text { RT1.61 - Fie } \\
\text { ld: } 1.012- \\
\text { NTR- } \\
\text { CharCount }\end{array}$} & \multirow[t]{2}{*}{ Table 22} & \multirow[t]{2}{*}{$\begin{array}{l}\text { Table } 22 \text { specifies the character count for } \\
\text { each field. }\end{array}$} & 1 & $\begin{array}{l}\text { 1.012-NTR- } \\
\text { CharCount }\end{array}$ & $\begin{array}{l}\text { EQ } \\
( \\
\operatorname{Count}(\operatorname{Chars}(\{\operatorname{Fld}(1.012)\})) \text {, } \\
\operatorname{Int}(5)\end{array}$ & & M-Fld(1.012) & & & & $\mathrm{T}$ \\
\hline & & & 1 & $\begin{array}{l}\text { NIEM- } \\
\text { 1.012-NTR- } \\
\text { CharCount }\end{array}$ & $\begin{array}{l}\text { MO } \\
( \\
\text { Count }(\operatorname{Chars}(\{\operatorname{Fld}(1.012)\})) \text {, } \\
\text { Set-Int }([4,5])\end{array}$ & & M-Fld(1.012) & & & & $\mathrm{X}$ \\
\hline \multirow[t]{3}{*}{$\begin{array}{l}\text { RT1.62 - Fie } \\
\text { Id: } 1.013- \\
\text { DOM- } \\
\text { FieldStructu } \\
\quad \text { re }\end{array}$} & \multirow[t]{3}{*}{$\begin{array}{l}\text { Table 22, } \\
\text { Annex B, } \\
\text { Annex G }\end{array}$} & \multirow{3}{*}{$\begin{array}{l}\text { Table } 22 \text { specifies which fields contain } \\
\text { subfields and information items as well as } \\
\text { the number of occurrences permitted. } \\
\text { A field contains a minimum of one } \\
\text { subfield which contains a minimum of one } \\
\text { information item. }\end{array}$} & 1 & $\begin{array}{c}\text { 1.013-DOM- } \\
\text { SubfieldCou } \\
\mathrm{nt}\end{array}$ & $\begin{array}{l}\text { EQ } \\
\text { Count(SubFldsIn(Fld(1.013))), } \\
\operatorname{Int}(1)\end{array}$ & & O-Fld(1.013) & & & & $\mathrm{T}$ \\
\hline & & & 1 & $\begin{array}{c}\text { 1.013-DOM- } \\
\text { InfoItemCou } \\
\mathrm{nt}\end{array}$ & $\begin{array}{l}\text { EQ } \\
( \\
\text { Count }(\operatorname{InfoItemsIn}(\operatorname{SubFld}(1.013 .1))) \text {, } \\
\text { Int(2) }\end{array}$ & & O-Fld(1.013) & & & & $\mathrm{T}$ \\
\hline & & & 1 & $\begin{array}{l}\text { 1.013-DOM- } \\
\text { InfoItemStru } \\
\text { cture }\end{array}$ & $\begin{array}{l}\text { InfoItemsHaveData } \\
( \\
\text { SubFld(1.013.1), } \\
\text { Set-Int([1]) } \\
\text { ) }\end{array}$ & & O-Fld(1.013) & & & & $\mathrm{T}$ \\
\hline $\begin{array}{l}\text { RT1.63 - Fie } \\
\text { Id: 1.013- } \\
\text { DNM-Value }\end{array}$ & $\begin{array}{l}8.1 .13 \\
\text { Table } 22\end{array}$ & $\begin{array}{l}\text { The mandatory first information item } \\
\text { (domain name / DNM) will uniquely } \\
\text { identify the agency, entity, or } \\
\text { implementation used for formatting the } \\
\text { fields in the Type- } 2 \text { record. The default } \\
\text { value for the field shall be the North } \\
\text { American Domain implementation } \\
\text { (NORAM). }\end{array}$ & 1 & $\begin{array}{l}\text { 1.013-DNM- } \\
\text { Value }\end{array}$ & $\begin{array}{l}\text { ReturnResult } \\
( \\
\text { Result(Pass) } \\
\text { ) }\end{array}$ & & $\begin{array}{c}\mathrm{M} \uparrow- \\
\text { InfoI(1.013.D } \\
\mathrm{NM})\end{array}$ & & & & B \\
\hline $\begin{array}{l}\text { RT1.64 - Fie } \\
\text { ld: 1.013- } \\
\text { DNM- } \\
\text { CharType }\end{array}$ & $\begin{array}{c}8.1 \\
\text { Table 22, }\end{array}$ & $\begin{array}{l}\text { Section } 8.1 \text { and Table } 22 \text { specify the } \\
\text { Character Type for each field. }\end{array}$ & 1 & $\begin{array}{l}\text { 1.013-DNM- } \\
\text { CharType }\end{array}$ & $\begin{array}{l}\text { SubSet } \\
(\text { Chars( }\{\text { InfoI(1.013.DNM })\}), \\
\text { CharsAsciiPrintable } \\
\text { ) }\end{array}$ & & $\begin{array}{c}\mathrm{M} \uparrow- \\
\text { InfoI(1.013.D } \\
\mathrm{NM})\end{array}$ & & & & B \\
\hline RT1.65 - Fie & Table 22 & Table 22 specifies the character count for & 1 & 1.013-DNM- & GTE & & $\mathrm{M} \uparrow-$ & & & & $\mathrm{B}$ \\
\hline
\end{tabular}




\begin{tabular}{|c|c|c|c|c|c|c|c|c|c|c|c|}
\hline Req. \# - ID & $\begin{array}{l}\text { Ref. in } \\
\text { Base } \\
\text { Std. }\end{array}$ & $\begin{array}{l}\text { Requirement } \\
\text { Summary }\end{array}$ & $\begin{array}{l}\text { L } \\
\text { e } \\
\text { v } \\
\text { e } \\
\text { l }\end{array}$ & $\begin{array}{l}\text { Assertion } \\
\text { ID }\end{array}$ & $\begin{array}{c}\text { Test } \\
\text { Assertion }\end{array}$ & $\begin{array}{l}\mathbf{N} \\
\mathbf{o} \\
\mathbf{t} \\
\mathbf{e} \\
\mathbf{S}\end{array}$ & $\begin{array}{c}\text { Imp. } \\
\text { Required }\end{array}$ & $\begin{array}{c}\text { Imp. } \\
\text { Support }\end{array}$ & $\begin{array}{l}\text { Supporte } \\
\text { d Range }\end{array}$ & $\begin{array}{c}\text { Test } \\
\text { Result }\end{array}$ & $\begin{array}{l}\mathbf{E} \\
\mathbf{n} \\
\mathbf{c} \\
\text {. }\end{array}$ \\
\hline \multicolumn{12}{|c|}{ Record Type-1: Transaction information record } \\
\hline $\begin{array}{l}\text { Id: 1.013- } \\
\text { DNM- } \\
\text { CharCount }\end{array}$ & & each field. & & CharCount & $\begin{array}{l}\text { Count(Chars(\{InfoI(1.013.DNM })\}) \text {, } \\
\operatorname{Int}(1)\end{array}$ & & $\begin{array}{l}\text { InfoI(1.013.D } \\
\text { NM) }\end{array}$ & & & & \\
\hline $\begin{array}{c}\text { RT1.66 - Fie } \\
\text { Id: 1.013- } \\
\text { DVN-Value }\end{array}$ & $\begin{array}{l}\text { 8.1.13, } \\
\text { Table } 22\end{array}$ & $\begin{array}{l}\text { An optional second information item } \\
\text { (domain version number / DVN) shall } \\
\text { contain the unique version of the particular } \\
\text { implementation, such as } 7.02 \text {. }\end{array}$ & 1 & $\begin{array}{l}\text { 1.013-DVN- } \\
\text { Value }\end{array}$ & $\begin{array}{l}\text { ReturnResult } \\
( \\
\text { Result(Pass) } \\
\text { ) }\end{array}$ & & $\begin{array}{l}\mathrm{O} \uparrow- \\
\text { InfoI }(1.013 . \mathrm{D} \\
\mathrm{VN})\end{array}$ & & & & B \\
\hline $\begin{array}{l}\text { RT1.67 - Fie } \\
\text { Id: } 1.013- \\
\text { DVN- } \\
\text { CharType }\end{array}$ & $\begin{array}{c}8.1 \\
\text { Table } 22,\end{array}$ & $\begin{array}{l}\text { Section } 8.1 \text { and Table } 22 \text { specify the } \\
\text { Character Type for each field. }\end{array}$ & 1 & $\begin{array}{l}\text { 1.013-DVN- } \\
\text { CharType }\end{array}$ & $\begin{array}{l}\text { SubSet } \\
( \\
\text { Chars }(\{\text { InfoI }(1.013 . D V N)\}), \\
\text { CharsAsciiPrintable } \\
\text { ) }\end{array}$ & & $\begin{array}{c}\mathrm{O} \uparrow- \\
\text { InfoI(1.013.D } \\
\text { VN) }\end{array}$ & & & & B \\
\hline $\begin{array}{l}\text { RT1.68 - Fie } \\
\text { Id: } 1.013- \\
\text { DVN- } \\
\text { CharCount }\end{array}$ & Table 22 & $\begin{array}{l}\text { Table } 22 \text { specifies the character count for } \\
\text { each field. }\end{array}$ & 1 & $\begin{array}{l}\text { 1.013-DVN- } \\
\text { CharCount }\end{array}$ & $\begin{array}{l}\text { GTE } \\
( \\
\text { Count }(\operatorname{Chars}(\{\operatorname{InfoI}(1.013 . D V N)\}), \\
\text { Int(1) }\end{array}$ & & $\begin{array}{l}\mathrm{O} \uparrow- \\
\text { InfoI }(1.013 . \mathrm{D} \\
\mathrm{VN})\end{array}$ & & & & B \\
\hline \multirow[t]{2}{*}{$\begin{array}{l}\text { RT1.69 - Fie } \\
\text { Id: } 1.014- \\
\text { GMT- } \\
\text { FieldStructu } \\
\quad \text { re }\end{array}$} & \multirow[t]{2}{*}{$\begin{array}{l}\text { Table 22, } \\
\text { Annex B, } \\
\text { Annex G }\end{array}$} & \multirow{2}{*}{$\begin{array}{l}\text { Table } 22 \text { specifies which fields contain } \\
\text { subfields and information items as well as } \\
\text { the number of occurrences permitted. } \\
\text { A field contains a minimum of one } \\
\text { subfield which contains a minimum of one } \\
\text { information item. }\end{array}$} & 1 & $\begin{array}{l}\text { 1.014-GMT- } \\
\text { SubfieldCou } \\
\text { nt }\end{array}$ & $\begin{array}{l}\text { EQ } \\
(\text { Count(SubFldsIn(Fld(1.014))), } \\
\text { Int(1) }\end{array}$ & & O-Fld(1.014) & & & & $\mathrm{T}$ \\
\hline & & & 1 & $\begin{array}{l}\text { 1.014-GMT- } \\
\text { InfoItemCou } \\
\text { nt }\end{array}$ & $\begin{array}{l}\text { EQ } \\
( \\
\text { Count(InfoItemsIn(SubFld(1.014.1))), } \\
\text { Int(1) }\end{array}$ & & O-Fld(1.014) & & & & $\mathrm{T}$ \\
\hline \multirow[t]{2}{*}{$\begin{array}{l}\text { RT1.70 - Fie } \\
\text { ld: } 1.014- \\
\text { GMT-Value }\end{array}$} & \multirow[t]{2}{*}{$\begin{array}{l}\text { 8.1.14, } \\
\text { Table } 22\end{array}$} & \multirow[t]{2}{*}{$\begin{array}{l}\text { This optional field provides a mechanism } \\
\text { for expressing the date and time in terms of } \\
\text { universal Greenwich Mean Time (GMT) } \\
\text { units. }\end{array}$} & 1 & $\begin{array}{l}\text { 1.014-GMT- } \\
\text { Value }\end{array}$ & $\begin{array}{l}\text { Complex } \\
\text { EQ } \\
( \\
\{\text { Fld(1.014)\}, } \\
\text { ValidUTC/GMT } \\
) \text { ) }\end{array}$ & $\mathrm{t} 3$ & O-Fld(1.014) & & & & $\mathrm{T}$ \\
\hline & & & 1 & $\begin{array}{l}\text { NIEM- } \\
\text { 1.014-GMT- } \\
\text { Value }\end{array}$ & $\begin{array}{l}\text { Complex } \\
\text { EQ } \\
\{\text { XElm(1.014.nc:DateTime) }\} \text {, } \\
\text { NIEM-ValidUTC/GMT } \\
\text { )) }\end{array}$ & $\mathrm{t} 3$ & O-Fld(1.014) & & & & $\mathrm{X}$ \\
\hline RT1.71 - Fie & 8.1 & Section 8.1 and Table 22 specify the & 1 & 1.014-GMT- & SubSet & & O-Fld(1.014) & & & & B \\
\hline
\end{tabular}




\begin{tabular}{|c|c|c|c|c|c|c|c|c|c|c|c|}
\hline Req. \# - ID & $\begin{array}{l}\text { Ref. in } \\
\text { Base } \\
\text { Std. }\end{array}$ & $\begin{array}{l}\text { Requirement } \\
\text { Summary }\end{array}$ & $\begin{array}{l}\text { L } \\
\text { e } \\
\text { v } \\
\text { e } \\
\text { l }\end{array}$ & $\begin{array}{l}\text { Assertion } \\
\text { ID }\end{array}$ & $\begin{array}{c}\text { Test } \\
\text { Assertion }\end{array}$ & $\begin{array}{l}\mathbf{N} \\
\mathbf{o} \\
\mathbf{t} \\
\mathrm{e} \\
\mathrm{S}\end{array}$ & $\begin{array}{l}\text { Imp. } \\
\text { Required }\end{array}$ & $\begin{array}{l}\text { Imp. } \\
\text { Support }\end{array}$ & $\begin{array}{l}\text { Supporte } \\
\text { d Range }\end{array}$ & $\begin{array}{c}\text { Test } \\
\text { Result }\end{array}$ & $\begin{array}{l}\mathbf{E} \\
\mathbf{n} \\
\mathbf{c} \\
\text {. }\end{array}$ \\
\hline \multicolumn{12}{|c|}{ Record Type-1: Transaction information record } \\
\hline \multirow[t]{2}{*}{$\begin{array}{l}\text { Id: 1.014- } \\
\text { GMT- } \\
\text { CharType }\end{array}$} & \multirow[t]{2}{*}{ Table 22, } & \multirow{2}{*}{$\begin{array}{l}\text { Character Type for each field. } \\
\text { Numeric values shall not contain leading } \\
\text { zeros unless indicated by the standard text. } \\
\text { Leading zeros are allowed for } 1.002,1.011 \text {, } \\
1.012,99.100 \text {, and } 99.101 \text {. Any dates may } \\
\text { also contain leading zeros. }\end{array}$} & & CharType & $\begin{array}{l}\text { Chars(\{Fld(1.014)\}), } \\
\text { Union(CharNum, Set-Str([Z])) } \\
\text { ) }\end{array}$ & & & & & & \\
\hline & & & 1 & $\begin{array}{l}\text { NIEM- } \\
\text { 1.014-GMT- } \\
\text { CharType }\end{array}$ & $\begin{array}{l}\text { SubSet } \\
( \\
\text { Chars(\{Fld(1.014)\}), } \\
\text { Union(CharNum, Set-Str([-,:,T,Z])) } \\
\text { ) }\end{array}$ & & O-Fld(1.014) & & & & B \\
\hline \multirow[t]{2}{*}{$\begin{array}{l}\text { RT1.72 - Fie } \\
\text { Id: 1.014- } \\
\text { GMT- } \\
\text { CharCount }\end{array}$} & \multirow[t]{2}{*}{ Table 22} & \multirow[t]{2}{*}{$\begin{array}{l}\text { Table } 22 \text { specifies the character count for } \\
\text { each field. }\end{array}$} & 1 & $\begin{array}{l}\text { 1.014-GMT- } \\
\text { CharCount }\end{array}$ & $\begin{array}{l}\text { EQ } \\
\text { Count(Chars }(\{\operatorname{Fld}(1.014)\}) \\
\operatorname{Int}(15)\end{array}$ & & O-Fld(1.014) & & & & $\mathrm{T}$ \\
\hline & & & 1 & $\begin{array}{l}\text { NIEM- } \\
\text { 1.014-GMT- } \\
\text { CharCount }\end{array}$ & $\begin{array}{l}\text { EQ } \\
( \\
\operatorname{Count}(\operatorname{Chars}(\{\operatorname{Fld}(1.014)\}), \\
\operatorname{Int}(20)\end{array}$ & & O-Fld(1.014) & & & & $\mathrm{X}$ \\
\hline \multirow[t]{3}{*}{$\begin{array}{l}\text { RT1.73 - Fie } \\
\text { ld: } 1.015- \\
\text { DCS- } \\
\text { FieldStructu } \\
\text { re }\end{array}$} & \multirow[t]{3}{*}{$\begin{array}{l}\text { Table 22, } \\
\text { Annex B, } \\
\text { Annex G }\end{array}$} & \multirow{3}{*}{$\begin{array}{l}\text { Table } 22 \text { specifies which fields contain } \\
\text { subfields and information items as well as } \\
\text { the number of occurrences permitted. } \\
\text { A field contains a minimum of one } \\
\text { subfield which contains a minimum of one } \\
\text { information item. }\end{array}$} & 1 & $\begin{array}{l}\text { 1.015-DCS- } \\
\text { SubfieldCou } \\
\text { nt }\end{array}$ & $\begin{array}{l}\text { EQ } \\
\text { Count(SubFldsIn(Fld(1.015))), } \\
\text { Int(1) }\end{array}$ & & O-Fld(1.015) & & & & $\mathrm{T}$ \\
\hline & & & 1 & $\begin{array}{l}\text { 1.015-DCS- } \\
\text { InfoItemCou } \\
\mathrm{nt}\end{array}$ & $\begin{array}{l}\text { EQ } \\
( \\
\text { Count (InfoItemsIn(SubFld(1.015.1))), } \\
\text { Int }(2,3)\end{array}$ & & O-Fld(1.015) & & & & $\mathrm{T}$ \\
\hline & & & 1 & $\begin{array}{l}\text { 1.015-DCS- } \\
\text { InfoItemStru } \\
\text { cture }\end{array}$ & $\begin{array}{l}\text { InfoItemsHaveData } \\
\text { SubFld(1.015.1), } \\
\text { Set-Int([1,2]) }\end{array}$ & & O-Fld(1.015) & & & & $\mathrm{T}$ \\
\hline $\begin{array}{l}\text { RT1.74 - Fie } \\
\text { Id: } 1.015- \\
\text { CSI-Value }\end{array}$ & $\begin{array}{l}8.1 .15, \\
\text { Table } 22, \\
\text { Table } 4, \\
5.4,5.6\end{array}$ & $\begin{array}{l}\text { The first information item (character } \\
\text { encoding index / CSI) is the index number } \\
\text { that references an associated character } \\
\text { encoding. See the "Character encoding } \\
\text { index" column of Table } 4 \text { for the valid } \\
\text { values for this information item. }\end{array}$ & 1 & $\begin{array}{l}\text { 1.015-CSI- } \\
\text { Value }\end{array}$ & $\begin{array}{l}\text { IfThenElseResult } \\
\text { ( } \\
\text { MO(NV }\{\text { InfoI(1.015.CSI) }\} \text {, Set-Int([0, } 2 \text { to } 4 \text {, } \\
\text { Result(Pass), } \\
\text { IfThenElseResult } \\
\text { ( }\end{array}$ & & $\begin{array}{l}\mathrm{M} \uparrow- \\
\text { InfoI }(1.015 . \mathrm{C} \\
\mathrm{SI})\end{array}$ & & & & B \\
\hline
\end{tabular}




\begin{tabular}{|c|c|c|c|c|c|c|c|c|c|c|c|}
\hline Req. \# - ID & $\begin{array}{l}\text { Ref. in } \\
\text { Base } \\
\text { Std. }\end{array}$ & $\begin{array}{l}\text { Requirement } \\
\text { Summary }\end{array}$ & $\begin{array}{l}\text { L } \\
\text { e } \\
\text { v } \\
\text { e } \\
\text { l }\end{array}$ & $\begin{array}{l}\text { Assertion } \\
\text { ID }\end{array}$ & $\begin{array}{c}\text { Test } \\
\text { Assertion }\end{array}$ & $\begin{array}{l}\mathbf{N} \\
\mathbf{o} \\
\mathbf{t} \\
\mathrm{e} \\
\mathbf{S}\end{array}$ & $\begin{array}{c}\text { Imp. } \\
\text { Required }\end{array}$ & $\begin{array}{l}\text { Imp. } \\
\text { Support }\end{array}$ & $\begin{array}{l}\text { Supporte } \\
\text { d Range }\end{array}$ & $\begin{array}{c}\text { Test } \\
\text { Result }\end{array}$ & $\begin{array}{l}\mathbf{E} \\
\mathbf{n} \\
\mathbf{c} \\
\text {. }\end{array}$ \\
\hline \multicolumn{12}{|c|}{ Record Type-1: Transaction information record } \\
\hline & & $\begin{array}{l}\text { 'Legacy' indicates that if there is existing } \\
\text { data using this record type, field, } \\
\text { information item or value it may still be } \\
\text { transmitted in a transaction conformant to } \\
\text { this version of the standard. In this version } \\
\text { 'legacy' applies to Fields } 9.005 \text { through } \\
9.012 \text {, Field } 10.022 \text { and to the value ' } 1 \text { ' in } \\
\text { Table } 4 \text { Character encoding. } \\
\text { Note that the value " } 1 \text { " does not appear in } \\
\text { the table. It is a legacy value. }\end{array}$ & & & $\begin{array}{l}\mathrm{EQ}(\{\operatorname{InfoI}(1.015 . \mathrm{CSI})\}, \operatorname{Str}(1)) \text {, } \\
\text { Result(Warning('1' is a Legacy value. })) \text {, } \\
\text { Result(Fail) } \\
)^{\prime}\end{array}$ & & & & & & \\
\hline \multirow[t]{2}{*}{$\begin{array}{l}\text { RT1.75 - Fie } \\
\text { ld: } 1.015- \\
\text { CSI- } \\
\text { CharType }\end{array}$} & \multirow[t]{2}{*}{$\begin{array}{c}8.1 \\
\text { Table 22, }\end{array}$} & \multirow{2}{*}{$\begin{array}{l}\text { Section } 8.1 \text { and Table } 22 \text { specify the } \\
\text { Character Type for each field. } \\
\text { Numeric values shall not contain leading } \\
\text { zeros unless indicated by the standard text. } \\
\text { Leading zeros are allowed for } 1.002,1.011 \text {, } \\
1.012,99.100 \text {, and } 99.101 \text {. Any dates may } \\
\text { also contain leading zeros. }\end{array}$} & 1 & $\begin{array}{l}\text { 1.015-CSI- } \\
\text { CharType }\end{array}$ & $\begin{array}{l}\text { SubSet } \\
( \\
\text { Chars( }\{\text { InfoI }(1.015 . \mathrm{CSI})\}), \\
\text { CharNum } \\
\text { ) }\end{array}$ & & $\begin{array}{l}\mathrm{M} \uparrow- \\
\text { InfoI }(1.015 . \mathrm{C} \\
\mathrm{SI})\end{array}$ & & & & B \\
\hline & & & 1 & $\begin{array}{l}\text { 1.015-CSI- } \\
\text { NoLeadingZ } \\
\text { eros }\end{array}$ & $\begin{array}{l}\text { NOT } \\
( \\
\text { RegEx } \\
(\text { InfoI(1.015.CSI) }\} \\
\text { LeadingZeroNum } \\
) \\
)\end{array}$ & & $\begin{array}{l}\mathrm{M} \uparrow- \\
\text { InfoI }(1.015 . \mathrm{C} \\
\mathrm{SI})\end{array}$ & & & & B \\
\hline $\begin{array}{l}\text { RT1.76 - Fie } \\
\text { Id: } 1.015- \\
\text { CSI- } \\
\text { CharType }\end{array}$ & Table 22 & $\begin{array}{l}\text { Table } 22 \text { specifies the character count for } \\
\text { each field. }\end{array}$ & 1 & $\begin{array}{l}1.015 \text {-CSI- } \\
\text { CharCount }\end{array}$ & $\begin{array}{l}\text { MO } \\
( \\
\text { Count }(\operatorname{Chars}(\{\operatorname{InfoI}(1.015 . \mathrm{CSI})\}), \\
\text { Set-Int }([1,2,3]) \\
)\end{array}$ & & $\begin{array}{l}\mathrm{M} \uparrow- \\
\text { InfoI }(1.015 . \mathrm{C} \\
\mathrm{SI})\end{array}$ & & & & B \\
\hline \multirow[t]{2}{*}{$\begin{array}{l}\text { RT1.77 - Fie } \\
\text { Id: } 1.015- \\
\text { CSN-Value }\end{array}$} & \multirow[t]{2}{*}{$\begin{array}{l}8.1 .15, \\
\text { Table } 22, \\
\text { Table } 4\end{array}$} & \multirow{2}{*}{$\begin{array}{l}\text { The second information item (character } \\
\text { encoding name / CSN) shall be the } \\
\text { "Character encoding name" associated } \\
\text { with that index number, taken from } \\
\text { Table } 4 \text {. }\end{array}$} & 1 & $\begin{array}{l}\text { 1.015-CSN- } \\
\text { Value }\end{array}$ & $\begin{array}{l}\text { ReturnResult } \\
( \\
\text { Result(Pass) } \\
\text { ) }\end{array}$ & & $\begin{array}{l}\mathrm{M} \uparrow- \\
\text { InfoI }(1.015 . \mathrm{C} \\
\mathrm{SN})\end{array}$ & & & & B \\
\hline & & & 2 & $\begin{array}{l}\text { 1.015-CSN- } \\
\text { Value- } \\
\text { Dependent }\end{array}$ & $\begin{array}{l}\text { IfThenElseResult } \\
( \\
\mathrm{EQ}(\{\operatorname{InfoI}(1.015 . \mathrm{CSI})\}, \operatorname{Int}(0)), \\
\mathrm{EQ}(\{\operatorname{InfoI}(1.015 . \mathrm{CSN})\}, \operatorname{Str}(\mathrm{ASCII})), \\
\text { IfThenElseResult } \\
( \\
\mathrm{EQ}(\{\operatorname{InfoI}(1.015 . \mathrm{CSI})\}, \operatorname{Int}(1)),\end{array}$ & & $\begin{array}{c}\mathrm{M} \uparrow- \\
\text { InfoI }(1.015 . \mathrm{C} \\
\mathrm{SN})\end{array}$ & & & & $\mathrm{X}$ \\
\hline
\end{tabular}




\begin{tabular}{|c|c|c|c|c|c|c|c|c|c|c|c|}
\hline Req. \# - ID & $\begin{array}{l}\text { Ref. in } \\
\text { Base } \\
\text { Std. }\end{array}$ & $\begin{array}{c}\text { Requirement } \\
\text { Summary }\end{array}$ & $\begin{array}{l}\text { L } \\
\text { e } \\
\text { v } \\
\text { e } \\
\text { l }\end{array}$ & $\begin{array}{l}\text { Assertion } \\
\text { ID }\end{array}$ & $\begin{array}{c}\text { Test } \\
\text { Assertion }\end{array}$ & $\begin{array}{l}\mathbf{N} \\
\mathbf{o} \\
\mathbf{t} \\
\mathrm{e} \\
\mathrm{S}\end{array}$ & $\begin{array}{c}\text { Imp. } \\
\text { Required }\end{array}$ & $\begin{array}{c}\text { Imp. } \\
\text { Support }\end{array}$ & $\begin{array}{c}\text { Supporte } \\
\text { d Range }\end{array}$ & $\begin{array}{c}\text { Test } \\
\text { Result }\end{array}$ & $\begin{array}{l}\mathbf{E} \\
\mathbf{n} \\
\mathbf{c} \\
\text {. }\end{array}$ \\
\hline \multicolumn{12}{|c|}{ Record Type-1: Transaction information record } \\
\hline & & & & & $\begin{array}{l}\mathrm{EQ}(\{\operatorname{InfoI}(1.015 . \mathrm{CSN})\}, \operatorname{Str}(8-\text { bit ASCII })) \\
\text { IfThenElseResult } \\
( \\
\mathrm{EQ}(\{\operatorname{InfoI}(1.015 . \mathrm{CSI})\}, \operatorname{Int}(2)), \\
\mathrm{EQ}(\{\operatorname{InfoI}(1.015 . \mathrm{CSN})\}, \operatorname{Str}(8 \mathrm{UTF}-16)), \\
\text { IfThenElseResult } \\
( \\
\mathrm{EQ}(\{\operatorname{InfoI}(1.015 . \mathrm{CSI})\}, \operatorname{Int}(3)), \\
\mathrm{EQ}(\{\operatorname{InfoI}(1.015 . \mathrm{CSN})\}, \operatorname{Str}(8 \mathrm{UTF}-8)), \\
\text { IfThenElseResult } \\
( \\
\mathrm{EQ}(\{\operatorname{InfoI}(1.015 . \mathrm{CSI})\}, \operatorname{Int}(4)), \\
\mathrm{EQ}(\{\operatorname{InfoI}(1.015 . \mathrm{CSN})\}, \operatorname{Str}(8 \mathrm{UTF}-32)), \\
\operatorname{ReturnResult} \\
( \\
\operatorname{Result}(\operatorname{Pass})))))))\end{array}$ & & & & & & \\
\hline $\begin{array}{l}\text { RT1.78 - Fie } \\
\text { Id: } 1.015- \\
\text { CSN- } \\
\text { CharType }\end{array}$ & $\begin{array}{c}8.1 \\
\text { Table 22, }\end{array}$ & $\begin{array}{l}\text { Section } 8.1 \text { and Table } 22 \text { specify the } \\
\text { Character Type for each field. } \\
\text { Numeric values shall not contain leading } \\
\text { zeros unless indicated by the standard text. } \\
\text { Leading zeros are allowed for } 1.002,1.011 \text {, } \\
1.012,99.100 \text {, and } 99.101 \text {. Any dates may } \\
\text { also contain leading zeros. }\end{array}$ & 1 & $\begin{array}{l}\text { 1.015-CSN- } \\
\text { CharType }\end{array}$ & $\begin{array}{l}\text { SubSet } \\
( \\
\text { Chars( }\{\text { InfoI }(1.015 . \mathrm{CSN})\}) \text {, } \\
\text { CharAsciiPrintable } \\
)\end{array}$ & & $\begin{array}{l}\mathrm{M} \uparrow- \\
\text { InfoI }(1.015 . \mathrm{C} \\
\mathrm{SN})\end{array}$ & & & & B \\
\hline $\begin{array}{l}\text { RT1.79 - Fie } \\
\text { ld: } 1.015- \\
\text { CSN- } \\
\text { CharCount }\end{array}$ & Table 22 & $\begin{array}{l}\text { Table } 22 \text { specifies the character count for } \\
\text { each field. }\end{array}$ & 1 & $\begin{array}{l}\text { 1.015-CSN- } \\
\text { CharCount }\end{array}$ & $\begin{array}{l}\text { MO } \\
\text { Count(Chars(\{InfoI(1.015.CSN })\}) \text {, } \\
\text { Set-Int([1 to } 16]) \\
)\end{array}$ & & $\begin{array}{c}\mathrm{M} \uparrow- \\
\text { InfoI(1.015.C } \\
\mathrm{SN})\end{array}$ & & & & B \\
\hline $\begin{array}{l}\text { RT1.80 - Fie } \\
\text { Id: 1.015- } \\
\text { CSV-Value }\end{array}$ & $\begin{array}{l}\text { 8.1.15, } \\
\text { Table 22, } \\
\text { Table } 4\end{array}$ & $\begin{array}{l}\text { The optional third information item } \\
\text { (character encoding version / CSV) is the } \\
\text { specific version of the character encoding } \\
\text { used. In the case of the use of UTF- } 8 \text {, the } \\
\text { third optional information item may be } \\
\text { used to hold the specific version used, so } \\
\text { that the display terminal can be switched to } \\
\text { the correct font family. }\end{array}$ & 1 & $\begin{array}{l}\text { 1.015-CSV- } \\
\text { Value }\end{array}$ & $\begin{array}{l}\text { ReturnResult } \\
( \\
\text { Result(Pass) } \\
\text { ) }\end{array}$ & & $\begin{array}{c}\mathrm{O} \uparrow- \\
\text { InfoI }(1.015 . \mathrm{C} \\
\mathrm{SV})\end{array}$ & & & & $\mathrm{B}$ \\
\hline
\end{tabular}




\begin{tabular}{|c|c|c|c|c|c|c|c|c|c|c|c|}
\hline Req. \# - ID & $\begin{array}{l}\text { Ref. in } \\
\text { Base } \\
\text { Std. }\end{array}$ & $\begin{array}{l}\text { Requirement } \\
\text { Summary }\end{array}$ & $\begin{array}{l}\text { L } \\
\text { e } \\
\text { v } \\
\text { e } \\
\text { l }\end{array}$ & $\begin{array}{l}\text { Assertion } \\
\text { ID }\end{array}$ & $\begin{array}{c}\text { Test } \\
\text { Assertion }\end{array}$ & $\begin{array}{l}\mathbf{N} \\
\mathbf{o} \\
\mathbf{t} \\
\mathrm{e} \\
\mathrm{S}\end{array}$ & $\begin{array}{c}\text { Imp. } \\
\text { Required }\end{array}$ & $\begin{array}{c}\text { Imp. } \\
\text { Support }\end{array}$ & $\begin{array}{l}\text { Supporte } \\
\text { d Range }\end{array}$ & $\begin{array}{c}\text { Test } \\
\text { Result }\end{array}$ & $\begin{array}{l}\mathbf{E} \\
\mathbf{n} \\
\mathbf{c}\end{array}$ \\
\hline \multicolumn{12}{|c|}{ Record Type-1: Transaction information record } \\
\hline $\begin{array}{l}\text { RT1.81 - Fie } \\
\text { ld: } 1.015- \\
\text { CSV- } \\
\text { CharType }\end{array}$ & $\begin{array}{c}8.1 \\
\text { Table 22, }\end{array}$ & $\begin{array}{l}\text { Section } 8.1 \text { and Table } 22 \text { specify the } \\
\text { Character Type for each field. } \\
\text { Numeric values shall not contain leading } \\
\text { zeros unless indicated by the standard text. } \\
\text { Leading zeros are allowed for } 1.002,1.011 \text {, } \\
1.012,99.100 \text {, and } 99.101 \text {. Any dates may } \\
\text { also contain leading zeros. }\end{array}$ & 1 & $\begin{array}{l}\text { 1.015-CSV- } \\
\text { CharType }\end{array}$ & $\begin{array}{l}\text { SubSet } \\
( \\
\text { Chars(\{InfoI(1.015.CSV })\}), \\
\text { CharAsciiPrintable } \\
)\end{array}$ & & $\begin{array}{l}\mathrm{O} \uparrow- \\
\text { InfoI }(1.015 . \mathrm{C} \\
\mathrm{SV})\end{array}$ & & & & B \\
\hline $\begin{array}{l}\text { RT1.82 - Fie } \\
\text { Id: } 1.015- \\
\text { CSV- } \\
\text { CharCount }\end{array}$ & Table 22 & $\begin{array}{l}\text { Table } 22 \text { specifies the character count for } \\
\text { each field. }\end{array}$ & 1 & $\begin{array}{l}\text { 1.015-CSV- } \\
\text { CharCount }\end{array}$ & $\begin{array}{l}\text { MO } \\
( \\
\text { Count(Chars(\{InfoI(1.015.CSV)\}), } \\
\text { Set-Int([1 to 16]) }\end{array}$ & & $\begin{array}{c}\mathrm{M} \uparrow- \\
\text { InfoI(1.015.C } \\
\mathrm{SV})\end{array}$ & & & & B \\
\hline \multirow[t]{3}{*}{$\begin{array}{l}\text { RT1.83 - Fie } \\
\text { Id: } 1.016- \\
\text { APS- } \\
\text { FieldStructu } \\
\text { re }\end{array}$} & \multirow[t]{3}{*}{$\begin{array}{l}\text { Table 22, } \\
\text { Annex B, } \\
\text { Annex G }\end{array}$} & \multirow{3}{*}{$\begin{array}{l}\text { Table } 22 \text { specifies which fields contain } \\
\text { subfields and information items as well as } \\
\text { the number of occurrences permitted. } \\
\text { A field contains a minimum of one } \\
\text { subfield which contains a minimum of one } \\
\text { information item. }\end{array}$} & 1 & $\begin{array}{l}\text { 1.016-APS- } \\
\text { SubfieldCou } \\
\text { nt }\end{array}$ & $\begin{array}{l}\text { MO } \\
\text { Count(SubFldsIn(Fld(1.016))), } \\
\text { Set-Int([1 to 99]) }\end{array}$ & & O-Fld(1.016) & & & & $\mathrm{T}$ \\
\hline & & & 1 & $\begin{array}{l}\text { 1.016-APS- } \\
\text { InfoItemCou } \\
\mathrm{nt}\end{array}$ & $\begin{array}{l}\text { EQ } \\
\text { Count(InfoItemsIn(SubFld(1.016))), } \\
\text { Int(3) }\end{array}$ & & O-Fld(1.016) & & & & $\mathrm{T}$ \\
\hline & & & 1 & $\begin{array}{l}\text { 1.016-APS- } \\
\text { InfoItemStru } \\
\text { cture }\end{array}$ & $\begin{array}{l}\text { InfoItemsHaveData } \\
( \\
\text { SubFld(1.016), } \\
\text { Set-Int([1,2,3]) } \\
\text { ) }\end{array}$ & & O-Fld(1.016) & & & & $\mathrm{T}$ \\
\hline $\begin{array}{c}\text { RT1.84 - Fie } \\
\text { Id: 1.016- } \\
\text { APO-Value }\end{array}$ & $\begin{array}{l}\text { 8.1.16, } \\
\text { Table } 22\end{array}$ & $\begin{array}{l}\text { The first information item (application } \\
\text { profile organization / APO) will uniquely } \\
\text { identify the agency or entity responsible } \\
\text { for the specification. }\end{array}$ & 1 & $\begin{array}{l}\text { 1.016-APO- } \\
\text { Value }\end{array}$ & $\begin{array}{l}\text { ReturnResult } \\
( \\
\text { Result(Pass) } \\
\text { ) }\end{array}$ & & $\begin{array}{l}\mathrm{M} \uparrow- \\
\text { InfoI }(1.016 . \mathrm{A} \\
\mathrm{PO})\end{array}$ & & & & B \\
\hline $\begin{array}{l}\text { RT1.85 - Fie } \\
\text { ld: } 1.016- \\
\text { APO- } \\
\text { CharType }\end{array}$ & $\begin{array}{c}8.1 \\
\text { Table 22, }\end{array}$ & $\begin{array}{l}\text { Section } 8.1 \text { and Table } 22 \text { specify the } \\
\text { Character Type for each field. } \\
\text { Numeric values shall not contain leading } \\
\text { zeros unless indicated by the standard text. } \\
\text { Leading zeros are allowed for } 1.002,1.011 \text {, } \\
1.012,99.100 \text {, and } 99.101 \text {. Any dates may }\end{array}$ & 1 & $\begin{array}{l}\text { 1.016-APO- } \\
\text { CharType }\end{array}$ & $\begin{array}{l}\text { SubSet } \\
( \\
\text { Chars( }\{\text { InfoI }(1.016 . A P O)\}), \\
\text { CharAsciiPrintable } \\
\text { ) }\end{array}$ & & $\begin{array}{c}\mathrm{M} \uparrow- \\
\text { InfoI(1.016.A } \\
\text { PO) }\end{array}$ & & & & B \\
\hline
\end{tabular}




\begin{tabular}{|c|c|c|c|c|c|c|c|c|c|c|c|}
\hline Req. \# - ID & $\begin{array}{l}\text { Ref. in } \\
\text { Base } \\
\text { Std. }\end{array}$ & $\begin{array}{l}\text { Requirement } \\
\text { Summary }\end{array}$ & $\begin{array}{l}\text { L } \\
\text { e } \\
\text { v } \\
\text { e } \\
\text { l }\end{array}$ & $\begin{array}{l}\text { Assertion } \\
\text { ID }\end{array}$ & $\begin{array}{c}\text { Test } \\
\text { Assertion }\end{array}$ & $\begin{array}{l}\mathbf{N} \\
\mathbf{o} \\
\mathbf{t} \\
\mathbf{e} \\
\mathbf{S}\end{array}$ & $\begin{array}{l}\text { Imp. } \\
\text { Required }\end{array}$ & $\begin{array}{l}\text { Imp. } \\
\text { Support }\end{array}$ & $\begin{array}{l}\text { Supporte } \\
\text { d Range }\end{array}$ & $\begin{array}{l}\text { Test } \\
\text { Result }\end{array}$ & $\begin{array}{l}\mathbf{E} \\
\mathbf{n} \\
\mathbf{c} \\
\text {. }\end{array}$ \\
\hline \multicolumn{12}{|c|}{ Record Type-1: Transaction information record } \\
\hline & & also contain leading zeros. & & & & & & & & & \\
\hline $\begin{array}{l}\text { RT1.86 - Fie } \\
\text { Id: 1.016- } \\
\text { APO- } \\
\text { CharCount }\end{array}$ & Table 22 & $\begin{array}{l}\text { Table } 22 \text { specifies the character count for } \\
\text { each field. }\end{array}$ & 1 & $\begin{array}{l}\text { 1.016-APO - } \\
\text { CharCount }\end{array}$ & $\begin{array}{l}\text { GTE } \\
( \\
\text { Count(Chars( }(\text { InfoI }(1.016 . \mathrm{APO}\}), \\
\operatorname{Int}(1)\end{array}$ & & $\begin{array}{c}\mathrm{M} \uparrow- \\
\text { InfoI(1.016.A } \\
\text { PO) }\end{array}$ & & & & B \\
\hline $\begin{array}{l}\text { RT1.87 - Fie } \\
\text { Id: } 1.016- \\
\text { APN-Value }\end{array}$ & $\begin{array}{l}8.1 .16 \\
\text { Table } 22\end{array}$ & $\begin{array}{l}\text { The second information item (application } \\
\text { profile name / APN) shall contain the name } \\
\text { of the specification. }\end{array}$ & 1 & $\begin{array}{l}\text { 1.016-APN- } \\
\text { Value }\end{array}$ & $\begin{array}{l}\text { ReturnResult } \\
( \\
\text { Result(Pass) } \\
\text { ) }\end{array}$ & & $\begin{array}{c}\mathrm{M} \uparrow- \\
\text { InfoI }(1.016 . \mathrm{A} \\
\mathrm{PN})\end{array}$ & & & & B \\
\hline $\begin{array}{l}\text { RT1.88 - Fie } \\
\text { ld: } 1.016- \\
\text { APN- } \\
\text { CharType }\end{array}$ & $\begin{array}{c}8.1 \\
\text { Table } 22,\end{array}$ & $\begin{array}{l}\text { Section } 8.1 \text { and Table } 22 \text { specify the } \\
\text { Character Type for each field. } \\
\text { Numeric values shall not contain leading } \\
\text { zeros unless indicated by the standard text. } \\
\text { Leading zeros are allowed for } 1.002,1.011 \text {, } \\
1.012,99.100 \text {, and } 99.101 \text {. Any dates may } \\
\text { also contain leading zeros. }\end{array}$ & 1 & $\begin{array}{l}\text { 1.016-APN- } \\
\text { CharType }\end{array}$ & $\begin{array}{l}\text { SubSet } \\
(\text { Chars }(\{\operatorname{InfoI}(1.016 . \mathrm{APN})\}), \\
\text { CharAsciiPrintable } \\
\text { ) }\end{array}$ & & $\begin{array}{c}\mathrm{M} \uparrow- \\
\text { InfoI }(1.016 . \mathrm{A} \\
\mathrm{PN})\end{array}$ & & & & B \\
\hline $\begin{array}{l}\text { RT1.89- Fie } \\
\text { Id: } 1.016- \\
\text { APN- } \\
\text { CharCount }\end{array}$ & Table 22 & $\begin{array}{l}\text { Table } 22 \text { specifies the character count for } \\
\text { each field. }\end{array}$ & 1 & $\begin{array}{l}\text { 1.016-APN - } \\
\text { CharCount }\end{array}$ & $\begin{array}{l}\text { GTE } \\
( \\
\text { Count(Chars }(\{\operatorname{InfoI}(1.016 . \mathrm{APN}\}), \\
\operatorname{Int}(1) \\
)\end{array}$ & & $\begin{array}{c}\mathrm{M} \uparrow- \\
\text { InfoI }(1.016 . \mathrm{A} \\
\mathrm{PN})\end{array}$ & & & & B \\
\hline $\begin{array}{l}\text { RT1.90 - Fie } \\
\text { Id: 1.016- } \\
\text { APV-Value }\end{array}$ & $\begin{array}{l}8.1 .16 \\
\text { Table } 22\end{array}$ & $\begin{array}{l}\text { The third information item (application } \\
\text { profile version number / APV) shall } \\
\text { contain the specific version of the } \\
\text { specification. }\end{array}$ & 1 & $\begin{array}{l}\text { 1.016-APV- } \\
\text { Value }\end{array}$ & $\begin{array}{l}\text { ReturnResult } \\
( \\
\text { Result(Pass) } \\
\text { ) }\end{array}$ & & $\begin{array}{c}\mathrm{M} \uparrow- \\
\text { InfoI }(1.016 . \mathrm{A} \\
\mathrm{PV})\end{array}$ & & & & B \\
\hline $\begin{array}{l}\text { RT1.91 - Fie } \\
\text { Id: } 1.016- \\
\text { APV- } \\
\text { CharType }\end{array}$ & $\begin{array}{c}8.1 \\
\text { Table } 22,\end{array}$ & $\begin{array}{l}\text { Section } 8.1 \text { and Table } 22 \text { specify the } \\
\text { Character Type for each field. } \\
\text { Numeric values shall not contain leading } \\
\text { zeros unless indicated by the standard text. } \\
\text { Leading zeros are allowed for } 1.002,1.011 \text {, } \\
1.012,99.100 \text {, and } 99.101 \text {. Any dates may } \\
\text { also contain leading zeros. }\end{array}$ & 1 & $\begin{array}{l}\text { 1.016-APV- } \\
\text { CharType }\end{array}$ & $\begin{array}{l}\text { SubSet } \\
\text { Chars( }\{\text { InfoI(1.016.APV })\}), \\
\text { CharAsciiPrintable } \\
\text { ) }\end{array}$ & & $\begin{array}{c}\mathrm{M} \uparrow- \\
\text { InfoI }(1.016 . \mathrm{A} \\
\mathrm{PV})\end{array}$ & & & & B \\
\hline $\begin{array}{l}\text { RT1.92 - Fie } \\
\text { Id: 1.016- } \\
\text { APV- } \\
\text { CharCount }\end{array}$ & Table 22 & $\begin{array}{l}\text { Table } 22 \text { specifies the character count for } \\
\text { each field. }\end{array}$ & 1 & $\begin{array}{l}\text { 1.016-APV - } \\
\text { CharCount }\end{array}$ & $\begin{array}{l}\text { GTE } \\
( \\
\text { Count(Chars }(\{\operatorname{InfoI}(1.016 . \mathrm{APV}\}), \\
\operatorname{Int}(1)\end{array}$ & & $\begin{array}{c}\mathrm{M} \uparrow- \\
\text { InfoI }(1.016 . \mathrm{A} \\
\mathrm{PV})\end{array}$ & & & & B \\
\hline $\begin{array}{l}\text { RT1.93 - Fie } \\
\text { Id: } 1.016-\end{array}$ & 8.1 .16 & $\begin{array}{l}\text { If multiple Application Profile } \\
\text { Specifications are included in this field, the }\end{array}$ & 3 & $\begin{array}{l}\text { 1.016-APS } \\
\text { Compliance }\end{array}$ & ReturnResult & & O-Fld(1.016) & & & & B \\
\hline
\end{tabular}




\begin{tabular}{|c|c|c|c|c|c|c|c|c|c|c|c|}
\hline Req. \# - ID & $\begin{array}{l}\text { Ref. in } \\
\text { Base } \\
\text { Std. }\end{array}$ & $\begin{array}{l}\text { Requirement } \\
\text { Summary }\end{array}$ & $\begin{array}{l}\text { L } \\
\text { e } \\
\text { v } \\
\text { e } \\
\text { l }\end{array}$ & $\begin{array}{l}\text { Assertion } \\
\text { ID }\end{array}$ & $\begin{array}{c}\text { Test } \\
\text { Assertion }\end{array}$ & $\begin{array}{l}\mathbf{N} \\
\mathbf{o} \\
\mathbf{t} \\
\mathbf{e} \\
\mathbf{S}\end{array}$ & $\begin{array}{l}\text { Imp. } \\
\text { Required }\end{array}$ & $\begin{array}{l}\text { Imp. } \\
\text { Support }\end{array}$ & $\begin{array}{l}\text { Supporte } \\
\text { d Range }\end{array}$ & $\begin{array}{c}\text { Test } \\
\text { Result }\end{array}$ & $\begin{array}{l}\mathbf{E} \\
\mathbf{n} \\
\mathbf{c} \\
\text {. }\end{array}$ \\
\hline \multicolumn{12}{|c|}{ Record Type-1: Transaction information record } \\
\hline $\begin{array}{c}\text { APS- } \\
\text { Compliance }\end{array}$ & & $\begin{array}{l}\text { specifications must be compatible with } \\
\text { each other: this transaction must be in } \\
\text { compliance with all of the cited } \\
\text { specifications. See Section } 6 \text {. }\end{array}$ & & & $\begin{array}{l}\text { Result } \\
\text { (Warning(Untested Level 3-Application Profiles } \\
\text { external references are outside of the scope of } \\
\text { conformance testing to the base standard.)) } \\
\text { ) }\end{array}$ & & & & & & \\
\hline \multirow[t]{3}{*}{$\begin{array}{l}\text { RT1.94 - Fie } \\
\text { Id: } 1.017- \\
\text { ANM- } \\
\text { FieldStructu } \\
\quad \text { re }\end{array}$} & \multirow[t]{3}{*}{$\begin{array}{l}\text { Table 22, } \\
\text { Annex B, } \\
\text { Annex G }\end{array}$} & \multirow{3}{*}{$\begin{array}{l}\text { Table } 22 \text { specifies which fields contain } \\
\text { subfields and information items as well as } \\
\text { the number of occurrences permitted. } \\
\text { A field contains a minimum of one } \\
\text { subfield which contains a minimum of one } \\
\text { information item. }\end{array}$} & 1 & $\begin{array}{l}\text { 1.017-ANM- } \\
\text { SubfieldCou } \\
\text { nt }\end{array}$ & $\begin{array}{l}\text { EQ } \\
( \\
\text { Count(SubFldsIn(Fld(1.017))), } \\
\text { Int(1) }\end{array}$ & & O-Fld(1.017) & & & & $\mathrm{T}$ \\
\hline & & & 1 & $\begin{array}{l}\text { 1.017-ANM- } \\
\text { InfoItemCou } \\
\text { nt }\end{array}$ & $\begin{array}{l}\text { LTE } \\
\text { Count(InfoItemsIn(SubFld(1.017.1))), } \\
\text { Int(2) }\end{array}$ & & O-Fld(1.017) & & & & $\mathrm{T}$ \\
\hline & & & 1 & $\begin{array}{l}\text { 1.017-ANM- } \\
\text { InfoItemCou } \\
\text { nt }\end{array}$ & $\begin{array}{l}\text { ReturnResult } \\
\text { Result(Pass(All Information Items are optional } \\
\text { for this field.)) } \\
\text { ) }\end{array}$ & & O-Fld(1.017) & & & & $\mathrm{T}$ \\
\hline $\begin{array}{l}\text { RT1.95 - Fie } \\
\text { ld:1.017- } \\
\text { DAN-Value }\end{array}$ & 8.1 .17 & $\begin{array}{l}\text { Both information items are alphanumeric } \\
\text { and can have any special characters in the } \\
\text { names. }\end{array}$ & 1 & $\begin{array}{l}\text { 1.017-DAN- } \\
\text { Value }\end{array}$ & $\begin{array}{l}\text { ReturnResult } \\
\text { Result(Pass) } \\
\text { ) }\end{array}$ & & $\begin{array}{l}\mathrm{O} \uparrow- \\
\text { InfoI }(1.017 . \mathrm{D} \\
\mathrm{AN})\end{array}$ & & & & B \\
\hline $\begin{array}{l}\text { RT1.96 - Fie } \\
\text { Id:1.017- } \\
\text { DAN- } \\
\text { CharType }\end{array}$ & $\begin{array}{c}8.1 \\
\text { Table 22, }\end{array}$ & $\begin{array}{l}\text { Section } 8.1 \text { and Table } 22 \text { specify the } \\
\text { Character Type for each field. } \\
\text { Numeric values shall not contain leading } \\
\text { zeros unless indicated by the standard text. } \\
\text { Leading zeros are allowed for } 1.002,1.011 \text {, } \\
1.012,99.100 \text {, and } 99.101 \text {. Any dates may } \\
\text { also contain leading zeros. }\end{array}$ & 1 & $\begin{array}{l}\text { 1.017-DAN- } \\
\text { CharType }\end{array}$ & $\begin{array}{l}\text { SubSet } \\
\text { Chars(\{InfoI(1.017.DAN })\}), \\
\text { CharAssiiPrintable } \\
\text { ) }\end{array}$ & & $\begin{array}{l}\mathrm{O} \uparrow- \\
\text { InfoI }(1.017 . \mathrm{D} \\
\mathrm{AN})\end{array}$ & & & & B \\
\hline $\begin{array}{l}\text { RT1.97 - Fie } \\
\text { Id:1.017- } \\
\text { DAN- } \\
\text { CharCount }\end{array}$ & Table 22 & $\begin{array}{l}\text { Table } 22 \text { specifies the character count for } \\
\text { each field. }\end{array}$ & 1 & $\begin{array}{l}\text { 1.017-DAN } \\
\text {-CharCount }\end{array}$ & $\begin{array}{l}\text { GTE } \\
\text { Count(Chars(\{InfoI(1.017.DAN }\}), \\
\text { Int(1) }\end{array}$ & & $\begin{array}{l}\mathrm{O} \uparrow- \\
\text { InfoI }(1.017 . \mathrm{D} \\
\text { AN) }\end{array}$ & & & & B \\
\hline $\begin{array}{l}\text { RT1.98 - Fie } \\
\text { Id:1.017- } \\
\text { OAN-Value }\end{array}$ & 8.1 .17 & $\begin{array}{l}\text { Both information items are alphanumeric } \\
\text { and can have any special characters in the } \\
\text { names. }\end{array}$ & 1 & $\begin{array}{l}1.017- \\
\text { OAN-Value }\end{array}$ & $\begin{array}{l}\text { ReturnResult } \\
( \\
\text { Result(Pass) }\end{array}$ & & $\begin{array}{l}\mathrm{O} \uparrow- \\
\text { InfoI }(1.017 . \mathrm{O} \\
\text { AN })\end{array}$ & & & & B \\
\hline RT1.99 - Fie & 8.1 & Section 8.1 and Table 22 specify the & 1 & 1.017-OAN- & SubSet & & $\mathrm{O} \uparrow-$ & & & & B \\
\hline
\end{tabular}




\begin{tabular}{|c|c|c|c|c|c|c|c|c|c|c|c|}
\hline Req. \# - ID & $\begin{array}{l}\text { Ref. in } \\
\text { Base } \\
\text { Std. }\end{array}$ & $\begin{array}{l}\text { Requirement } \\
\text { Summary }\end{array}$ & $\begin{array}{l}\text { L } \\
\text { e } \\
\text { v } \\
\text { e } \\
\text { l }\end{array}$ & $\begin{array}{l}\text { Assertion } \\
\text { ID }\end{array}$ & $\begin{array}{c}\text { Test } \\
\text { Assertion }\end{array}$ & $\begin{array}{l}\mathbf{N} \\
\mathbf{o} \\
\mathbf{t} \\
\mathrm{e} \\
\mathrm{S}\end{array}$ & $\begin{array}{c}\text { Imp. } \\
\text { Required }\end{array}$ & $\begin{array}{c}\text { Imp. } \\
\text { Support }\end{array}$ & $\begin{array}{l}\text { Supporte } \\
\text { d Range }\end{array}$ & $\begin{array}{c}\text { Test } \\
\text { Result }\end{array}$ & $\begin{array}{l}\mathbf{E} \\
\mathbf{n} \\
\mathbf{c} \\
\text {. }\end{array}$ \\
\hline \multicolumn{12}{|c|}{ Record Type-1: Transaction information record } \\
\hline $\begin{array}{l}\text { Id:1.017- } \\
\text { OAN- } \\
\text { CharType }\end{array}$ & Table 22, & $\begin{array}{l}\text { Character Type for each field. } \\
\text { Numeric values shall not contain leading } \\
\text { zeros unless indicated by the standard text. } \\
\text { Leading zeros are allowed for } 1.002,1.011 \text {, } \\
1.012,99.100 \text {, and } 99.101 \text {. Any dates may } \\
\text { also contain leading zeros. }\end{array}$ & & CharType & $\begin{array}{l}\text { Chars( }\{\text { InfoI(1.017.OAN })\}), \\
\text { CharAsciiPrintable } \\
\text { ) }\end{array}$ & & $\begin{array}{c}\text { InfoI }(1.017 .0 \\
\text { AN) }\end{array}$ & & & & \\
\hline $\begin{array}{l}\text { RT1.100 - Fi } \\
\text { eld:1.017- } \\
\text { OAN- } \\
\text { CharCount }\end{array}$ & Table 22 & $\begin{array}{l}\text { Table } 22 \text { specifies the character count for } \\
\text { each field. }\end{array}$ & 1 & $\begin{array}{l}\text { 1.017-OAN } \\
\text {-CharCount }\end{array}$ & $\begin{array}{l}\text { GTE } \\
( \\
\text { Count }(\operatorname{Chars}(\{\operatorname{InfoI}(1.017 . \mathrm{OAN}\}), \\
\operatorname{Int}(1)\end{array}$ & & $\begin{array}{c}\mathrm{O} \uparrow- \\
\text { InfoI }(1.017 . \mathrm{O} \\
\mathrm{AN})\end{array}$ & & & & $\mathrm{B}$ \\
\hline \multirow[t]{2}{*}{$\begin{array}{l}\text { RT1.101 - Fi } \\
\text { eld: } 1.018- \\
\text { GNS- } \\
\text { FieldStructu } \\
\quad \text { re }\end{array}$} & \multirow[t]{2}{*}{$\begin{array}{l}\text { Table 22, } \\
\text { Annex B, } \\
\text { Annex G }\end{array}$} & \multirow{2}{*}{$\begin{array}{l}\text { Table } 22 \text { specifies which fields contain } \\
\text { subfields and information items as well as } \\
\text { the number of occurrences permitted. } \\
\text { A field contains a minimum of one } \\
\text { subfield which contains a minimum of one } \\
\text { information item. }\end{array}$} & 1 & $\begin{array}{l}\text { 1.018-GNS- } \\
\text { SubfieldCou } \\
\text { nt }\end{array}$ & $\begin{array}{l}\text { EQ } \\
( \\
\text { Count(SubFldsIn(Fld(1.018))), } \\
\text { Int(1) }\end{array}$ & & O-Fld(1.018) & & & & $\mathrm{T}$ \\
\hline & & & 1 & $\begin{array}{l}\text { 1.018-GNS- } \\
\text { InfoItemCou } \\
\mathrm{nt}\end{array}$ & $\begin{array}{l}\text { EQ } \\
( \\
\text { Count(InfoItemsIn(SubFld(1.018.1))), } \\
\text { Int(1) }\end{array}$ & & O-Fld(1.018) & & & & $\mathrm{T}$ \\
\hline $\begin{array}{l}\text { RT1.102 - Fi } \\
\text { eld: } 1.018- \\
\text { GNS-Value }\end{array}$ & 8.1 .18 & $\begin{array}{l}\text { This optional field is used if the transaction } \\
\text { uses GENC in lieu of ISO } 3166-1 \\
\text { as a code set for country code } \\
\text { specifications. ISO } 3166-1 \text { is the default } \\
\text { country code set } \\
\text { used for the transaction when this field is } \\
\text { not contained in Record Type-1. The } \\
\text { values for this field are: ISO, GENC }\end{array}$ & 1 & $\begin{array}{l}\text { 1.018-GNS- } \\
\text { Value }\end{array}$ & $\begin{array}{l}\text { MO } \\
\{\text { Fld }(1.018)\} \\
\text { Set-Str([ISO, GENC] })\end{array}$ & & O-Fld(1.018) & & & & B \\
\hline $\begin{array}{l}\text { RT1.103 - Fi } \\
\text { eld: } 1.018- \\
\text { GNS- } \\
\text { CharType }\end{array}$ & $\begin{array}{c}8.1 \\
\text { Table 22, }\end{array}$ & $\begin{array}{l}\text { Section } 8.1 \text { and Table } 22 \text { specify the } \\
\text { Character Type for each field. } \\
\text { Numeric values shall not contain leading } \\
\text { zeros unless indicated by the standard text. } \\
\text { Leading zeros are allowed for } 1.002,1.011 \text {, } \\
1.012,99.100 \text {, and } 99.101 \text {. Any dates may } \\
\text { also contain leading zeros. }\end{array}$ & 1 & $\begin{array}{l}\text { 1.018-GNS- } \\
\text { CharType }\end{array}$ & $\begin{array}{l}\text { SubSet } \\
( \\
\text { Chars(\{Fld(1.018.GNS })\}), \\
\text { CharAlpha } \\
\text { ) }\end{array}$ & & O-Fld(1.018) & & & & B \\
\hline $\begin{array}{l}\text { RT1.104 - Fi } \\
\text { eld: } 1.018- \\
\text { GNS- } \\
\text { CharCount }\end{array}$ & Table 22 & $\begin{array}{l}\text { Table } 22 \text { specifies the character count for } \\
\text { each field. }\end{array}$ & 1 & $\begin{array}{l}\text { 1.018-GNS- } \\
\text { CharType }\end{array}$ & $\begin{array}{l}\text { MO } \\
( \\
\text { Count }(\operatorname{Chars}(\{\operatorname{Fld}(1.018\})), \\
\text { Set-Int }([3,4])\end{array}$ & & O-Fld(1.018) & & & & B \\
\hline
\end{tabular}




\begin{tabular}{|c|c|c|c|c|c|c|c|c|c|c|c|}
\hline Req. \# - ID & $\begin{array}{c}\text { Ref. in } \\
\text { Base } \\
\text { Std. }\end{array}$ & $\begin{array}{l}\text { Requirement } \\
\text { Summary }\end{array}$ & $\begin{array}{l}\mathrm{L} \\
\mathrm{e} \\
\mathrm{v} \\
\mathrm{e} \\
\mathrm{l}\end{array}$ & $\begin{array}{l}\text { Assertion } \\
\text { ID }\end{array}$ & $\begin{array}{c}\text { Test } \\
\text { Assertion }\end{array}$ & $\begin{array}{l}\mathbf{N} \\
\mathbf{0} \\
\mathbf{t} \\
\mathbf{e} \\
\mathbf{S}\end{array}$ & $\begin{array}{c}\text { Imp. } \\
\text { Required }\end{array}$ & $\begin{array}{c}\text { Imp. } \\
\text { Support }\end{array}$ & $\begin{array}{l}\text { Supporte } \\
\text { d Range }\end{array}$ & $\begin{array}{c}\text { Test } \\
\text { Result }\end{array}$ & $\begin{array}{l}\mathbf{E} \\
\mathbf{n} \\
\mathbf{c} \\
\text {. }\end{array}$ \\
\hline
\end{tabular}

\section{Annex D: Test Notes and Test Exceptions}

This Annex defines test notes and test exceptions that apply to requirements and assertions documented in Annex C as well as test notes and exceptions for those requirements which may be released in separate publications. As these test notes and requirements may need to be updated as additional requirements are documented, the test notes and test exceptions are included as an external reference. The test notes and exceptions will be made available at: http://www.nist.gov/itl/csd/biometrics/biocta download.cfm.

\section{Acknowledgements}

This publication was the result of work was sponsored, in part, by the Department of Homeland Security/Office of Biometric Identity Management (OBIM). Christofer J. McGinnis, from IDTP, a NIST/ITL grantee, developed most of the test assertions documented in this publication. 